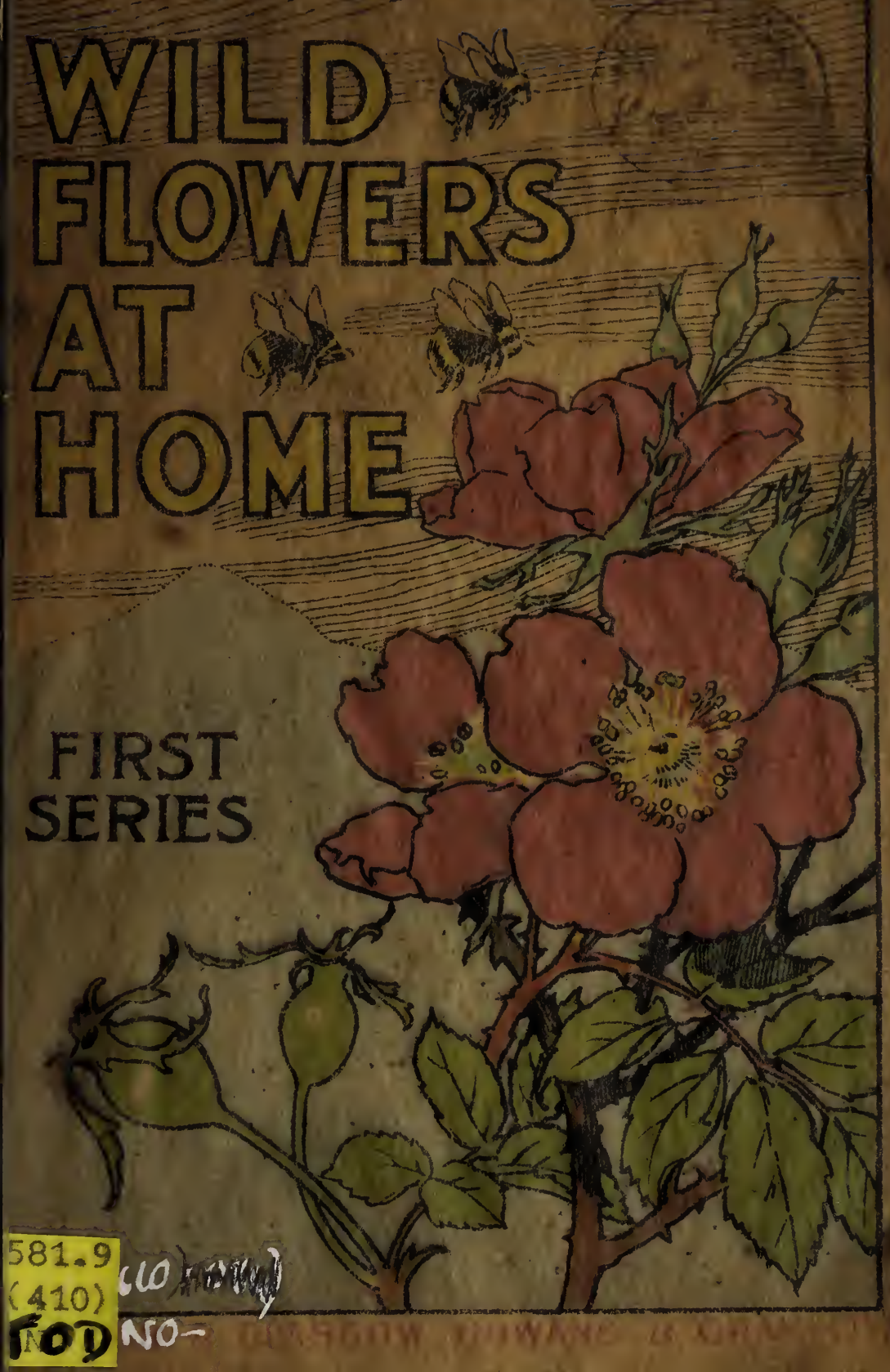


a. B. Jackson.

Sep.1906.

$$
\begin{aligned}
& 581.9(400) \mathrm{H} \text { ) } \\
& \text { ANO- }
\end{aligned}
$$




\section{3.

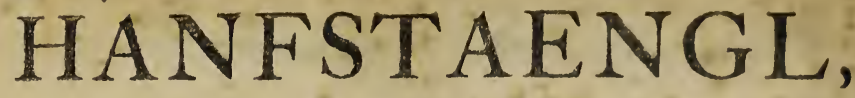

FINE AR'T $\ldots$

REPRODUCER,

I6 PALL MALL EAST,

LonDON, S.W.

A LL the Illustrations in GOWANS'S ART BOOKS were taken from Photographs by Franz Hanfstaengl, and the Publishers, Messrs. Gowans \& Gray, write:-

"We have been congratulated on all hands on the beauty of the illustrations in our little Art Books, and we cannot refrain from stating that we consider the principal credit is due to rouefor your magnificent photographs, without which the fine achievements of the engravers and printers would have been unavailing."

HANFSTAENQL'S PHOTOORAPHIC REPHODUCTIONS are Published in many difrerent sizes, at Prices ranging from 18 , to 6 cuineas:

LISTS AND PARTICULARS ON APPLICATION. 
UNIFORM WITH OUR "POCKET ANTHOLOGIES."

\title{
The Hundred Best Poems
}

\section{(Lyrical)}

\section{in the Latin Language.}

Selected by J. W. MACKAIL, M.A., LL.D., Translator of Homer's 'Odyssey, Virgil's 'Georgics, etc. Author of 'Latin Literature.

THz Publishers consider themselves very fortunate In having secured Dr. Mackail as compiler of this little selection. In a prettily got up volume of handy size will be found the very flower of Latin lyrical poetry. A delightful pocket companion for the classical scholar, the book will also be found of the greatest value to teachers for awakening in the student 2 real love for the best poetry.

\section{Price8,}

\author{
PAPER, 6D. NeT. Cloth, 18. NeT. \\ Leather, 2s. Net. Postage, 1 d.
}

Glasgow : GOWANS \& GRAY, Ltd.

LOndOn: BRIMLEY JOHNSON \& INCE, Ltd. 
Ready AUtumn, 1905.

UNIFORM WITH POCKET ANTHOLOGIES.

\title{
LES CENT
}

\section{MEILLEURS POĖMES \\ (Lyriques)}

\section{de la Langue Française,}

\author{
Choisis par \\ AUGUSTE DORCHAIN.
}

IT would have been difficult to find in France a more competent scholar to make this selection than M. DoRCHAIN, himself a poet of standing, poetical critic to the famous French weekly, Les Annales, and author of L'Art des Vers. The taste displayed in the selection of poems for this Anthology will, the publisher believes, cause it to become a standard book at once.

\section{Price8:}

Paper Cover, 6d. Net. Cloth, 1s. Net, leather, 28. Net. Postage, $1 \mathrm{D}$.

GOWANS \& GRAY, Ltd., Glasgow. BRIMLEY JOHNSON \& INCE, Ltd., 35 Leicester Square, London, W.C. 
Vols. VII., VIII, OF "THE COMPLETE WORKS OZ Cervantes" contain the

\section{Exemplary Novels.}

Translated by NORMAN MACCOLL.

Edited by JAS, FITZMAURICE.KELLY.

\section{IN TWO VOLUMES.}

EAOH 18. Net IN Cloth! 2S. NET IN LEATHER.

THE first perfectly complete and competent English version of these brilliant tales. Points to be noted:-(I) The translation was made from the editio princeps by the late Mr. Norman MacColl, a distinguished Spanish scholar, who also annotated where necessary; (2) Mr. Fitzmaurice-Kelly has written an introduction, which shews a knowledge of the subject which is unequalled at the present time.

The Manchester Guardian says:- "After comparing long passages of it with the original, we feel confident that it cannot be superseded until Spanish scholarship shall have improved its methods. . The book throughout is of a nature to delight the specialist..

Glasgow: GOWANS \& GRAY, Ltd. LOAdOR, BRIMLEY JOHNSON \& INCE, LtA 
Gowans's Nature Books, No. 2

\section{Wild Flowers at Home}

FIRST SERIES 


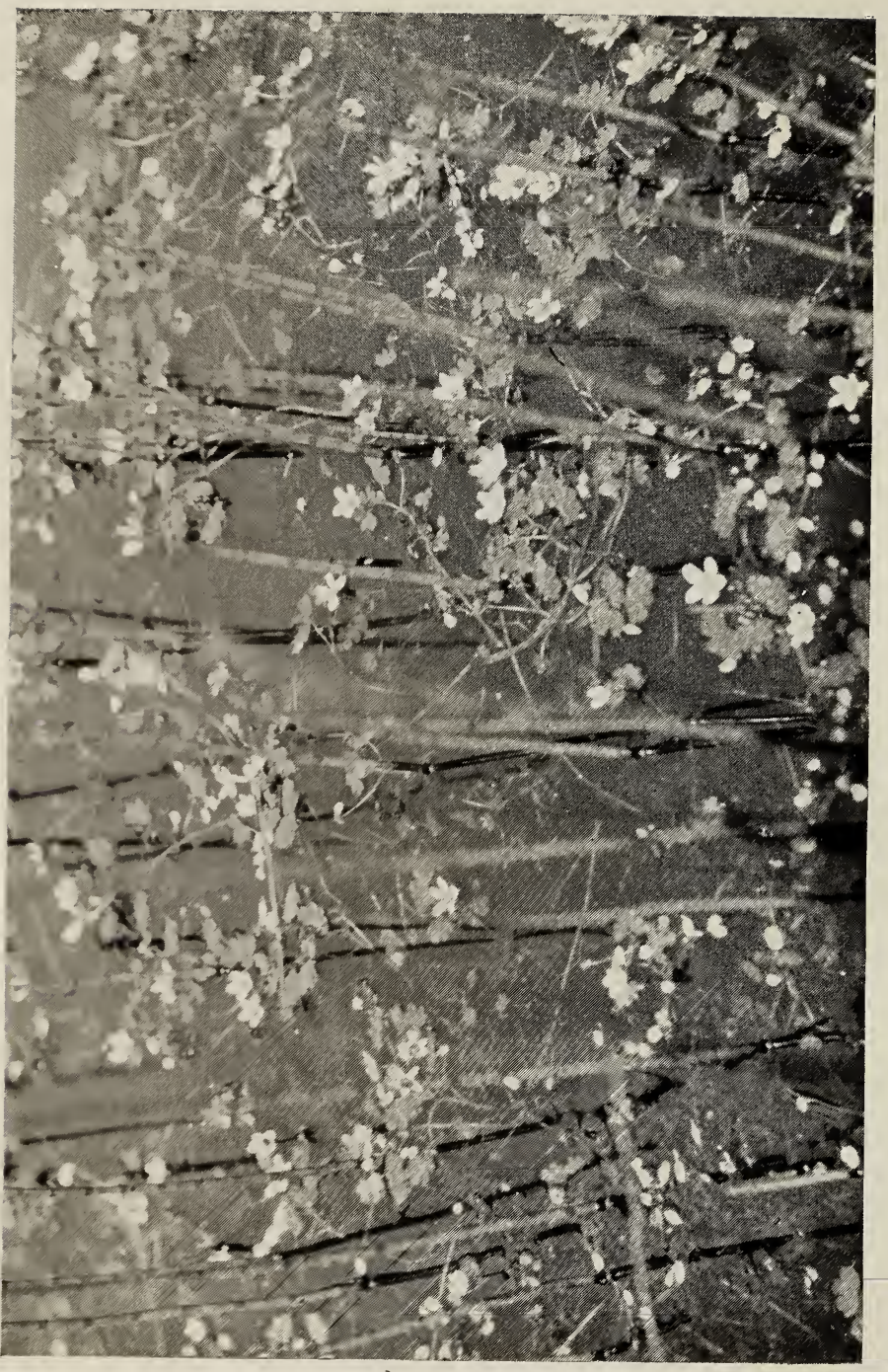

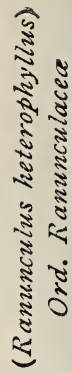

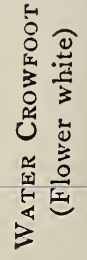




\section{WILD}
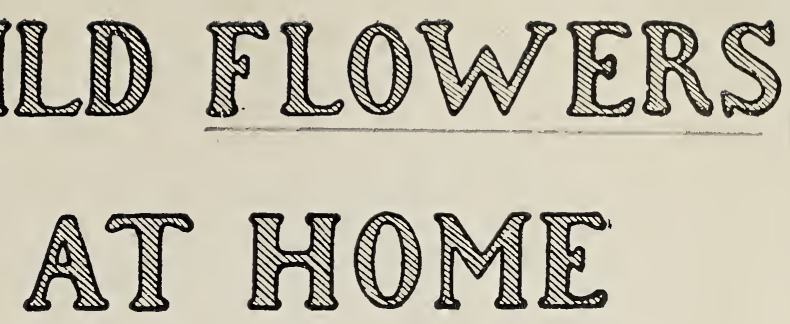

FIRST SERIES

Sixty photographs, by Cameron Todd, of British Flowering Plants grozving in their haunts

GOWANS \& GRAY, LTD.

35 Leicester Square, London, W.C. 58 Cadogan Street, Glasgow 1906 


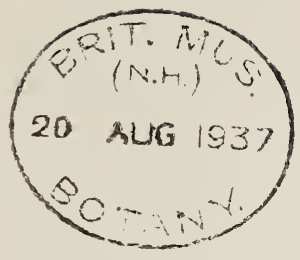

First Edition, August, 1905.

lieprnted, September, 1905.

Reprinted (with corrections), February, Igob. 
THE object of this little book, as of its predecessor, "Wild Birds at Home," is to awaken an interest in the wonders and beauties of Nature, and to stimulate a desire to study them. Some at least of the sixty (nostly common) flowers, of which photographs appear here, are known by name to everyone. Many people will know most of the plants by sight without knowing their names; only those who have studiea botany will be able to identify all. No scientific description is attempted, but the photographs and colours of the flowers appended will enable the reader, with the further aid of the fere notes at the end of the book, to identify the plants depicted with reasonable certainty. These sixty photographs were all taken in the month of June, but many of the flowers bloom on throughout the seasin. The nomenclature and order adopted are those of "Hooker's Student's Flora," I884 Edition. 


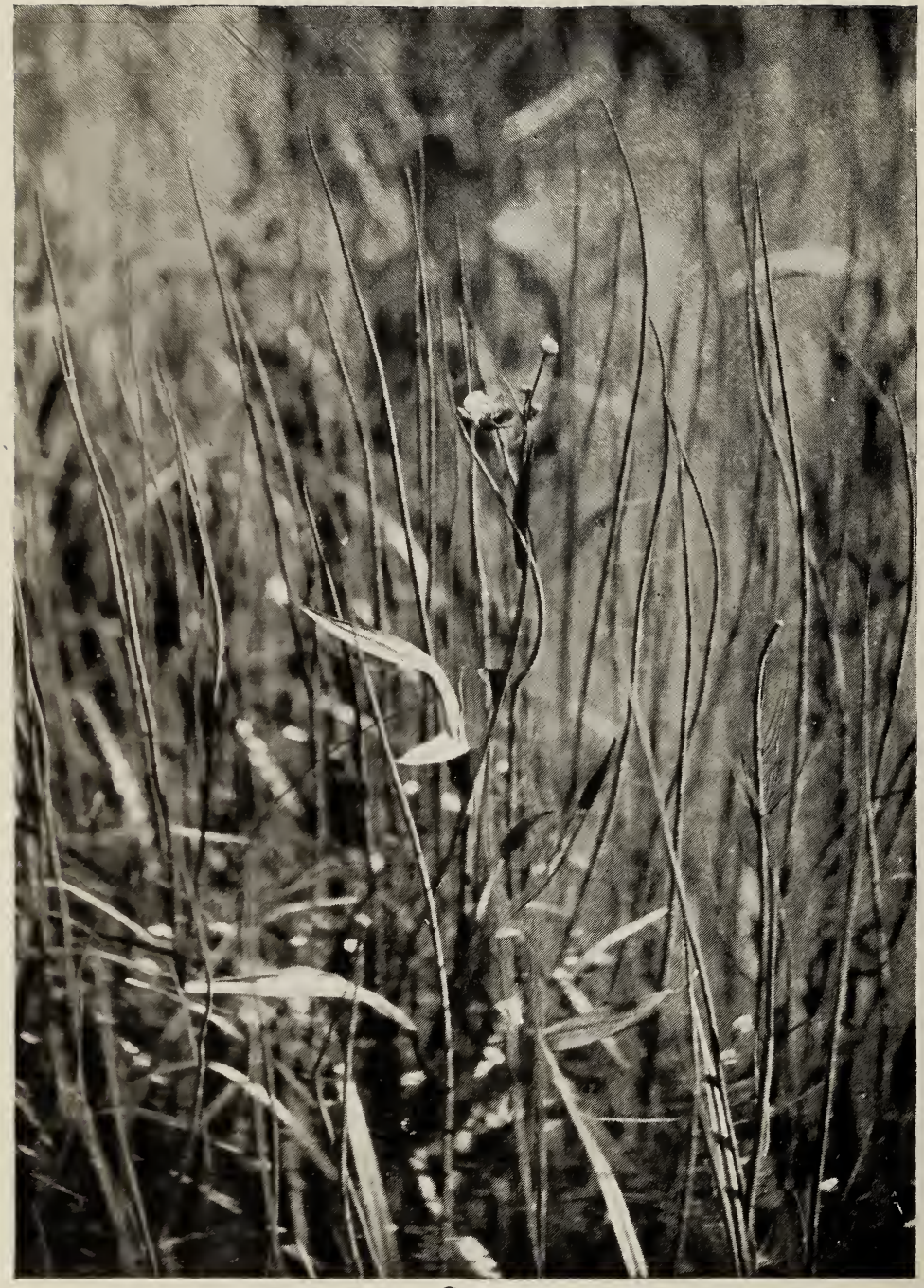

Great SPEAR-worT

(Flower yellow)
(Ranunculus lingua)

Ord. Ranunculacea 


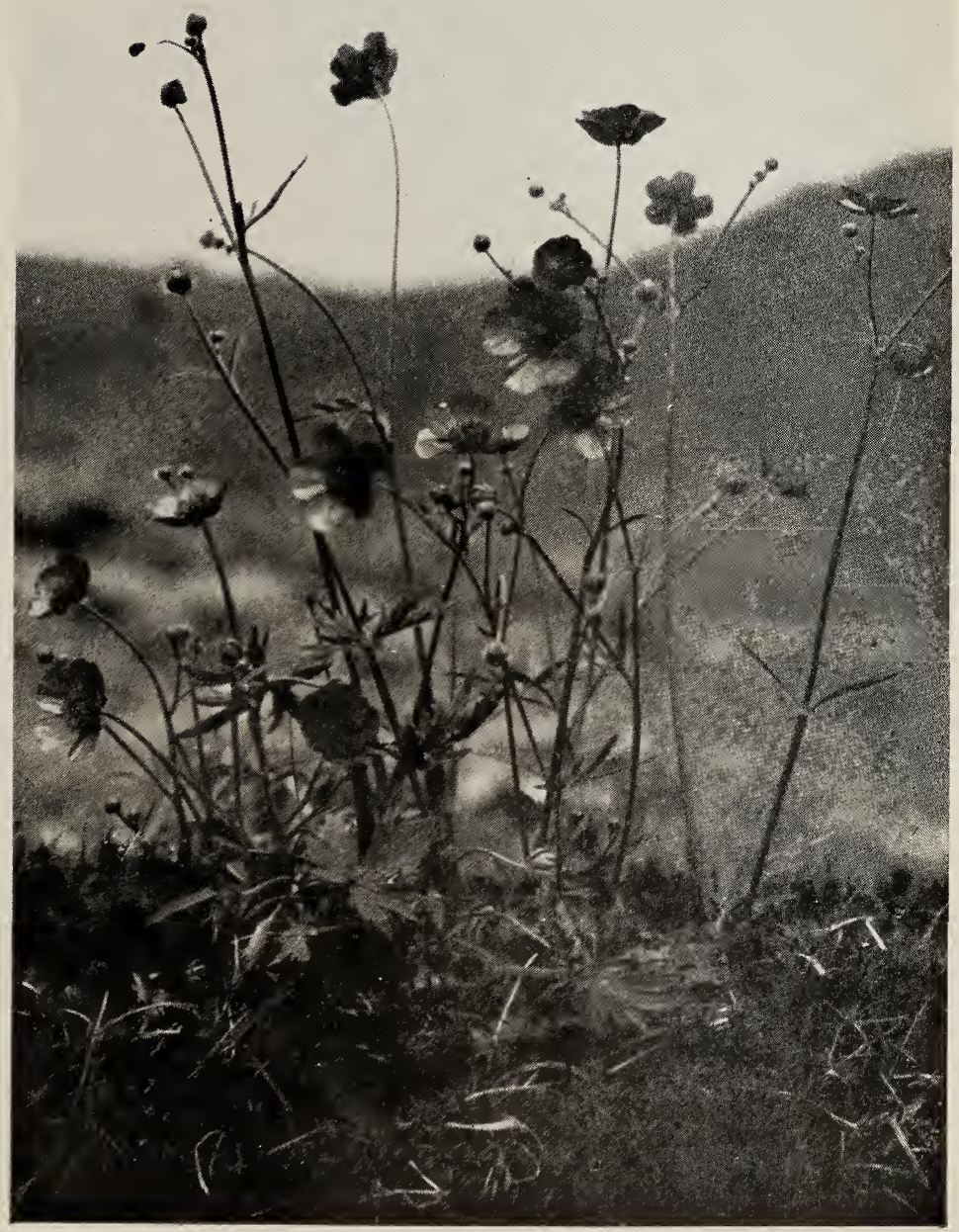

UpRIGHT Meadow Crowfoot oR ButTERCUP

(Ranunculus acris) Ord. Ranunculacece (Flower vellow) 


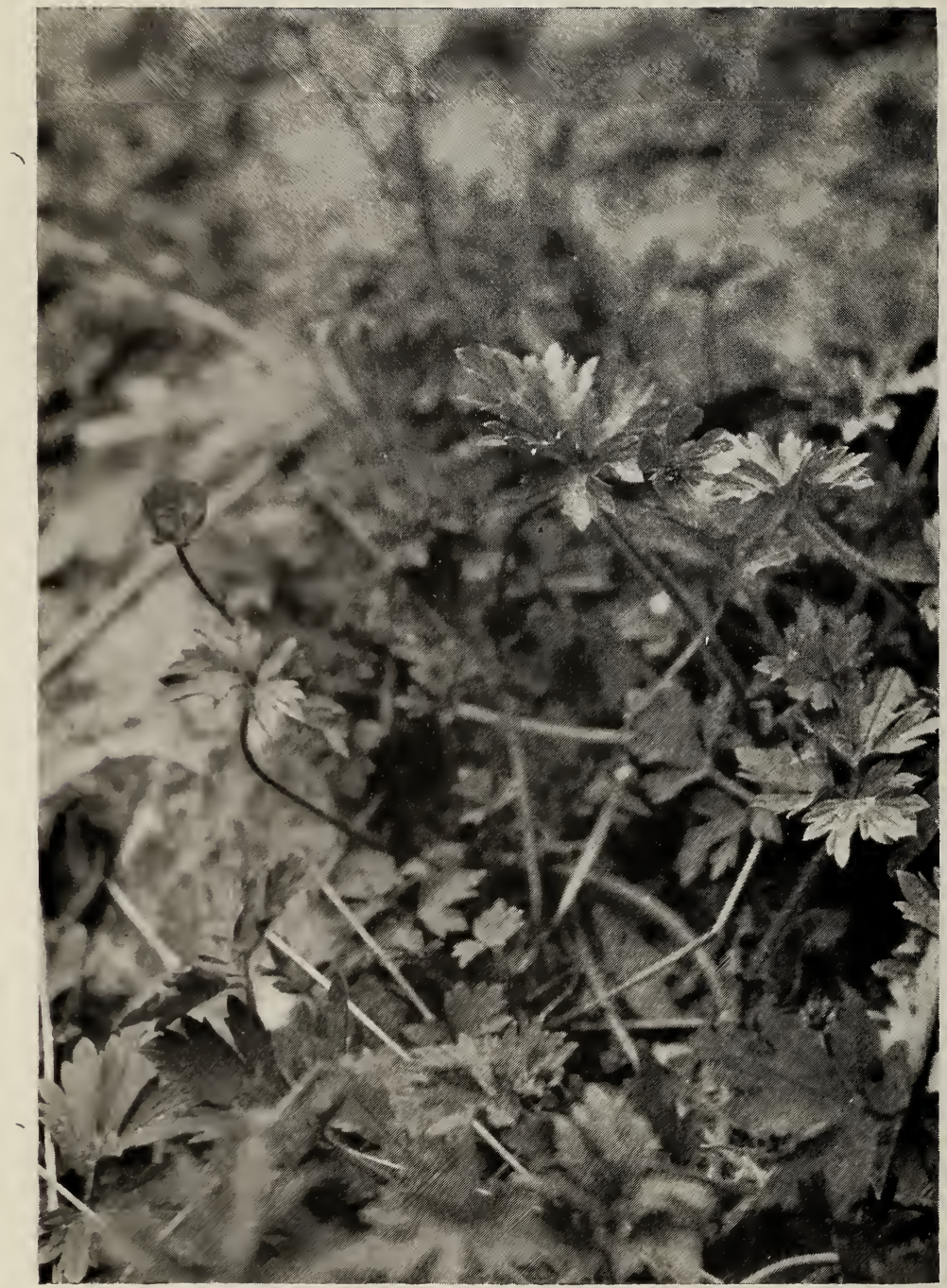

Creeping Buttercup (Flower yellow) 


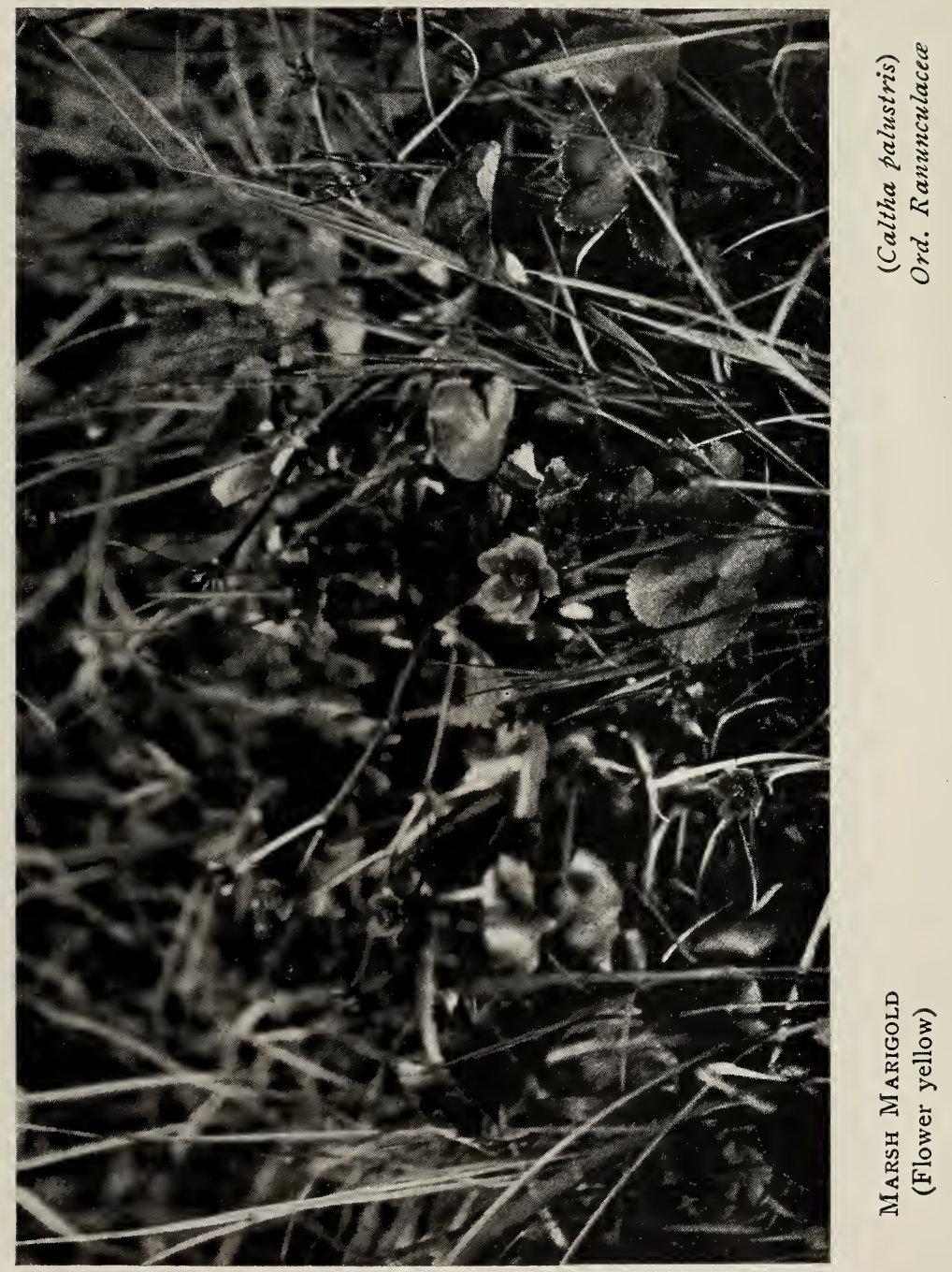




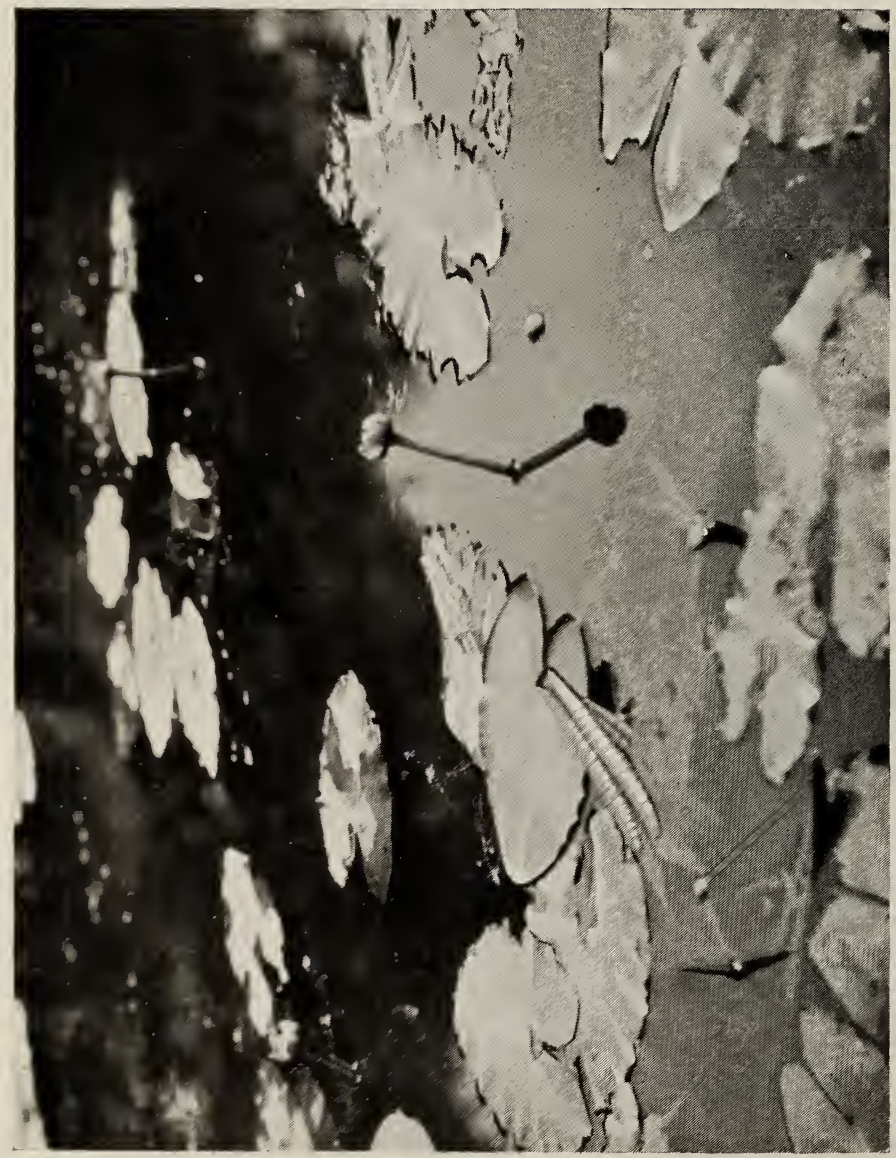

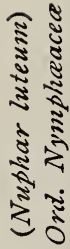

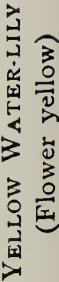




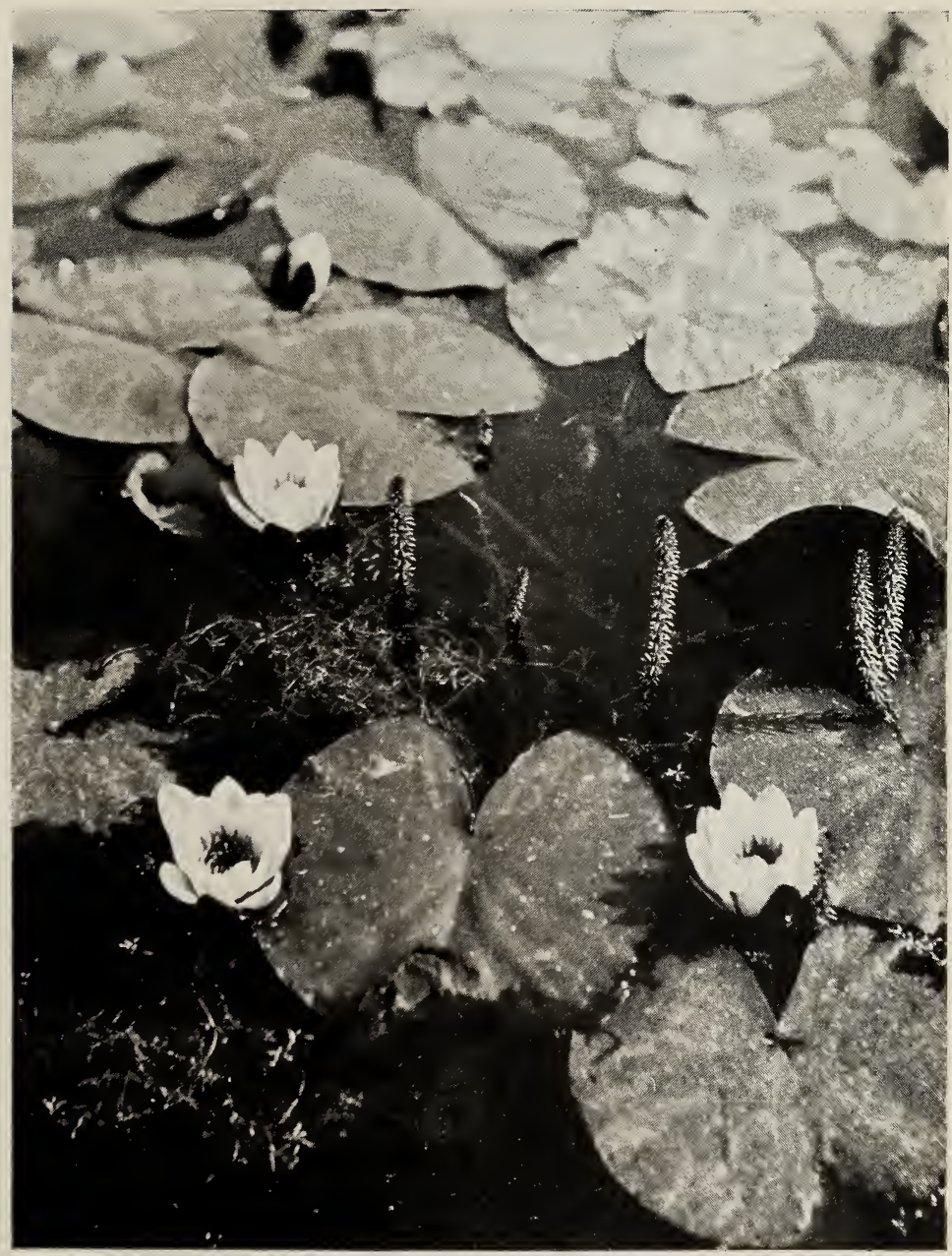

White WateR-LiLy

(Nymphaea alba)

(Flower white) Ord. Nymphaeacece 


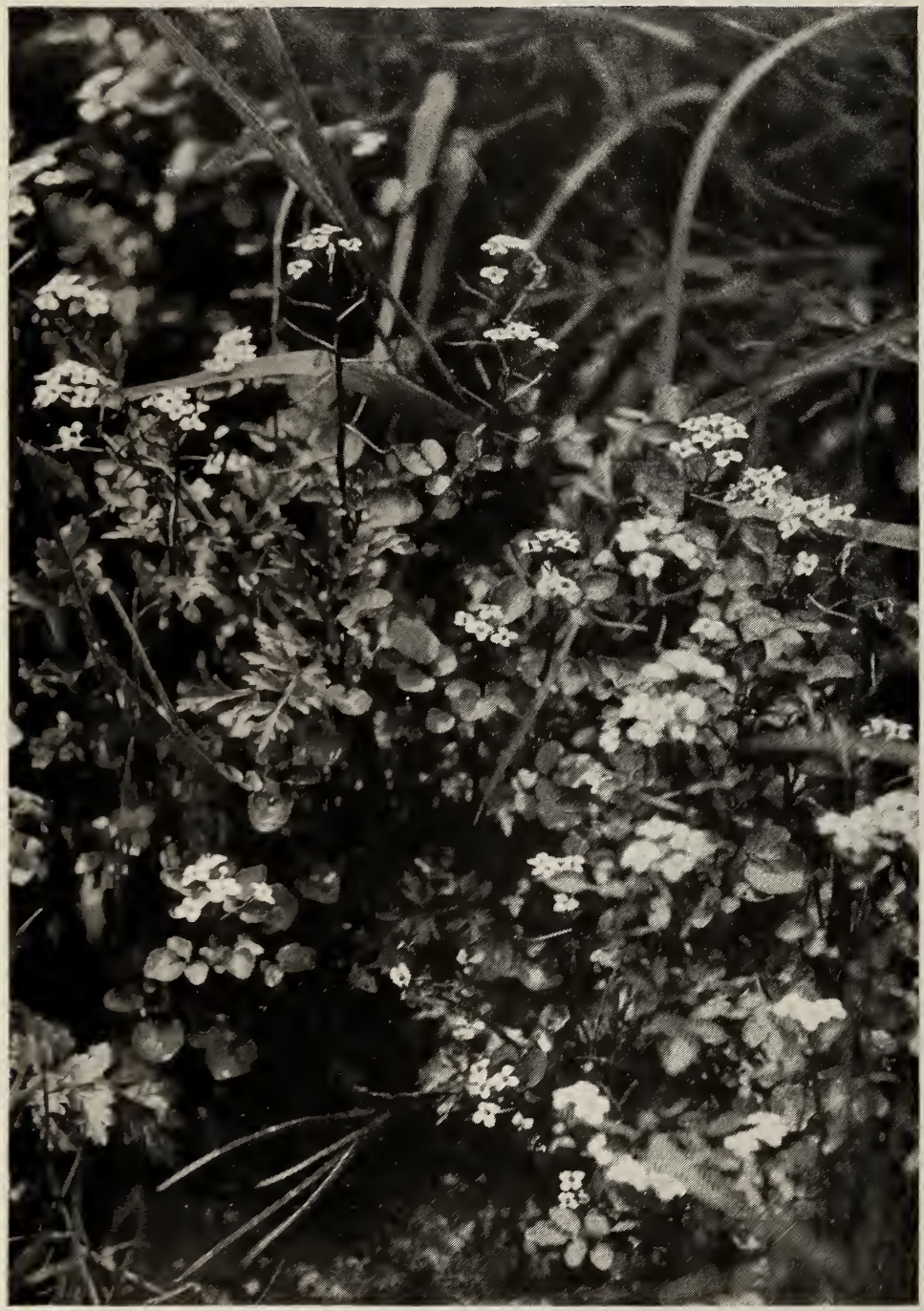

COMMON WATER-CRESS

(Nasturtium officinale)

(Flower white)

Ord. Crucifere 


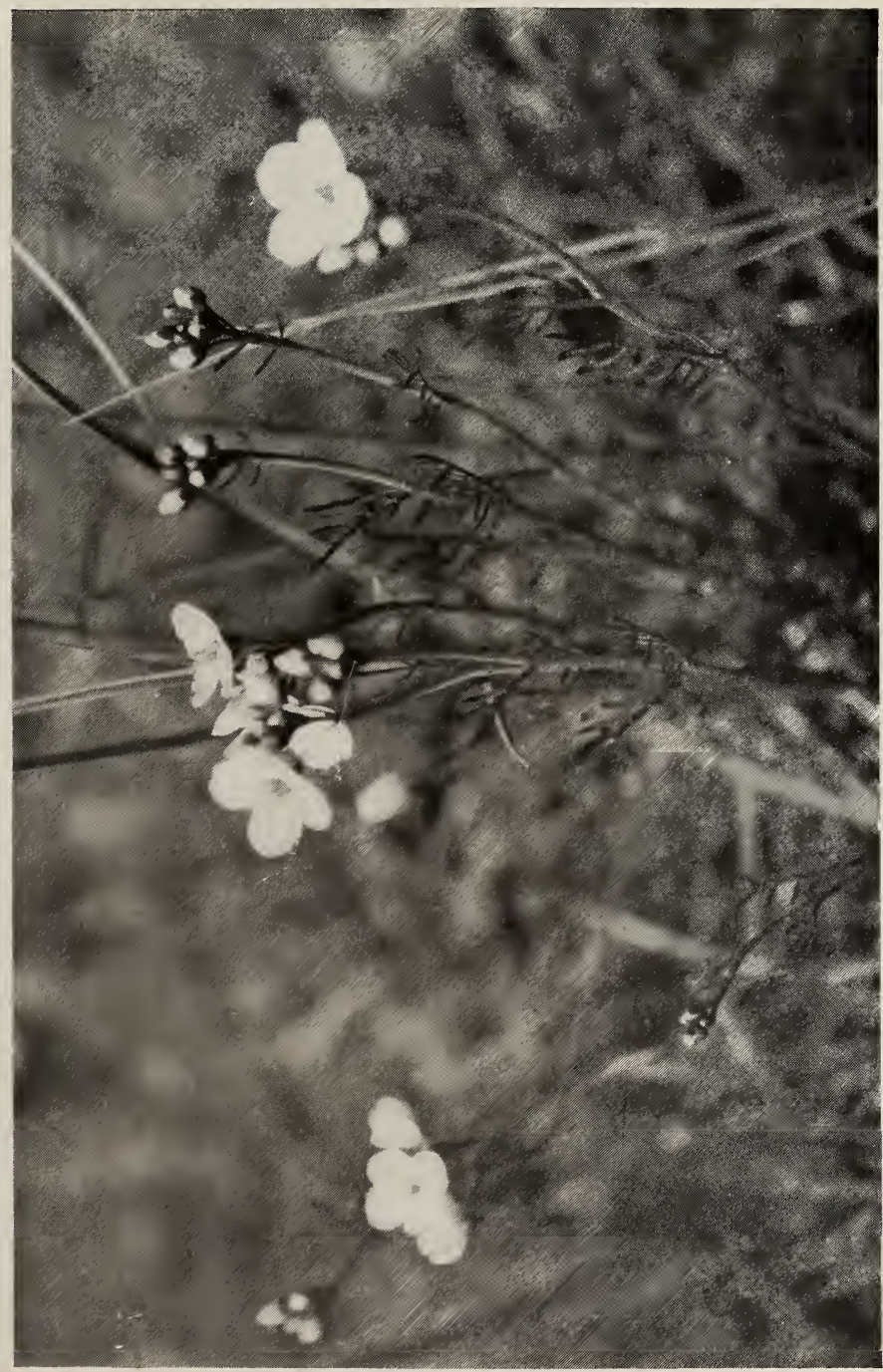

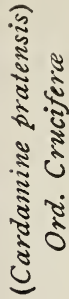

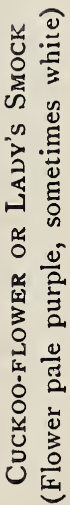




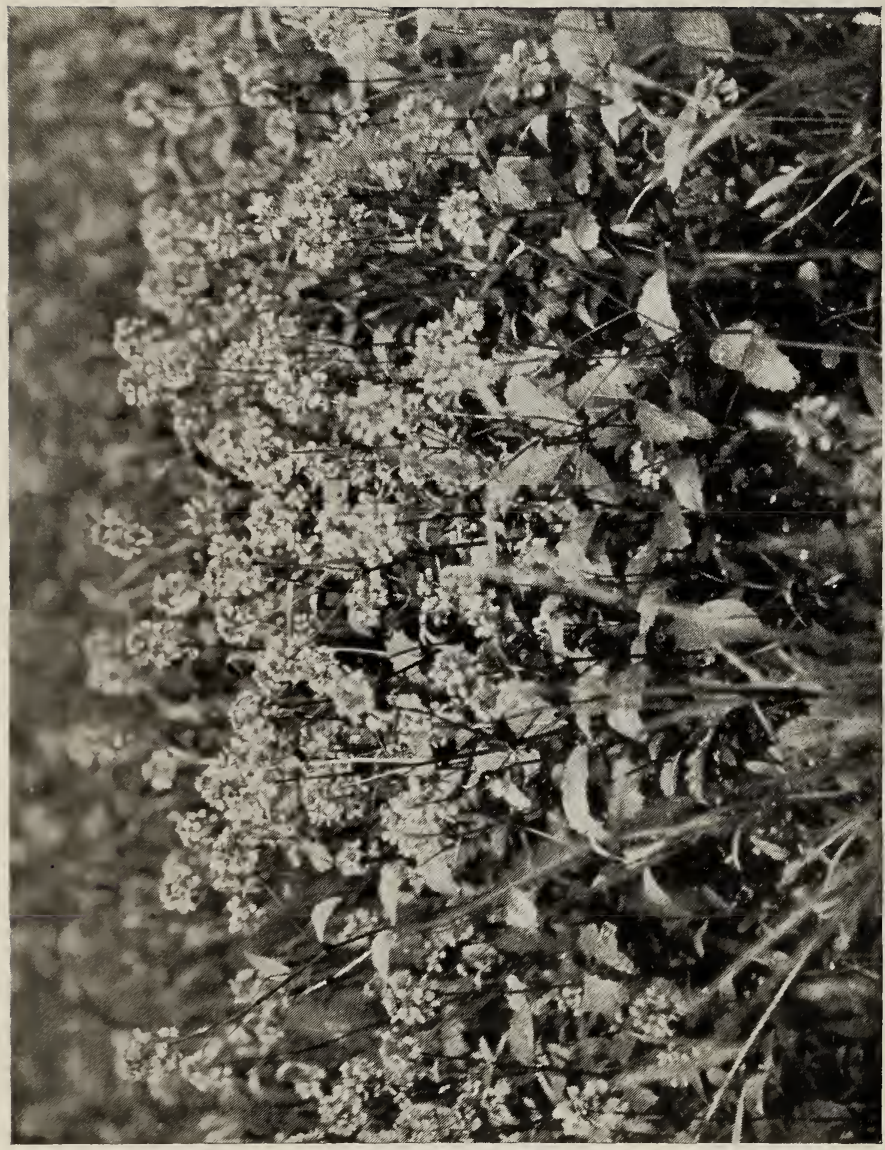

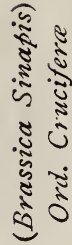

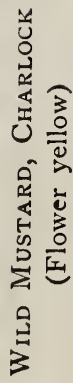




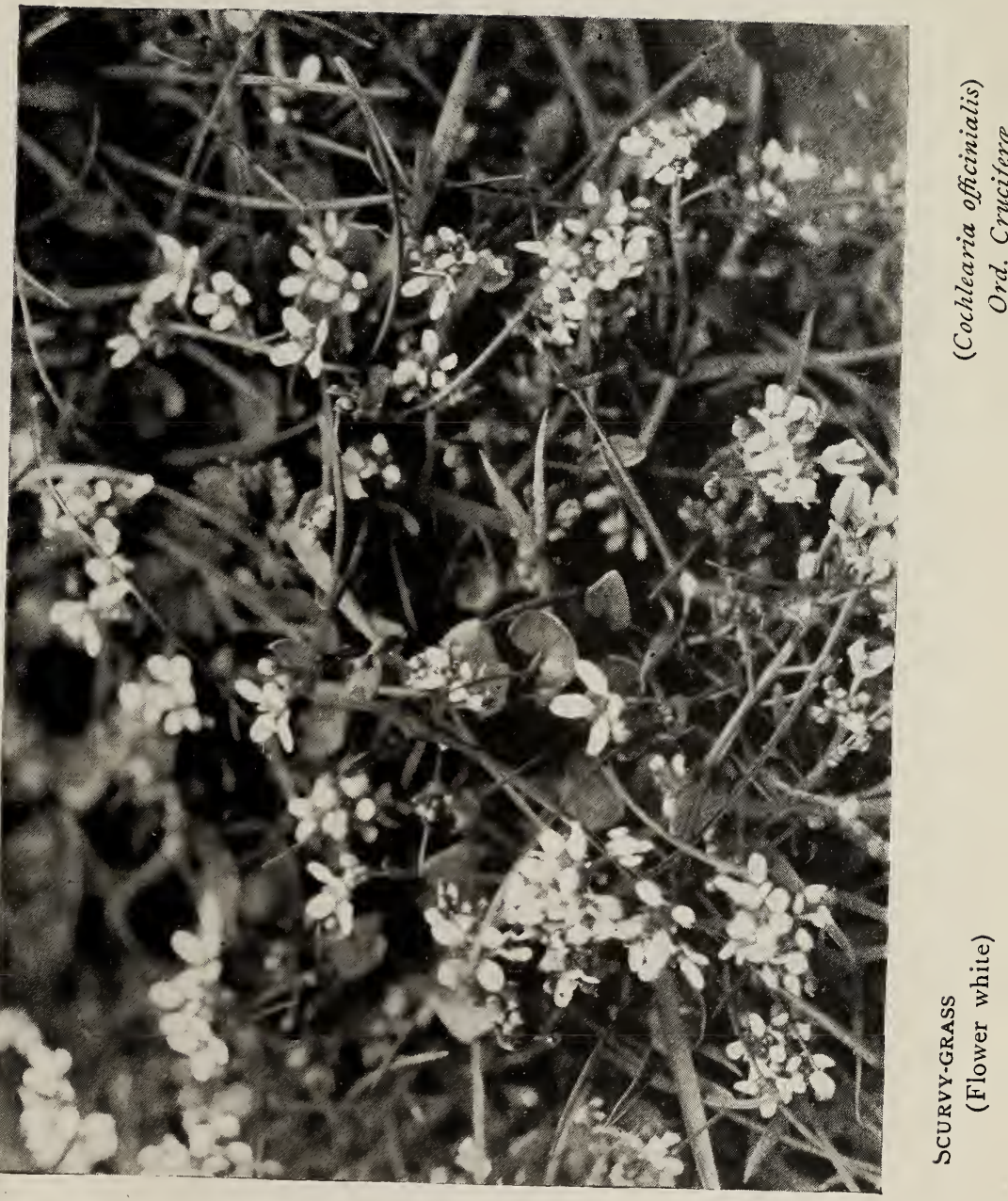




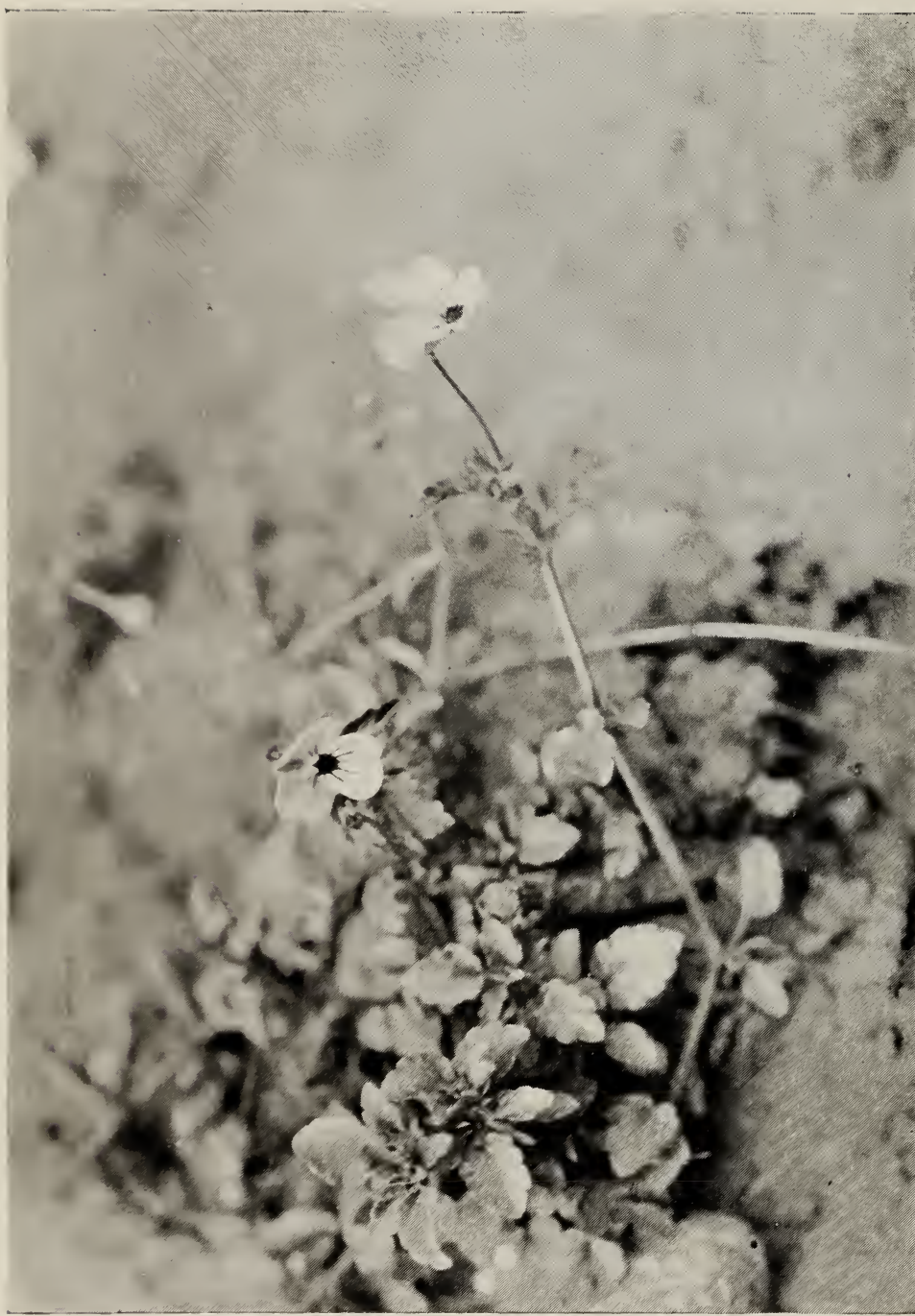

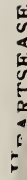




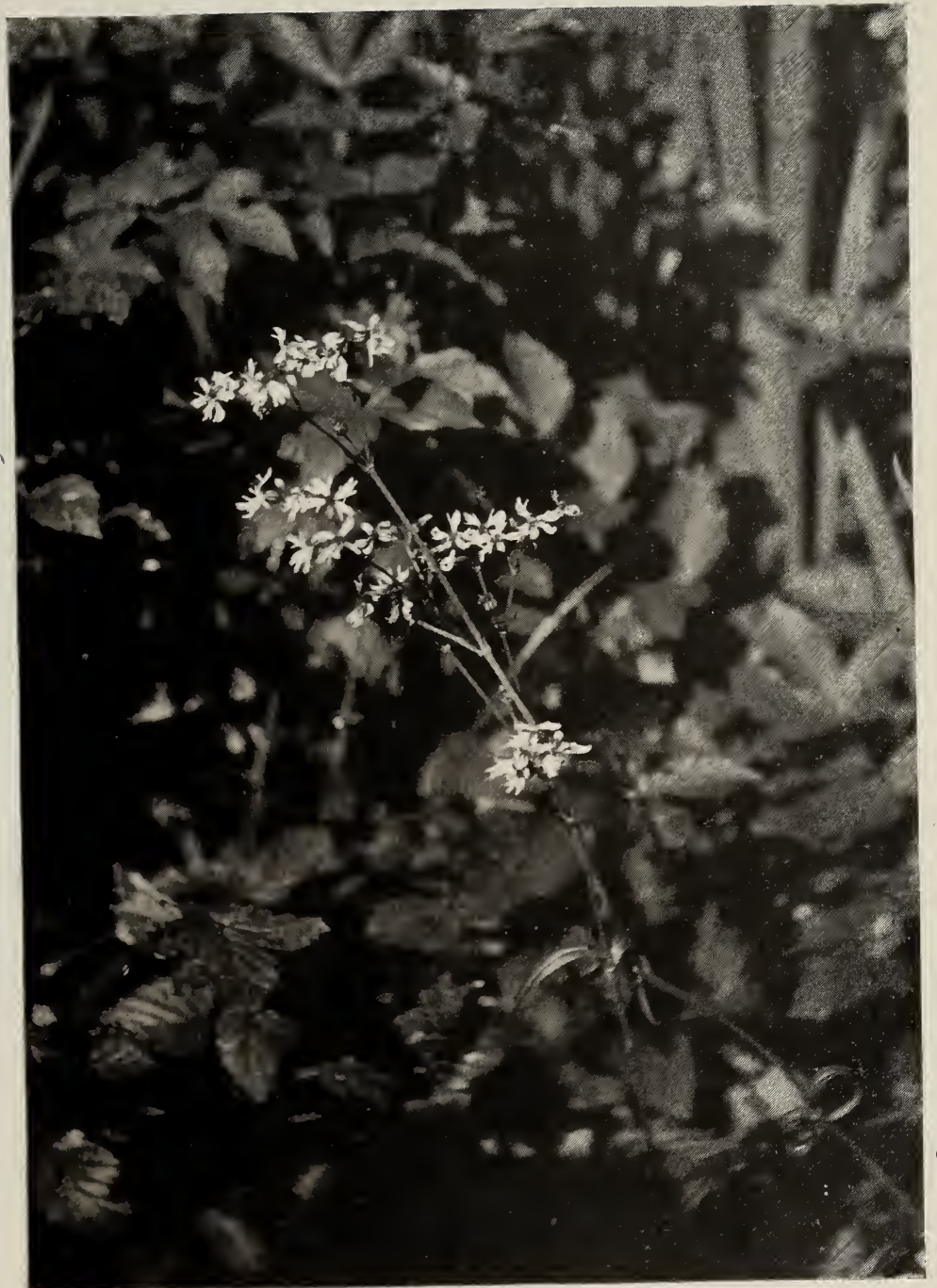

Ragged Robin or Cuckoo-flower (Flower rose-colour) 


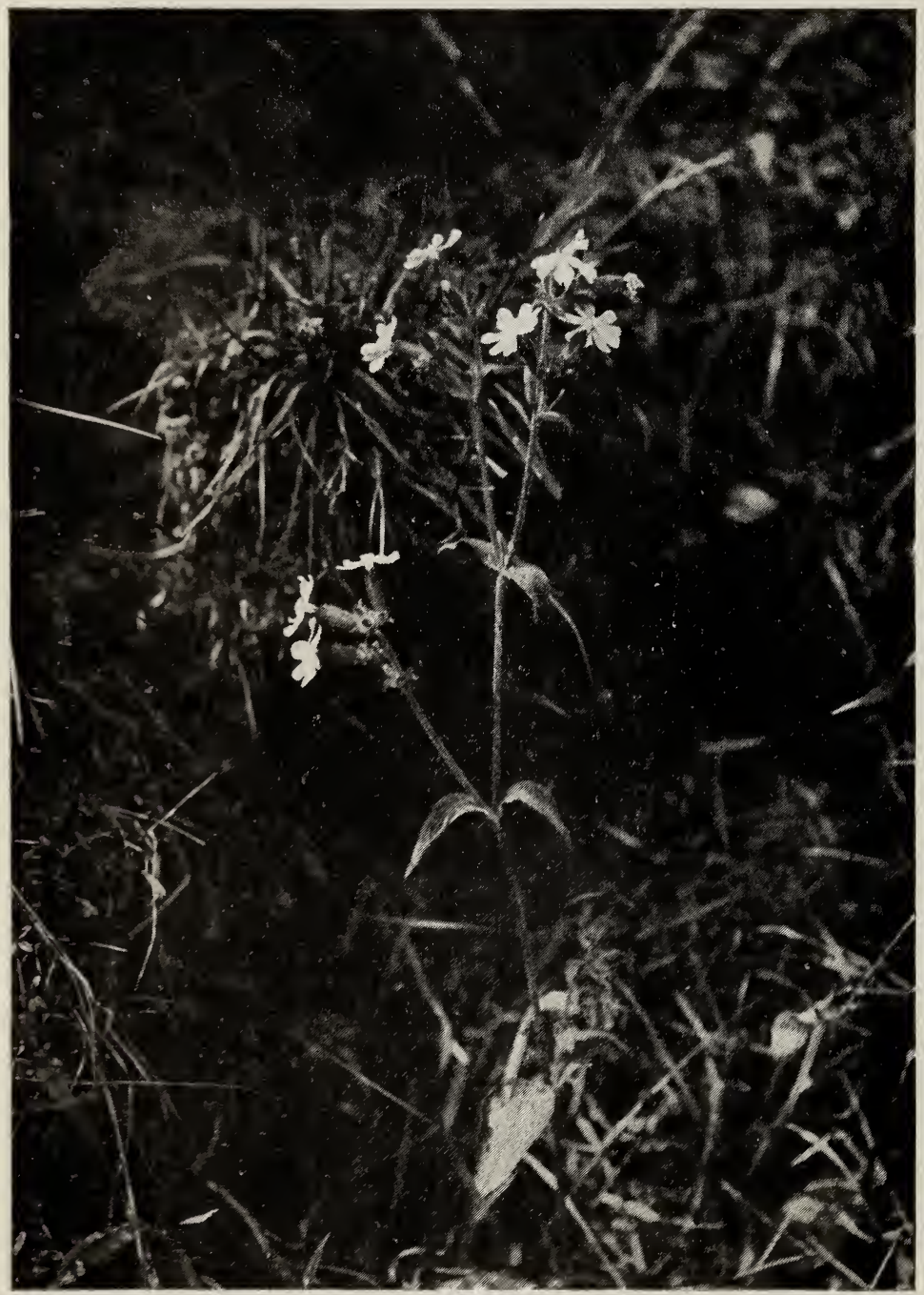

Rkid Campion

(Flower red, sometimes nearly white)
(Lychnis diurna) Ord. Caryophyllece 


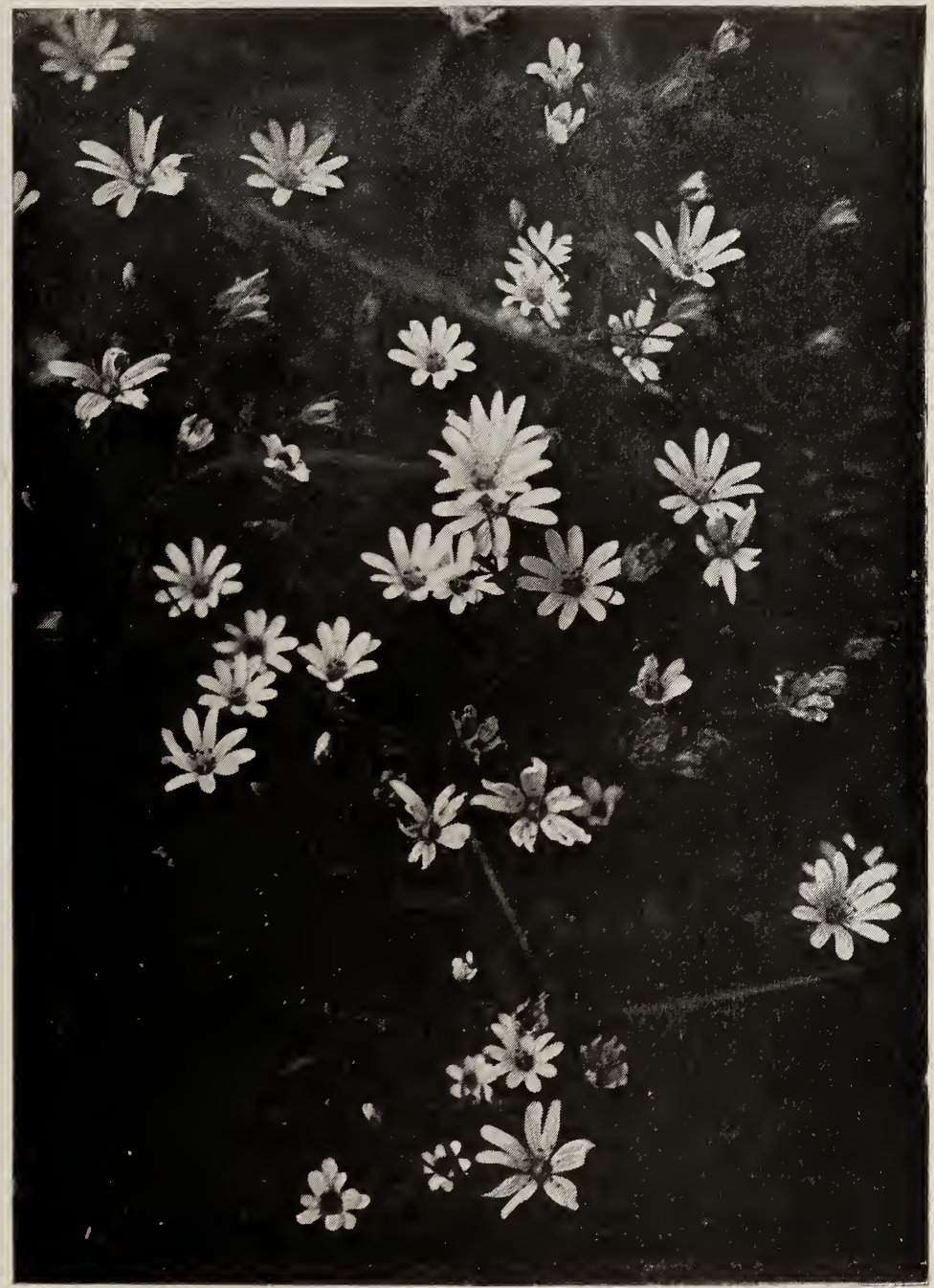




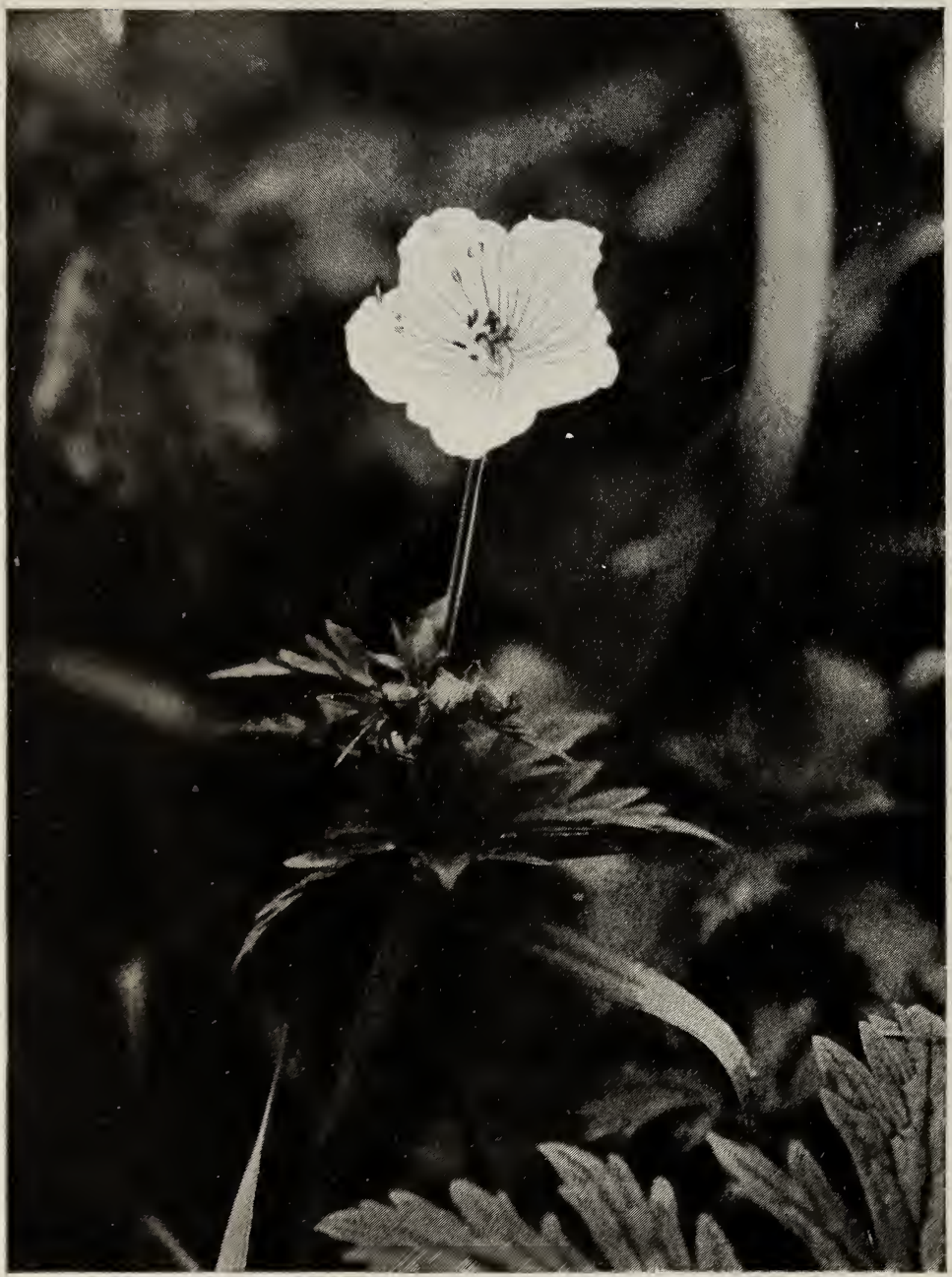

Meadow Crane's.bill

(Flower purple)
(Geranium pratense) Ord. Geraniacece 


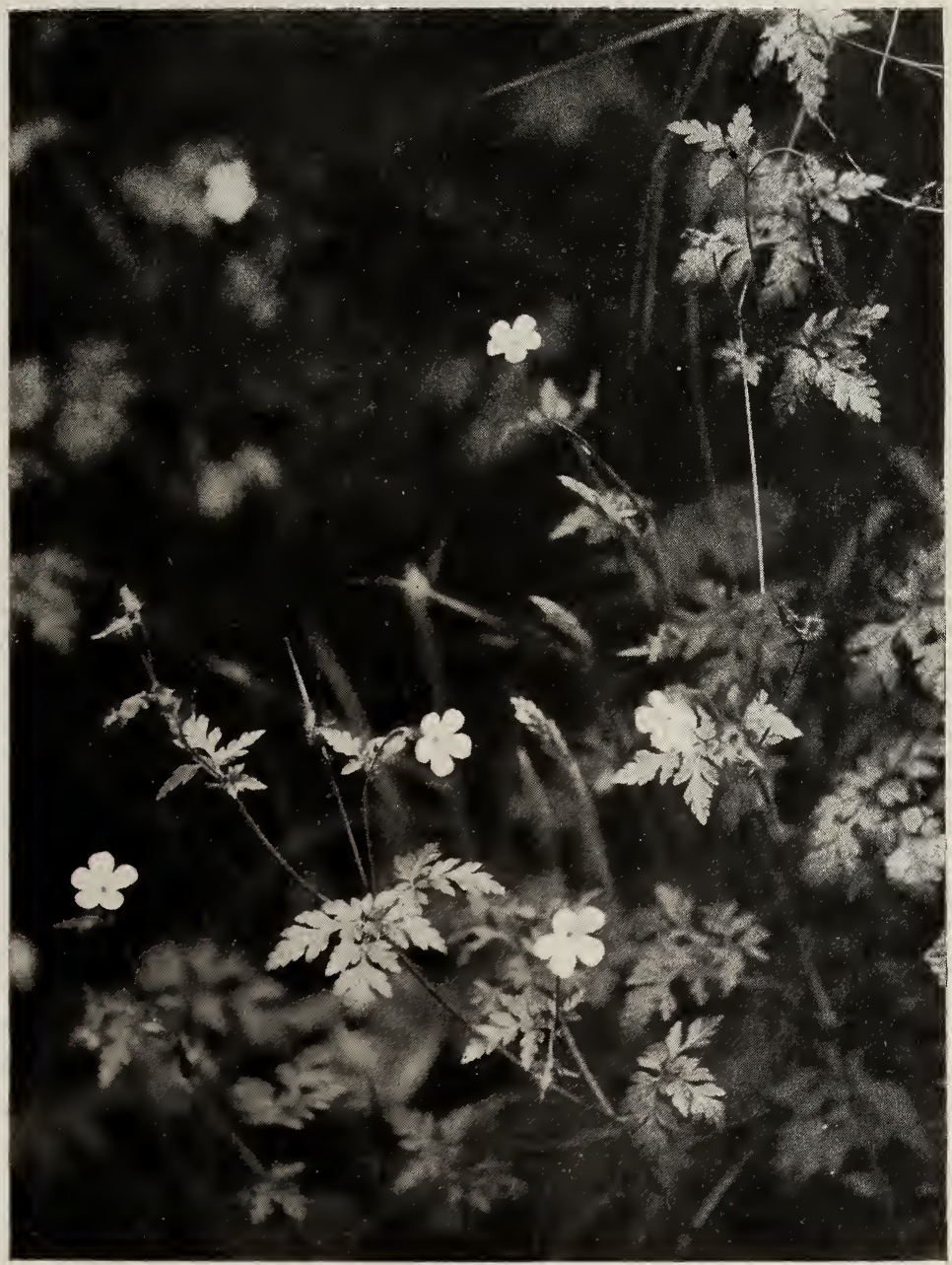

Herb Rober't or Stiniking CRANE'S-BILL
(Geranium Robertianum)

Ord. Geraniacece

(Flower rose-colour) 


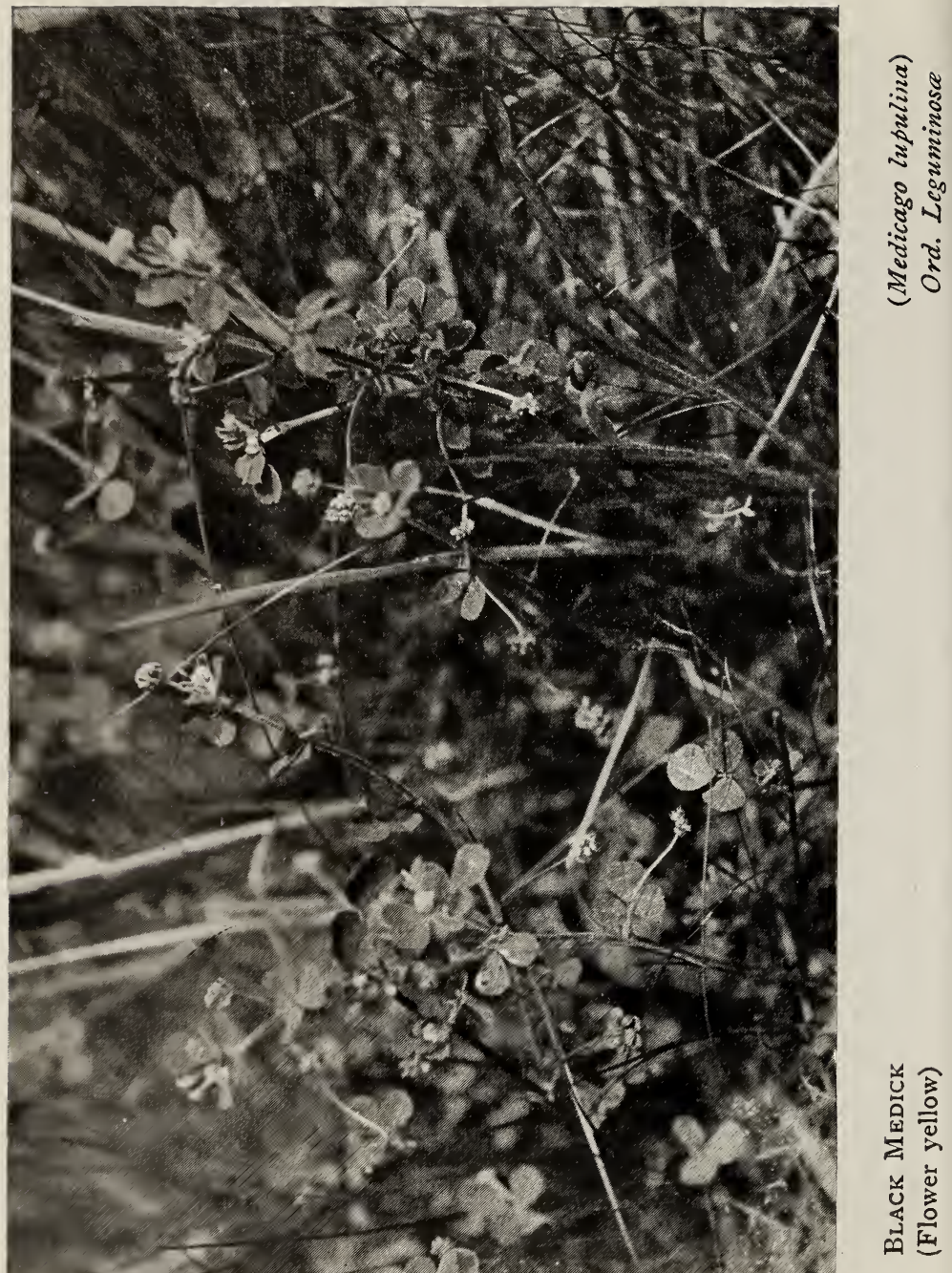




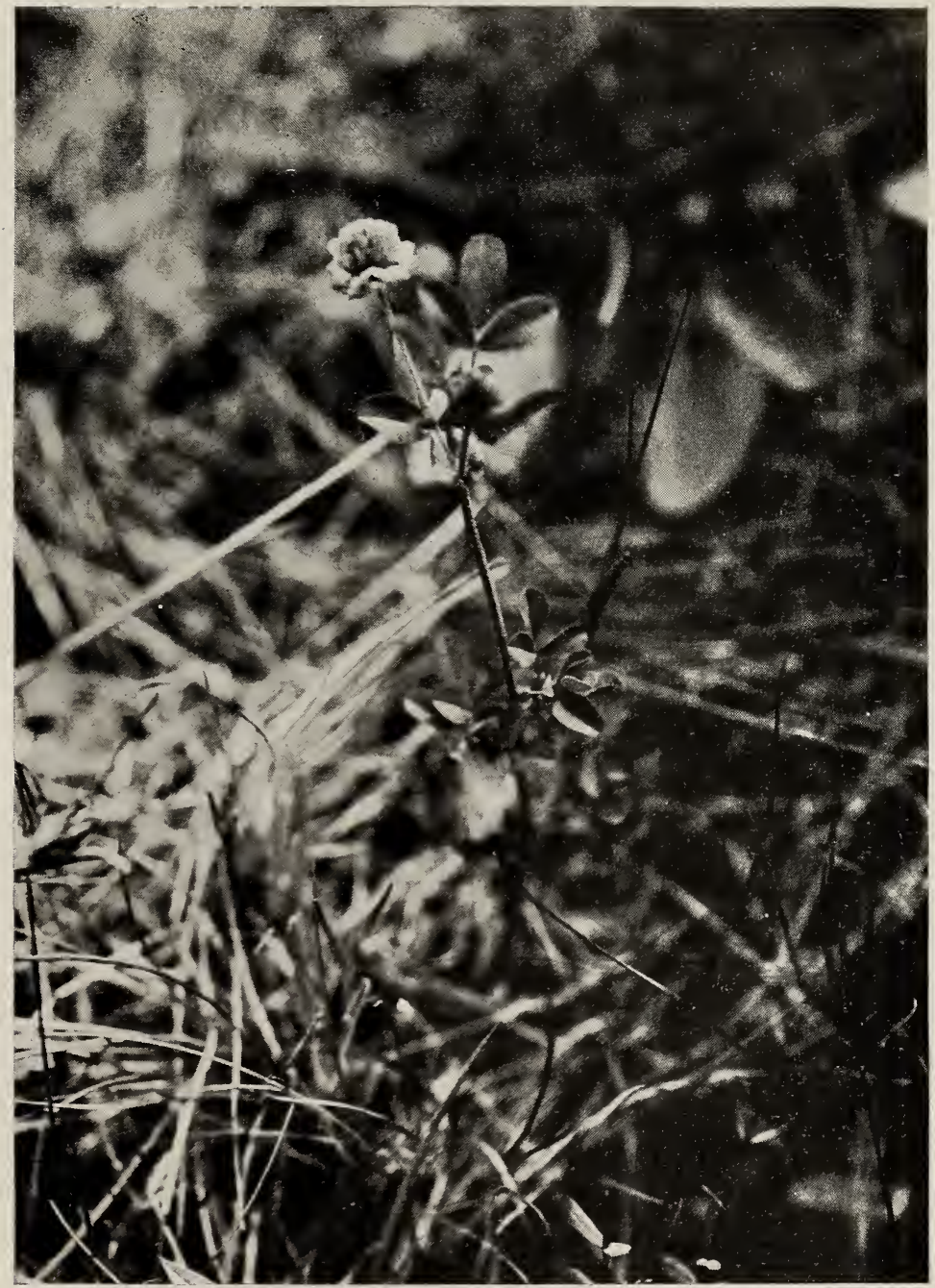

Hop TrefoIL

(Flower yellow)
(Trifolium procumbens)

Ord. Leguminosa 


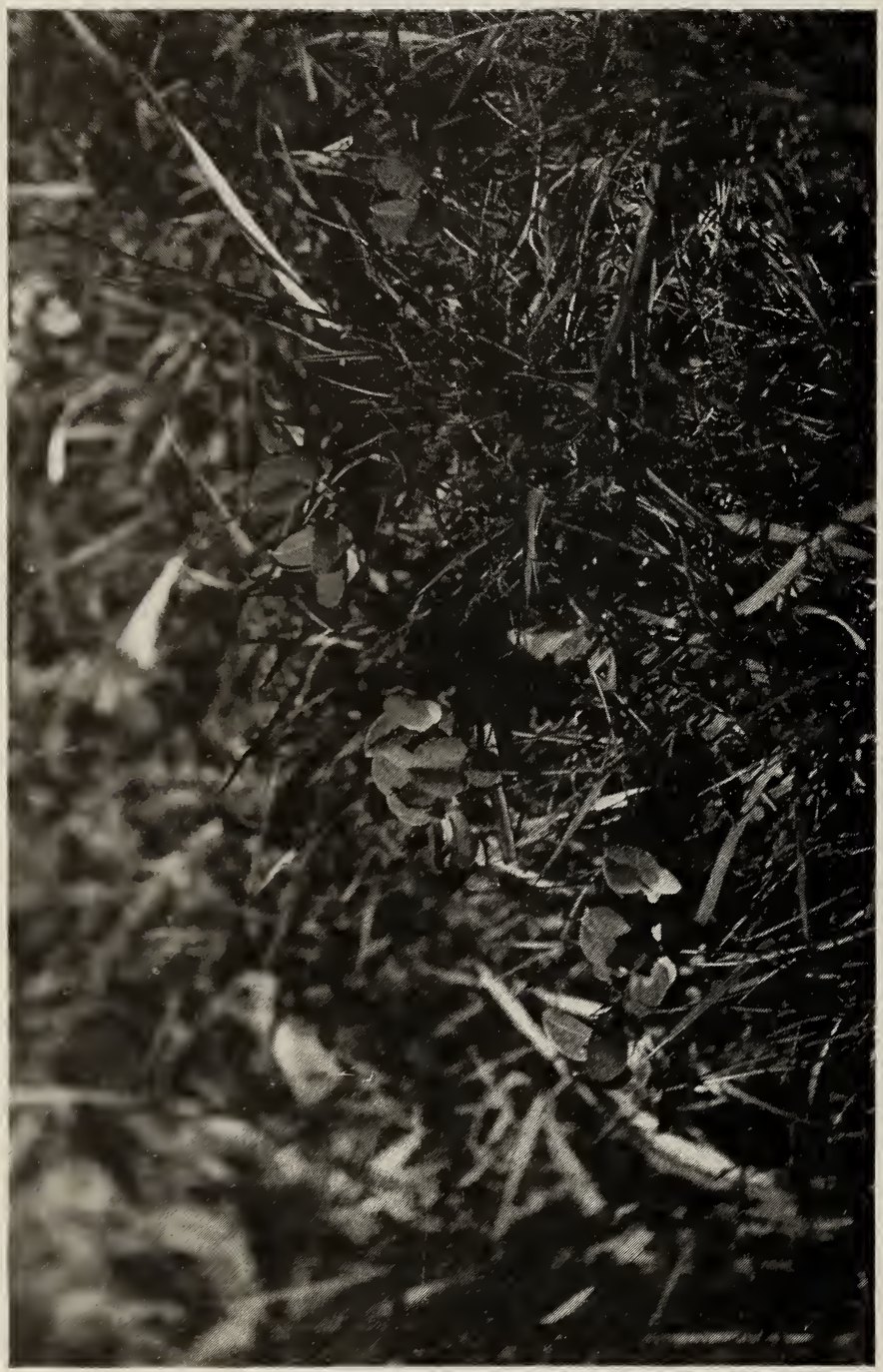

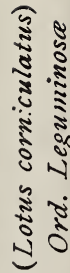

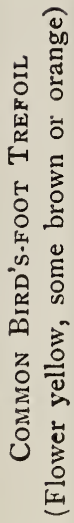




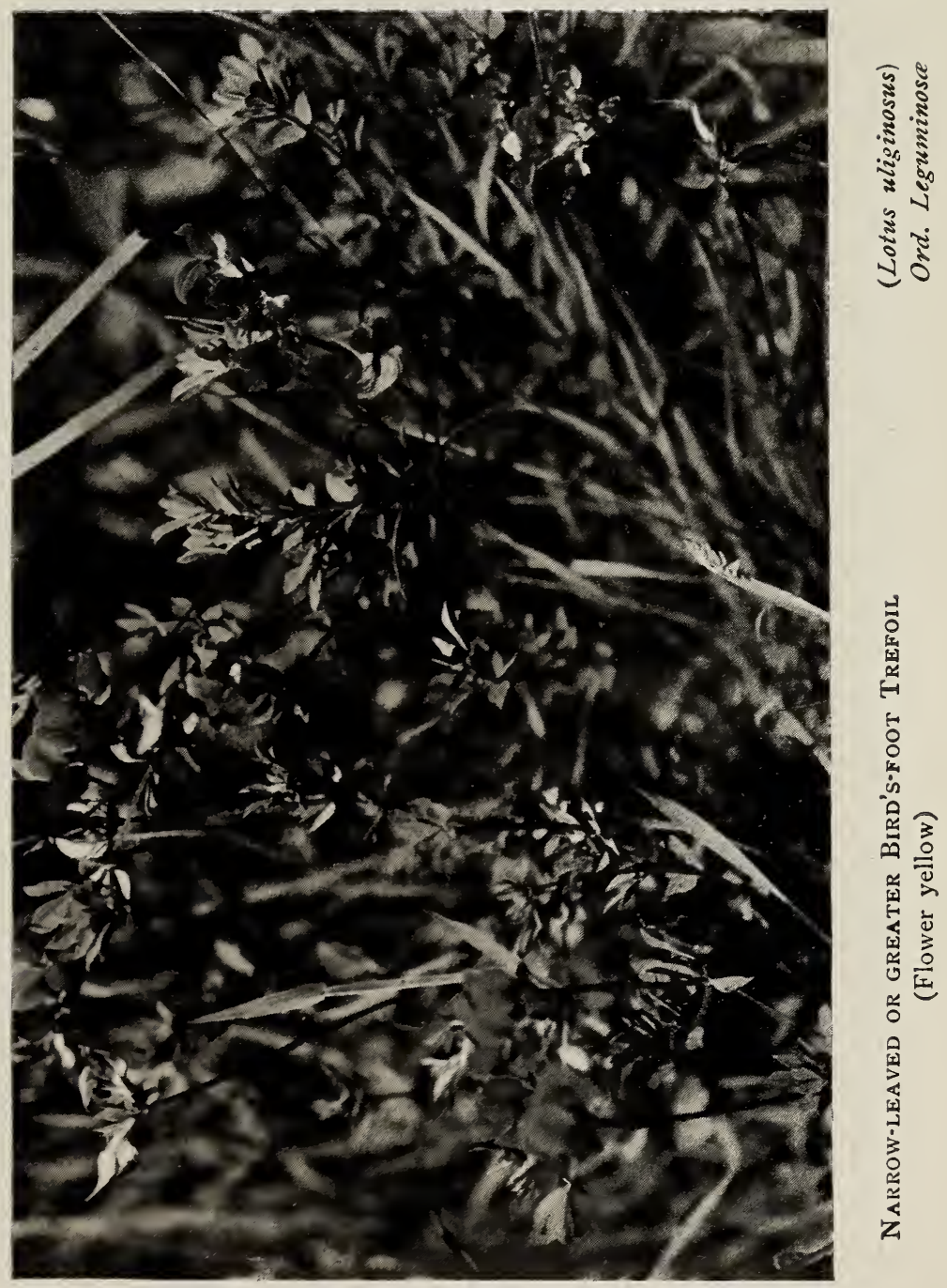




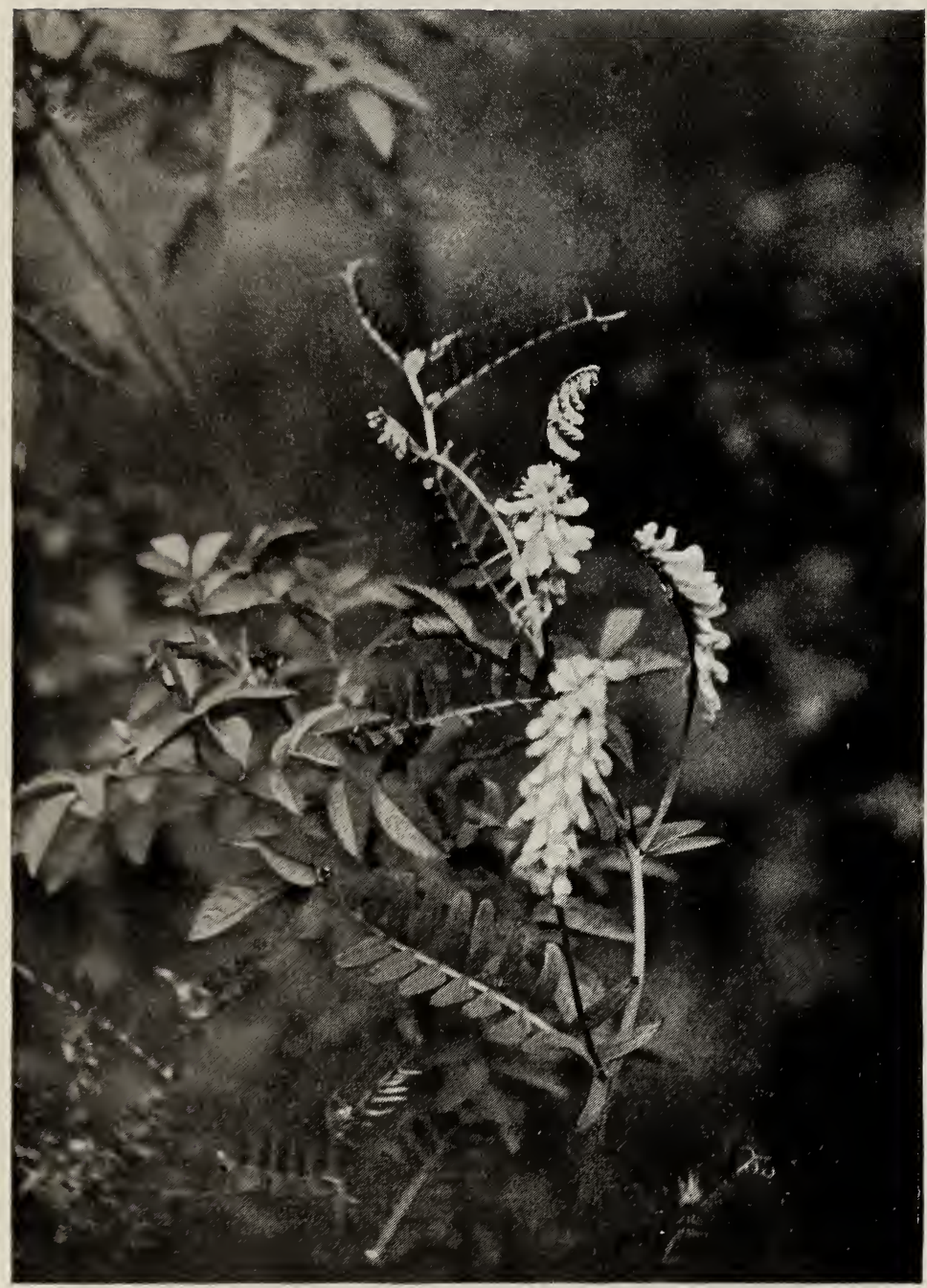

TUfted Vetch

(Flower bluish purple)
(Vicia Cracca)

ard. Leguminosa 


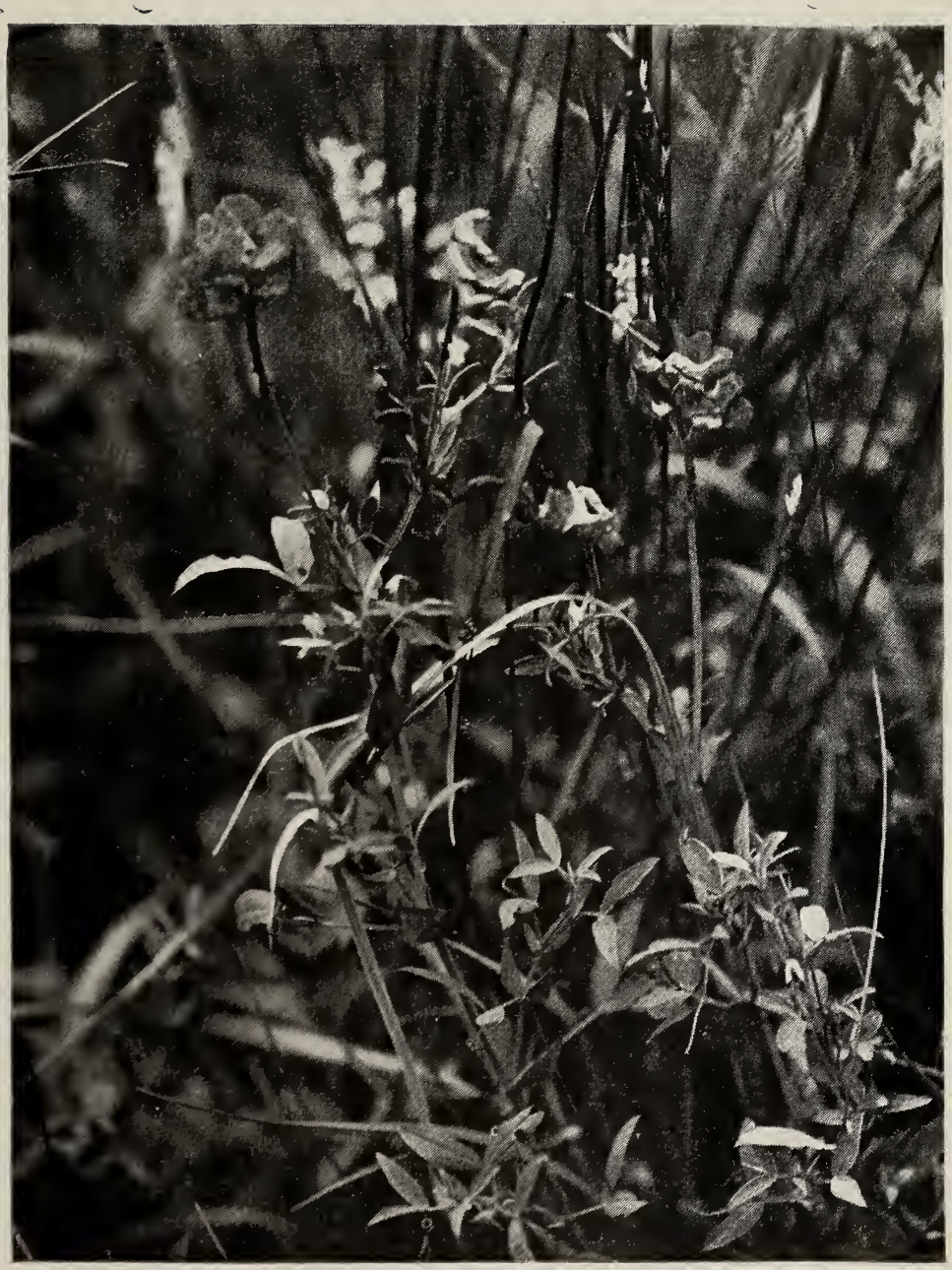

Meadow Vetchling (Flower yellow) 


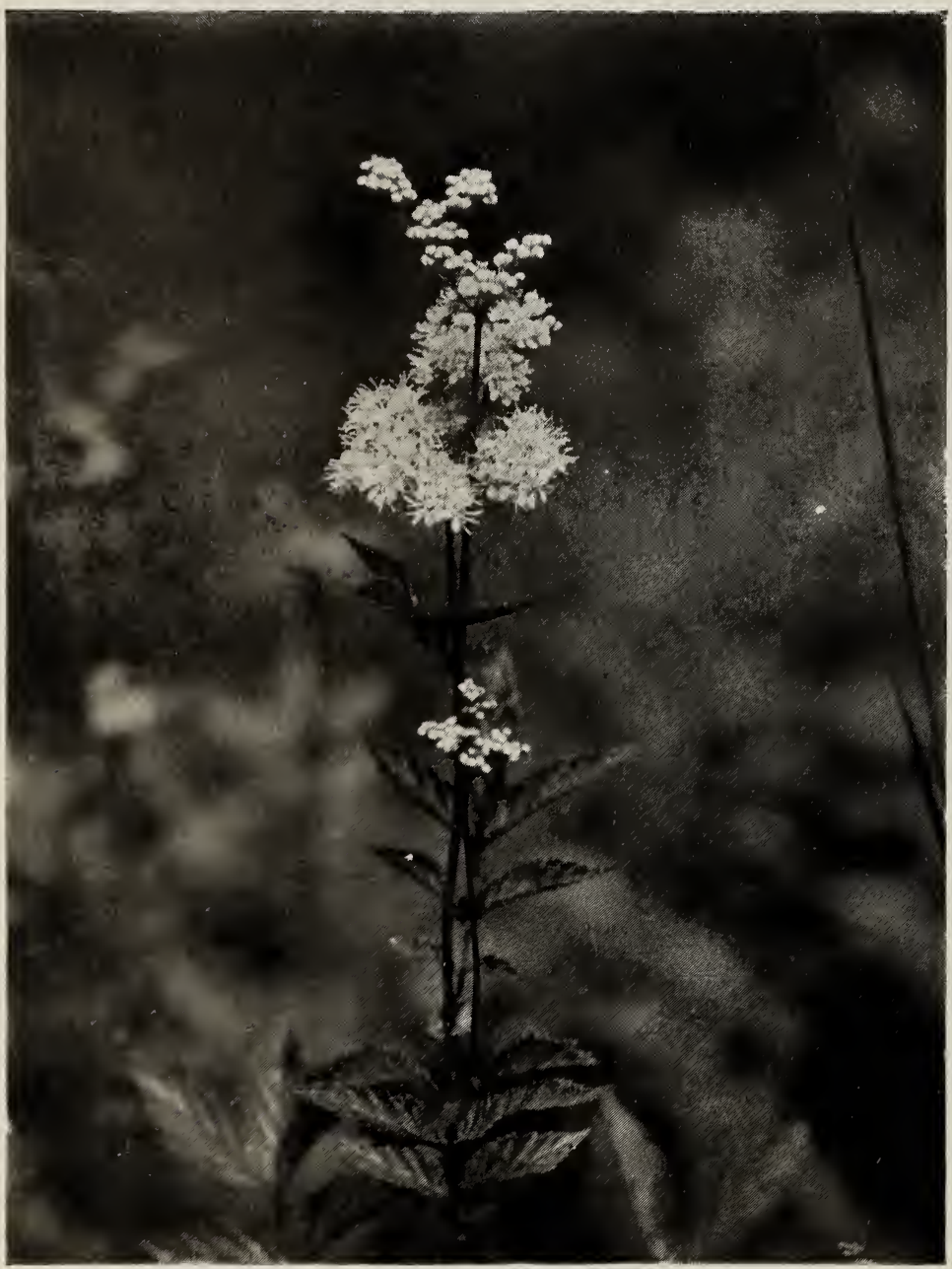

MEADOW-SWEET OR QUEEN OF THE MEADOW (Flower yellowish white)
(Spircea Ulmaria) Ord. Rosacece 


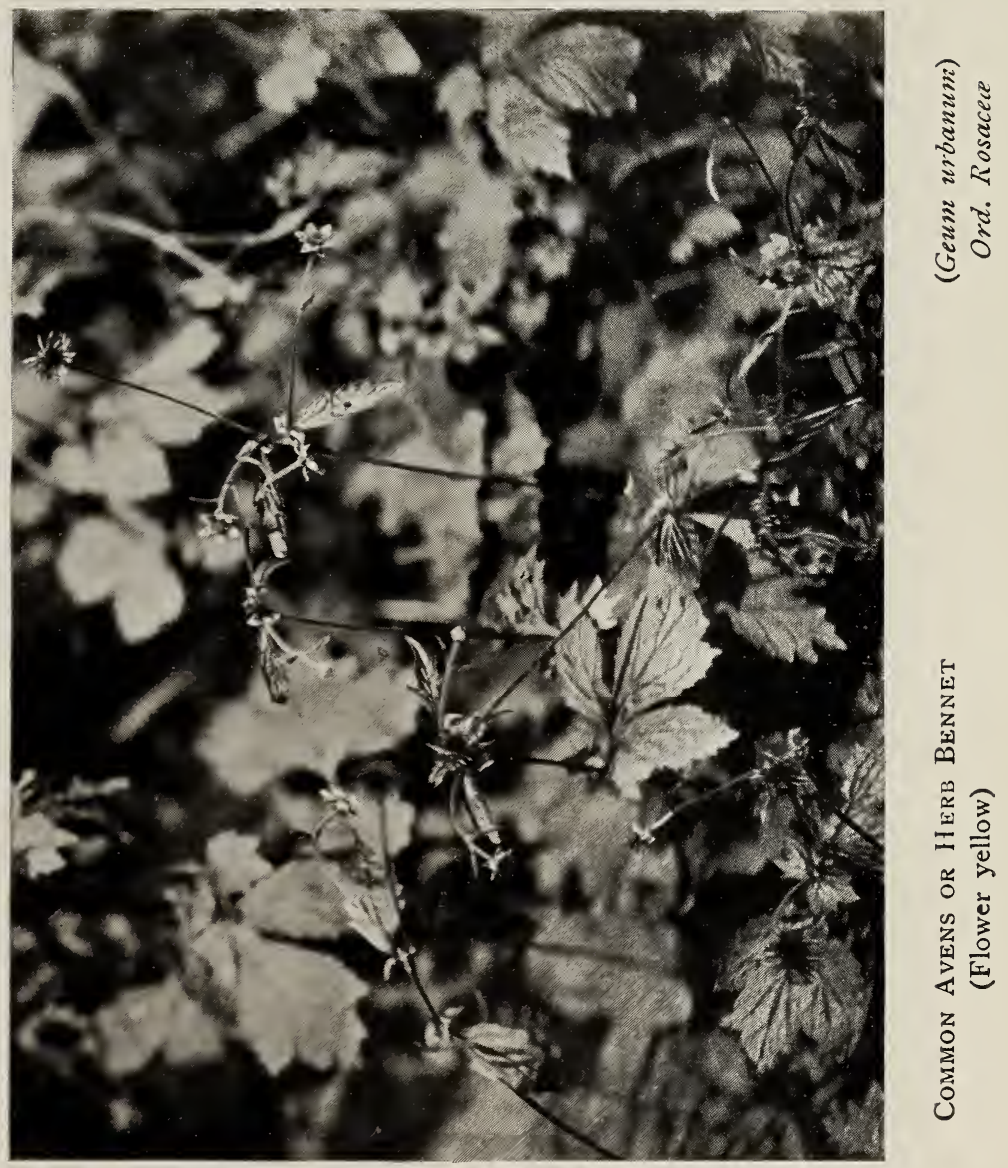




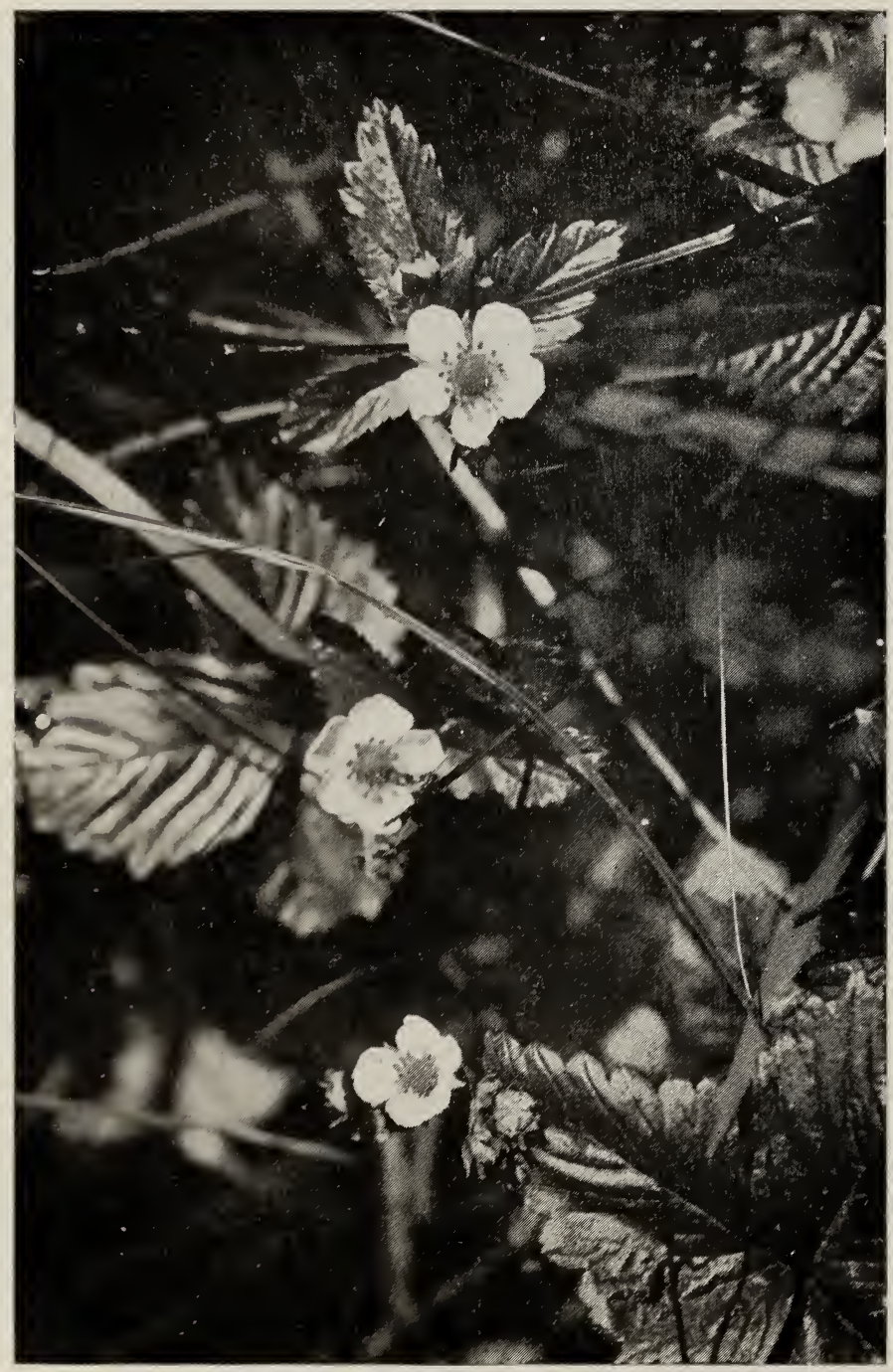

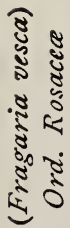

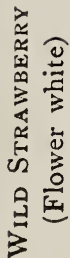




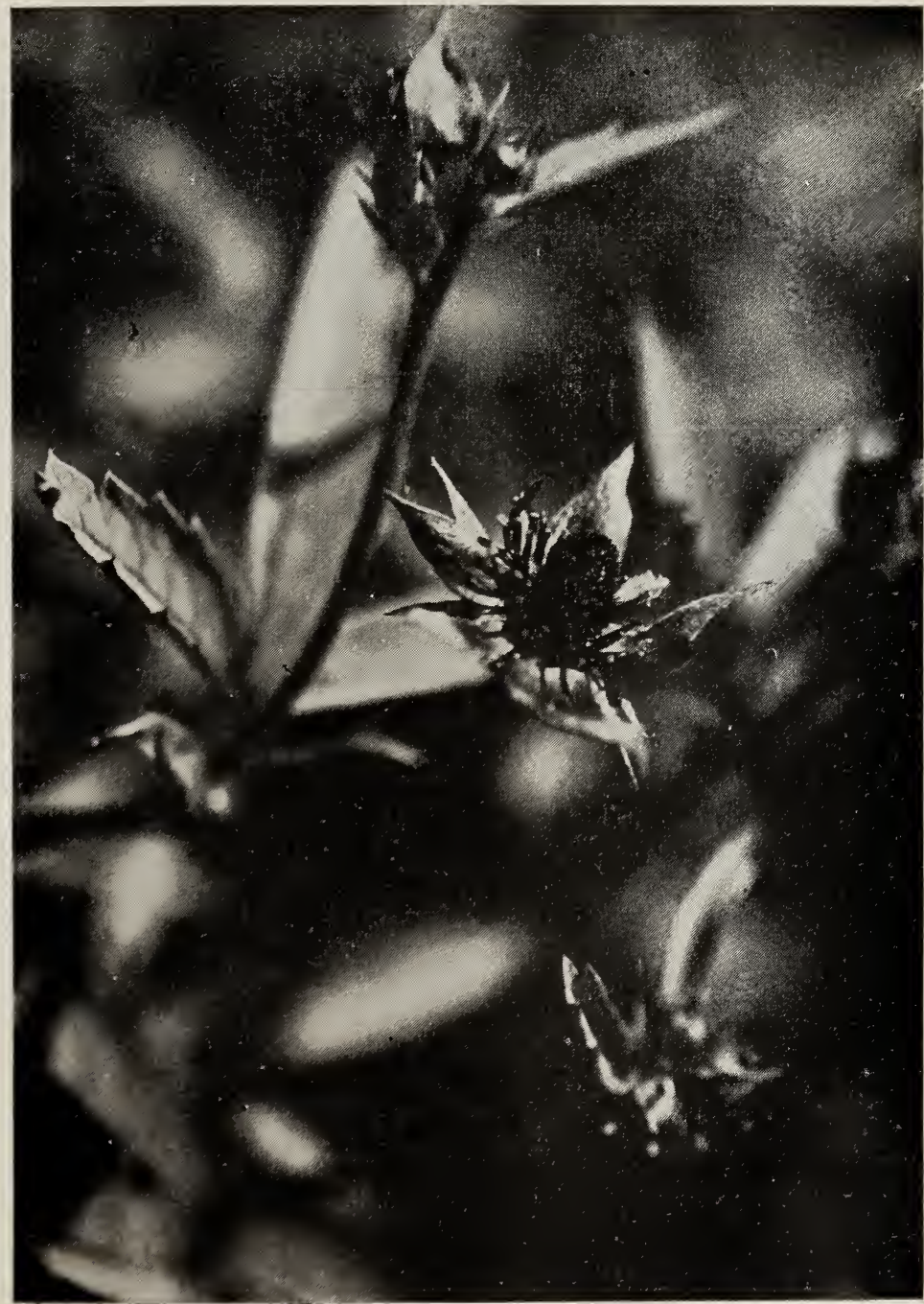

Marsh Cinquefoll

(Potentilla Comarum) (Flower purple)

Ord. Rosacea 


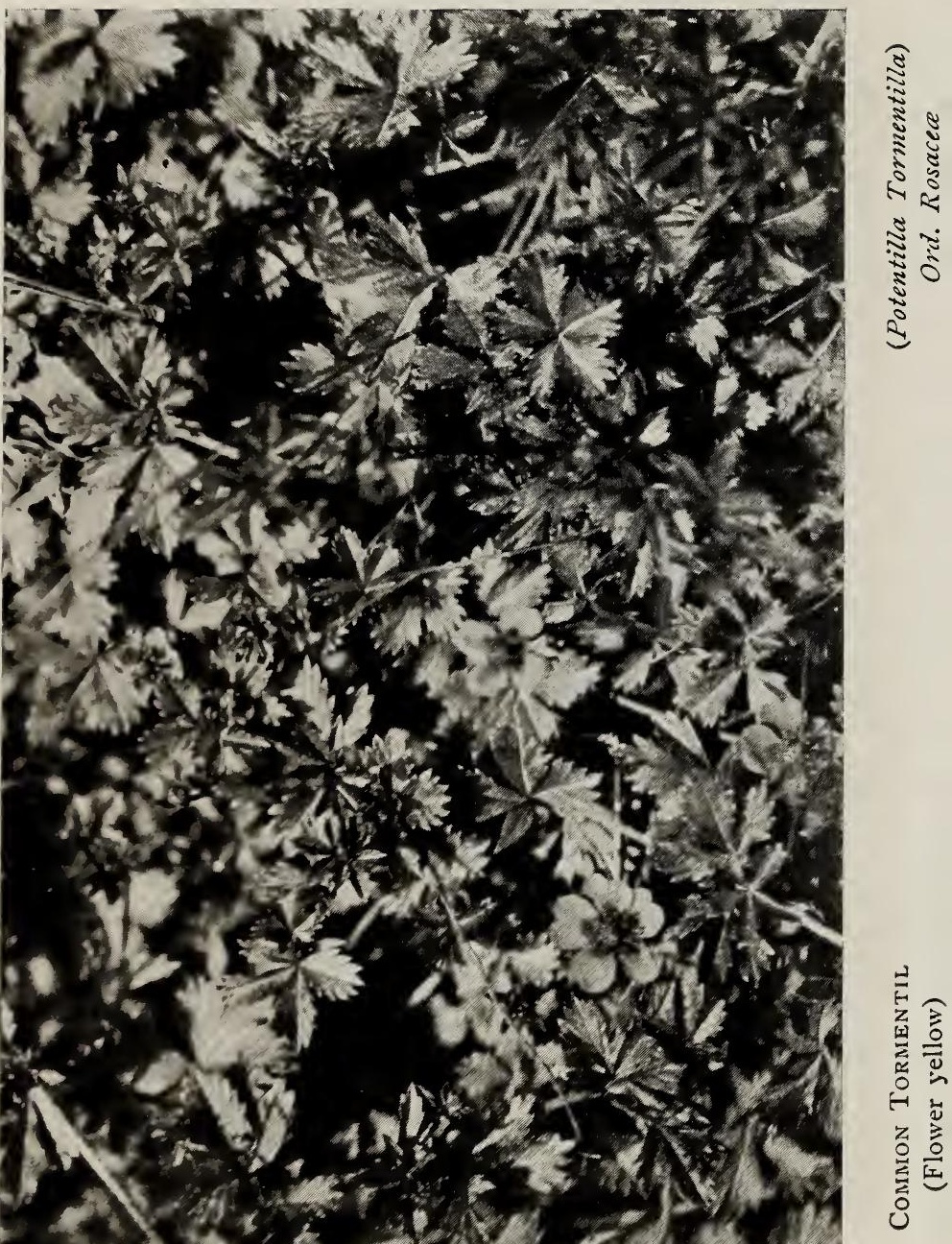




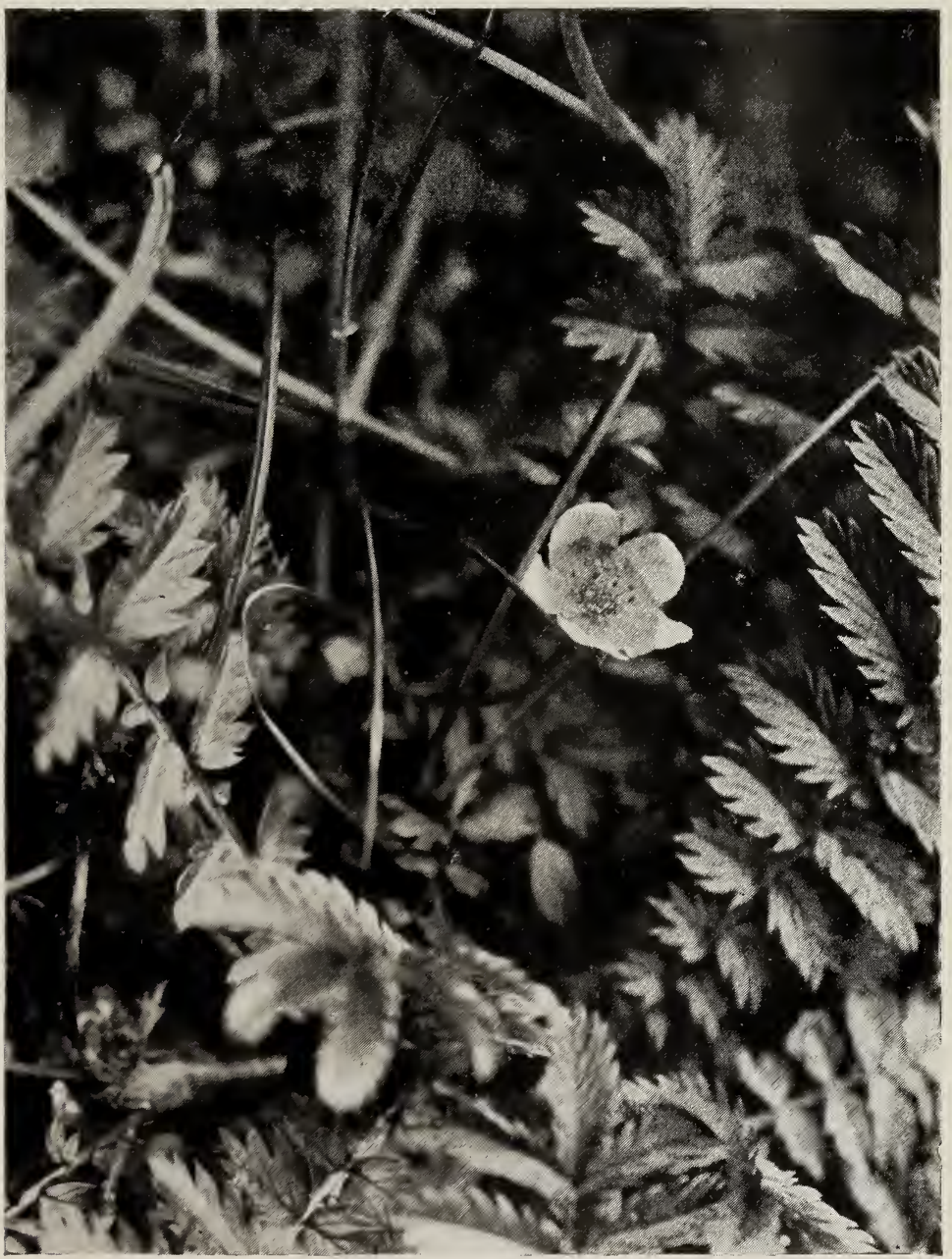

Silver Weed

(Flower yellow) 


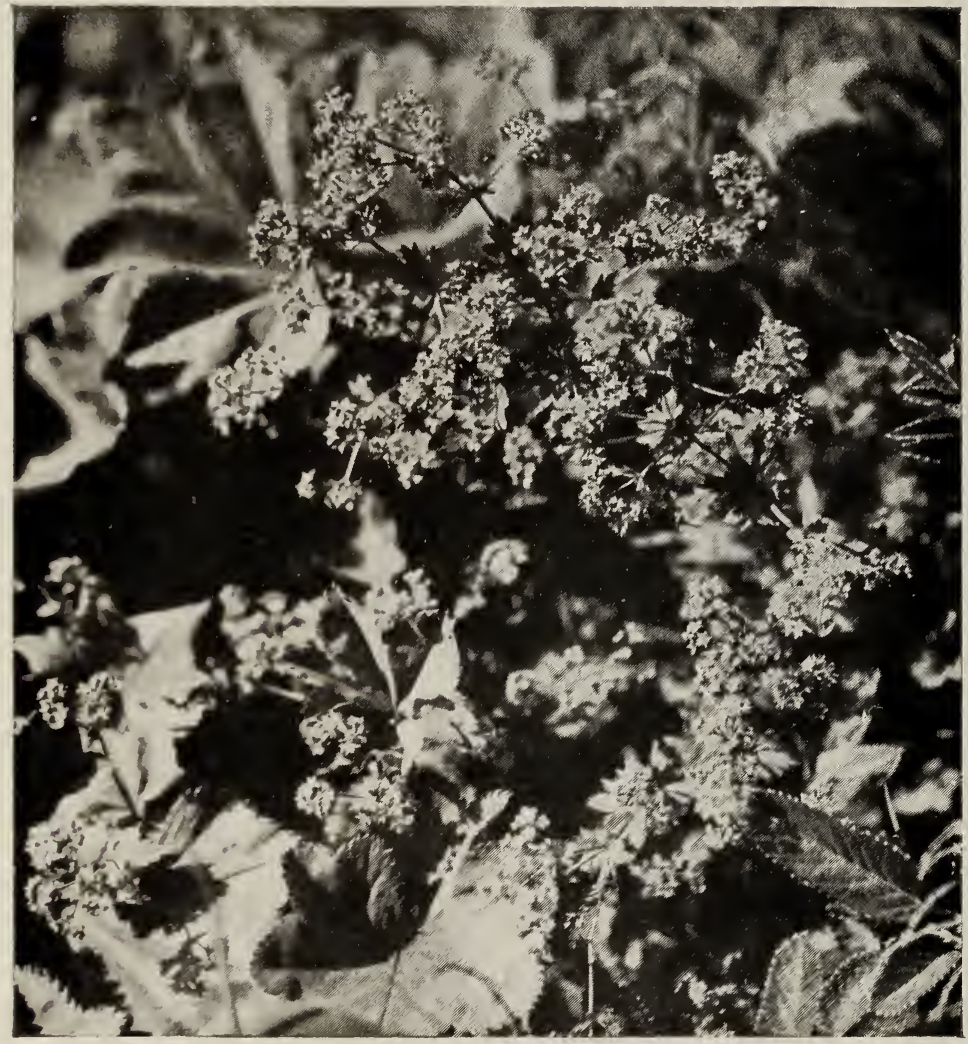

Common T.ady's Mantle

(Alchemilla vulgaris) (Flower greenish yellow) Ord. Rosacea 


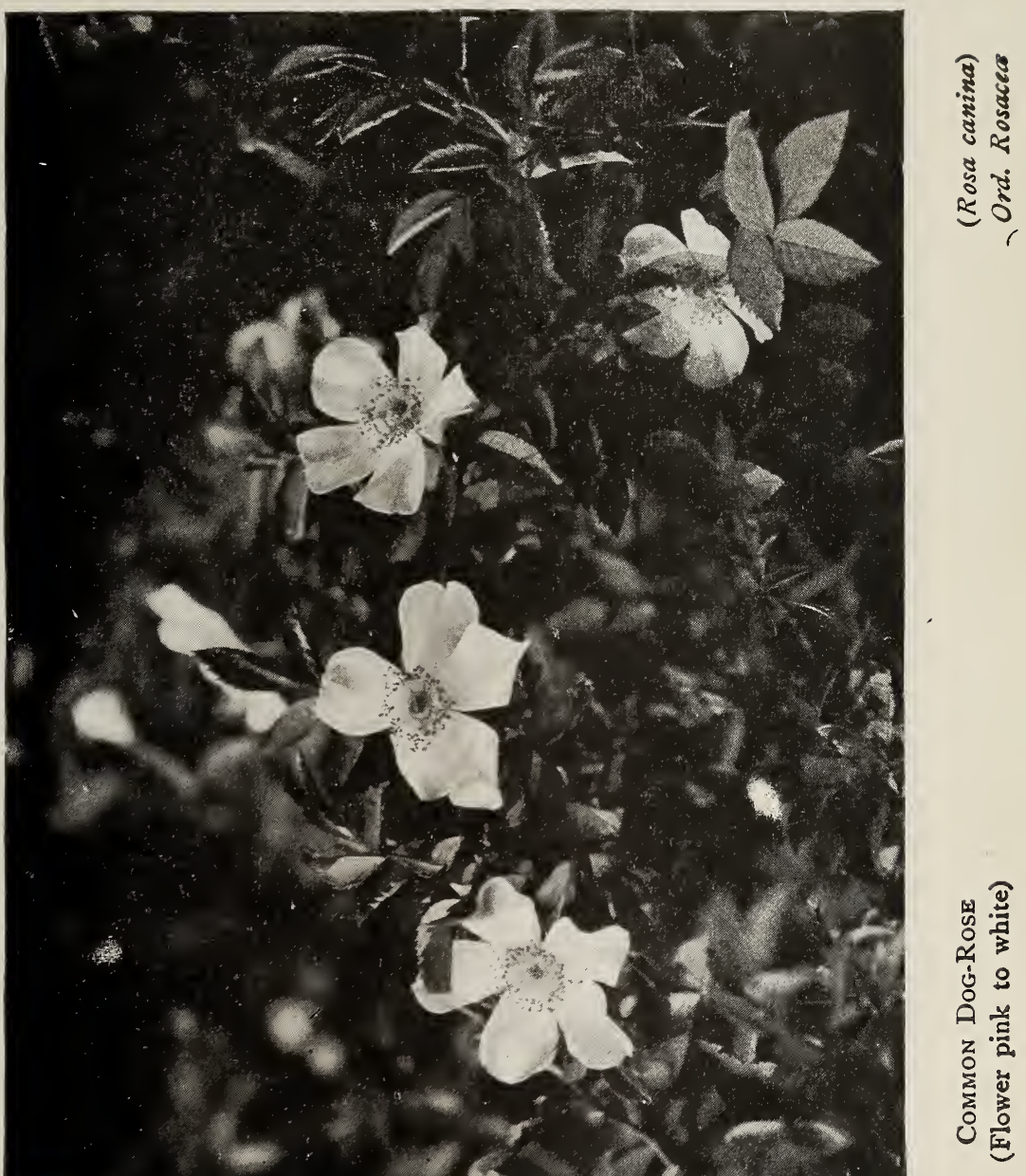




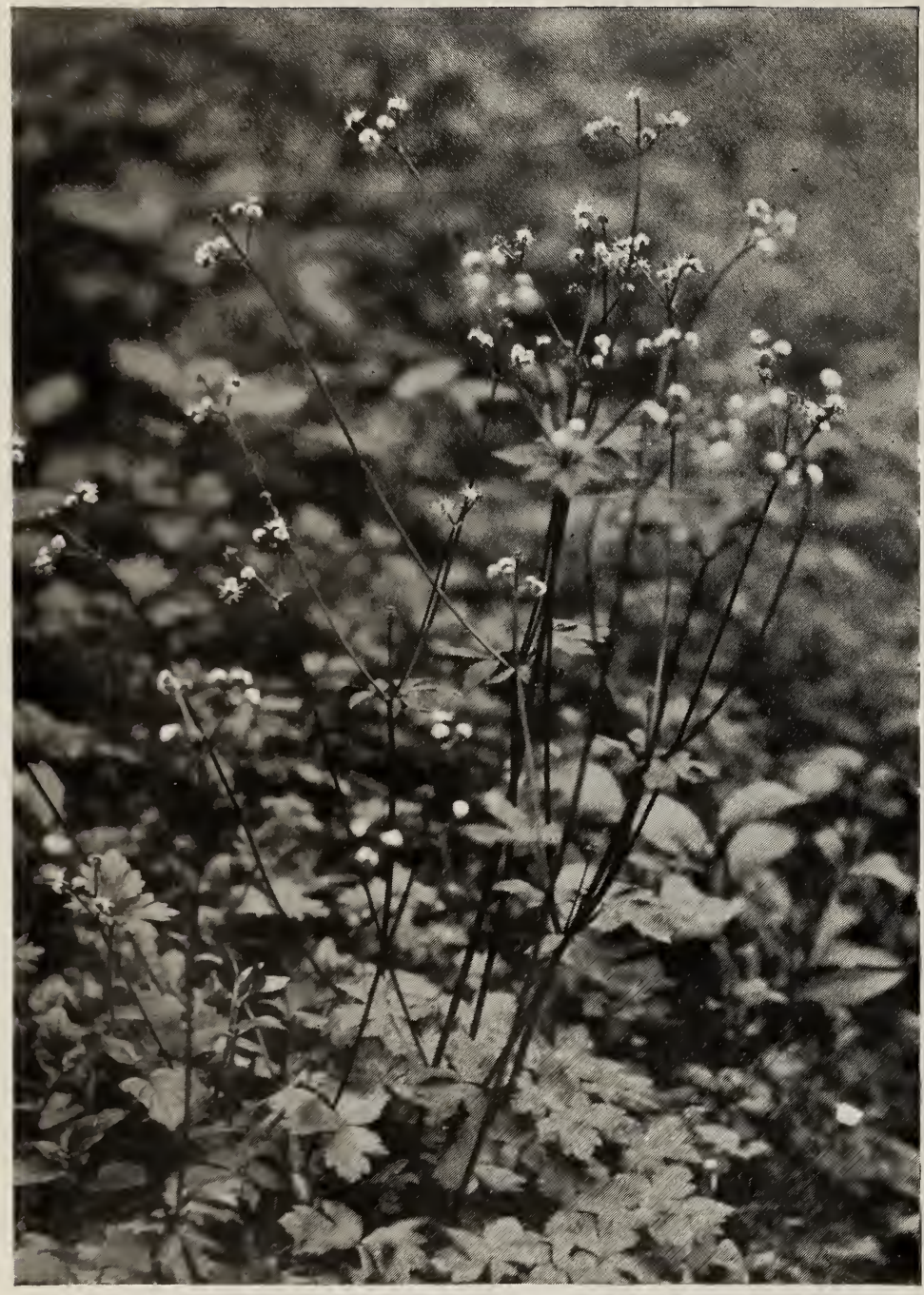

WoOd Sanicle

(Sanicula europaea)

(Flower white)

an

Ord. Umbelliferce 


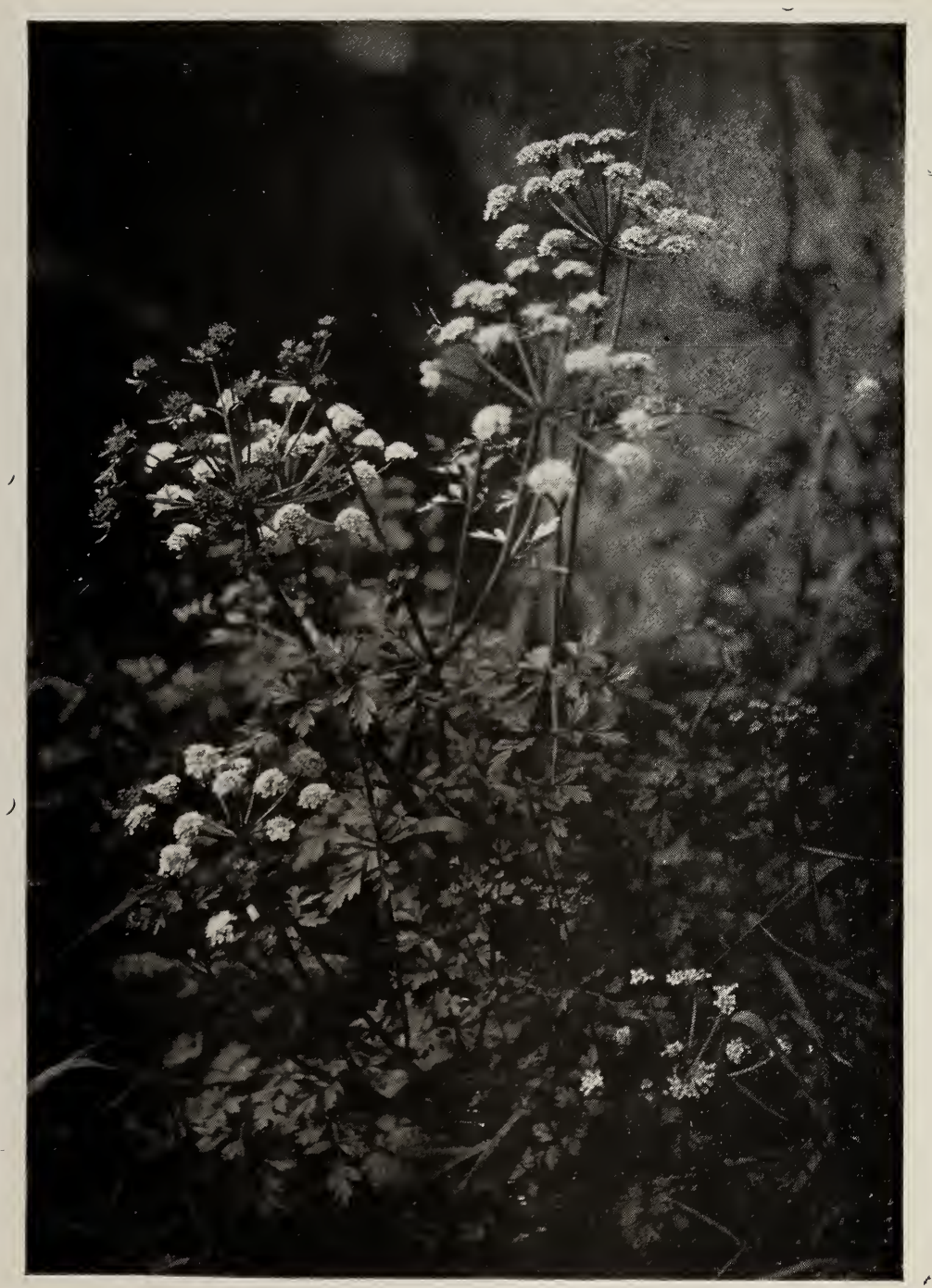

Hemlock Water-Dropwort

(Enanthe crocata) (Flower white) Ord. Umbelliferce 


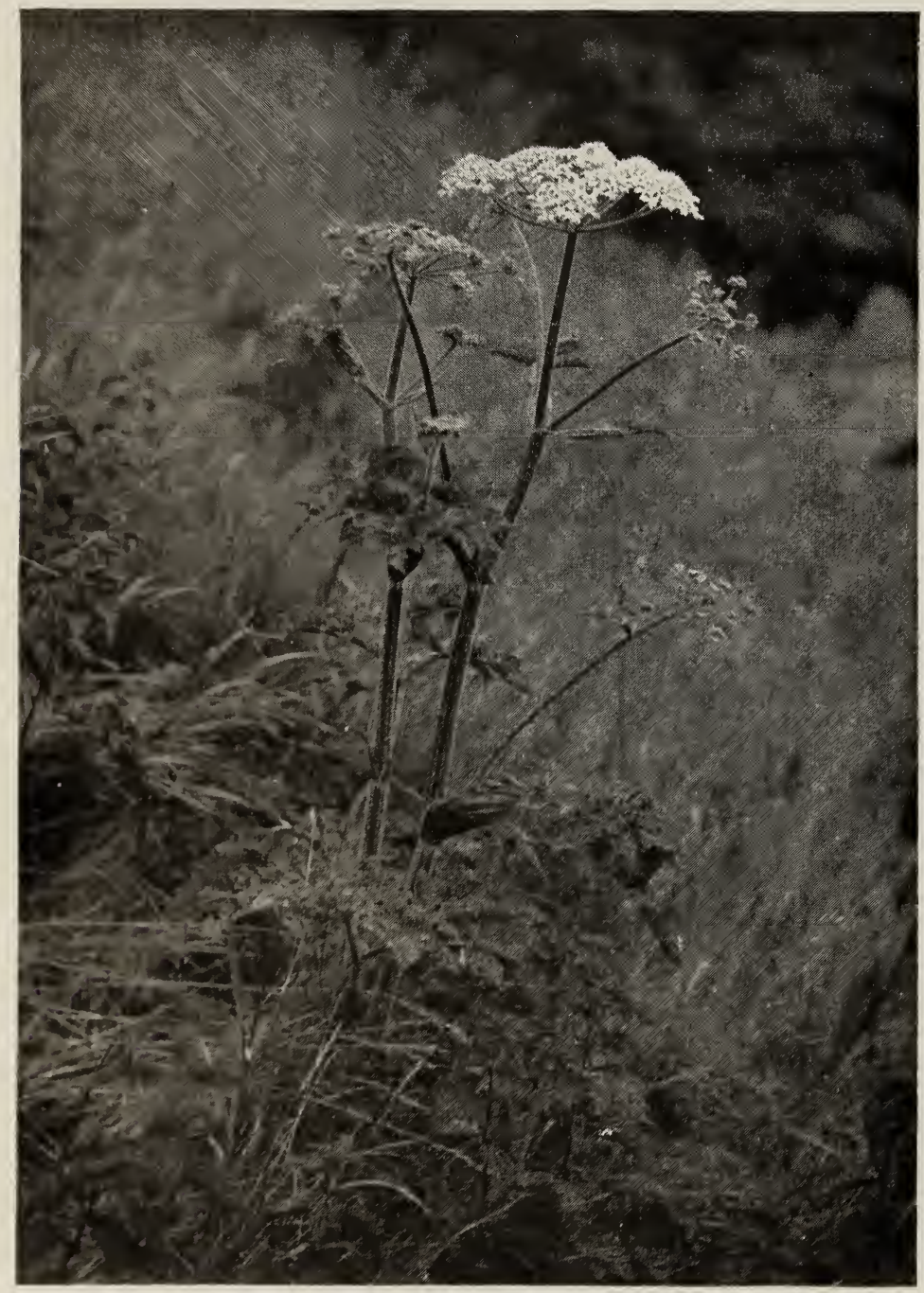

COMmon Cow-Parsnip (Flower white or pinkish white)
(Heracleum Sphondylium) Ord. Umbellifera 


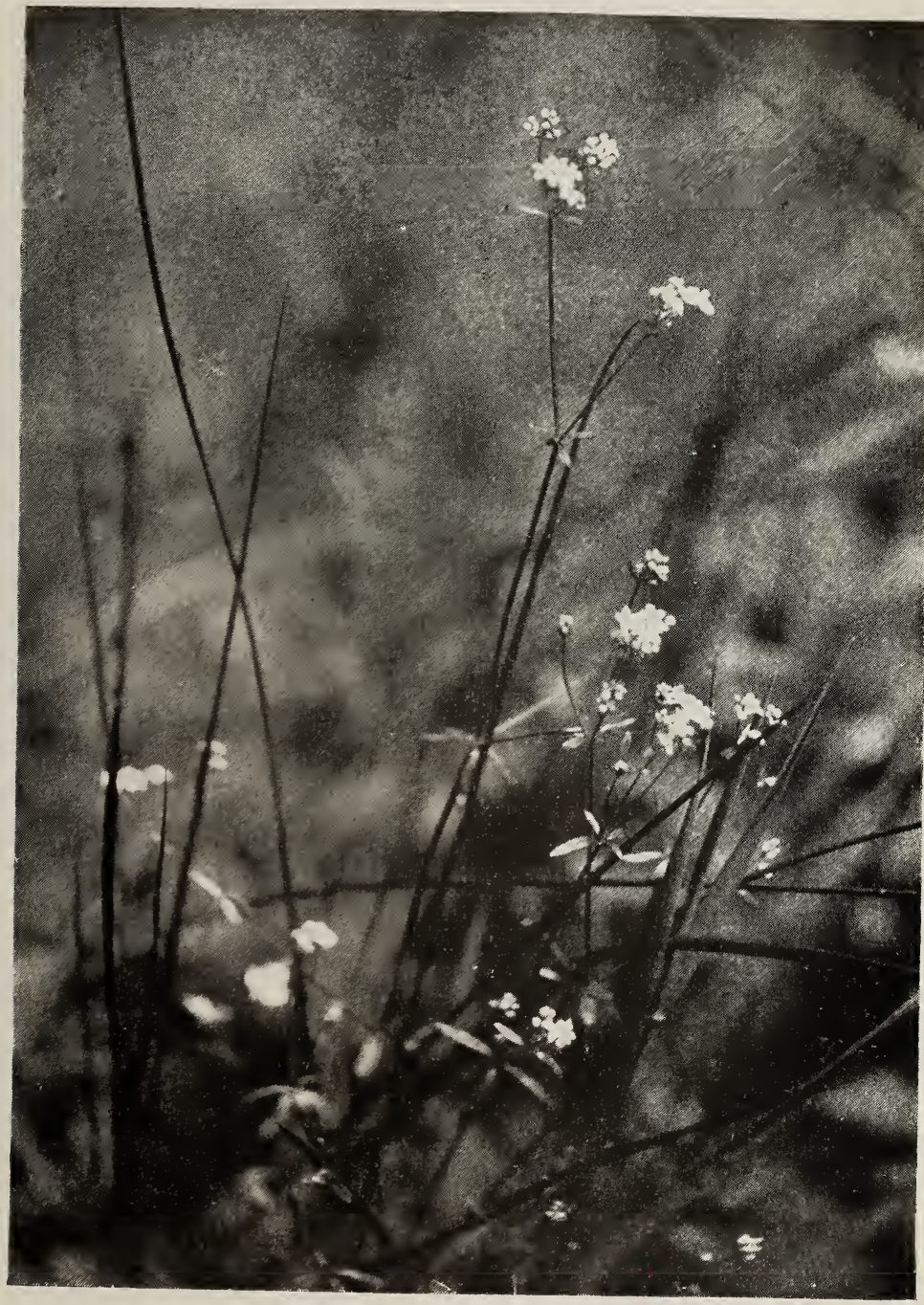

White Water-Redstraw (Flower white) 


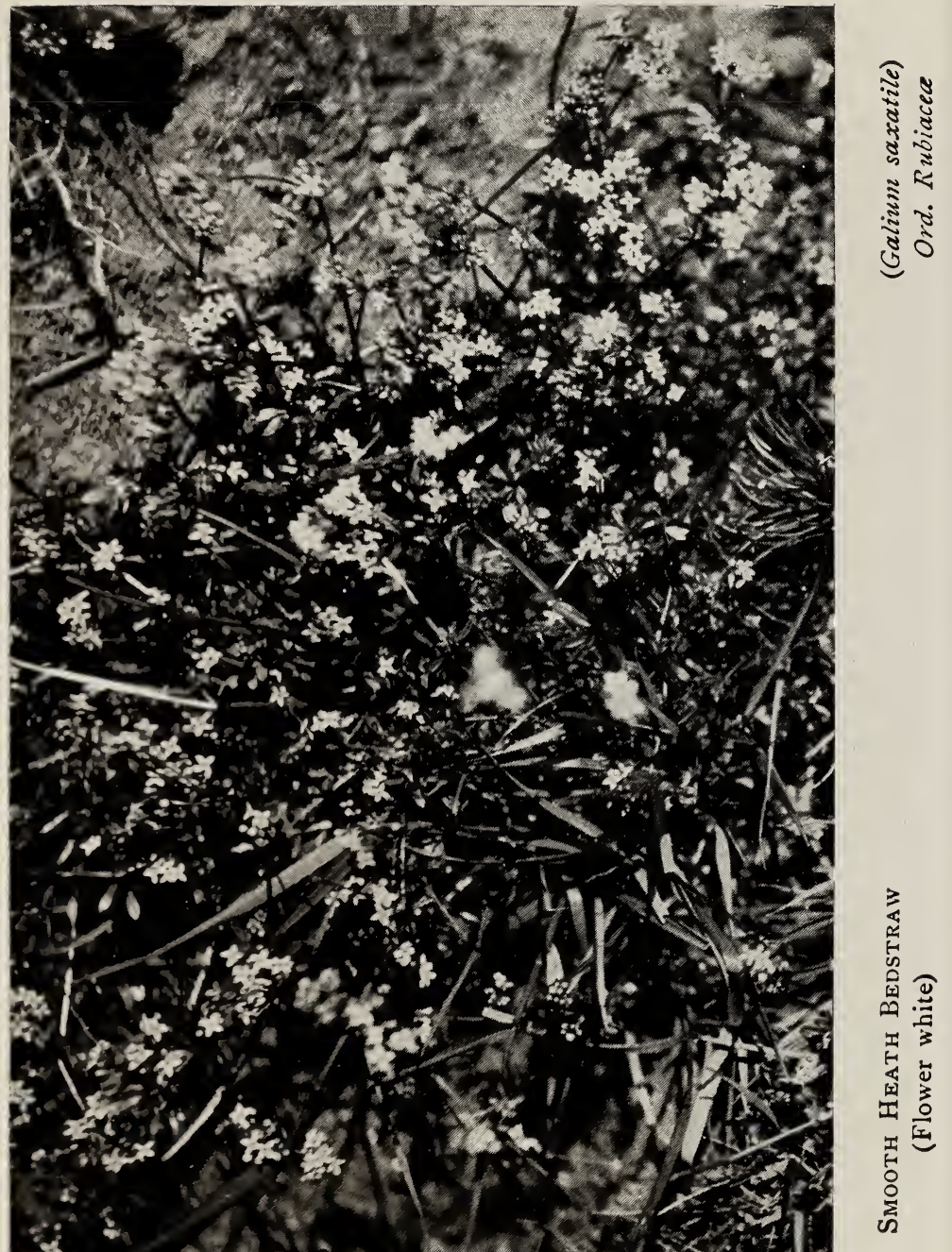




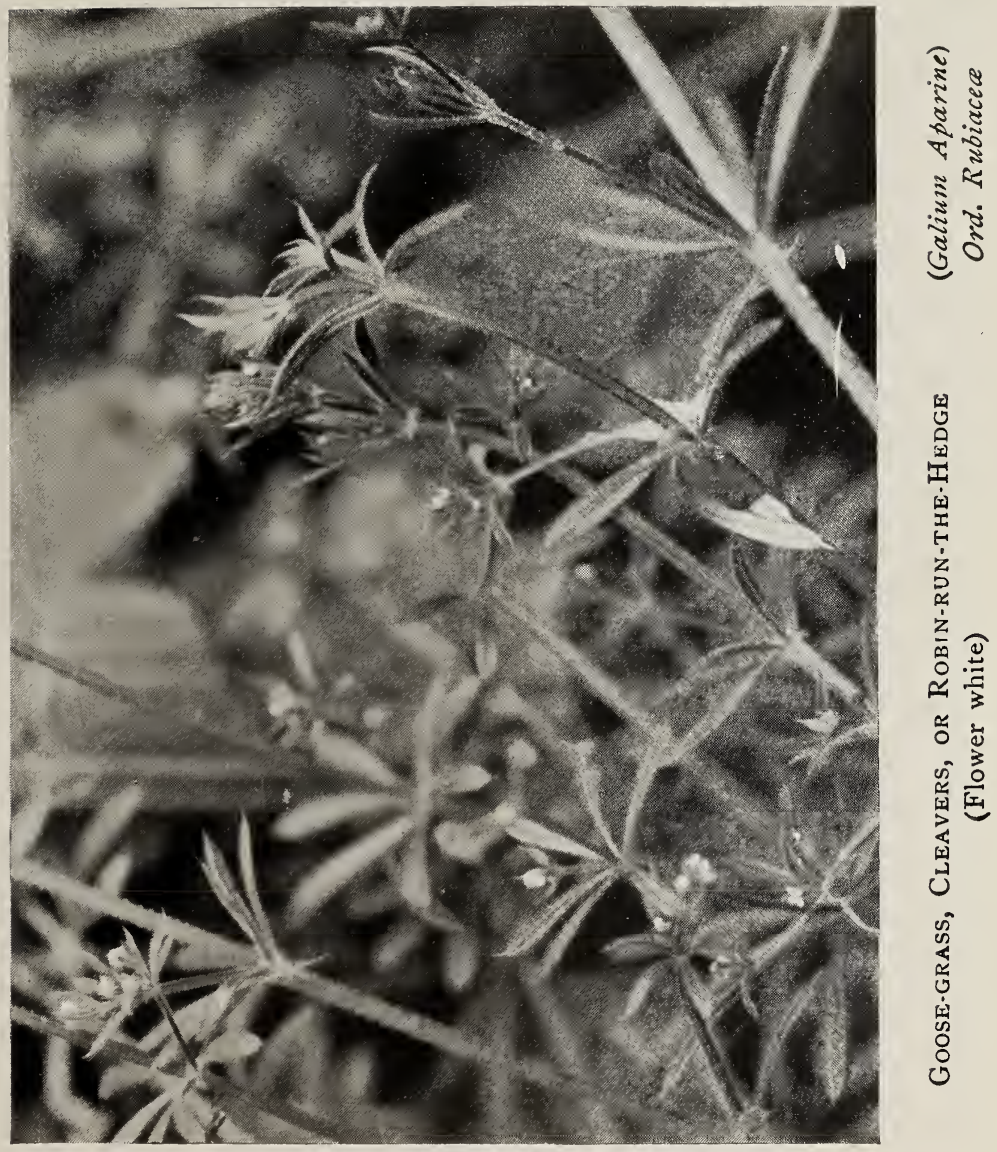




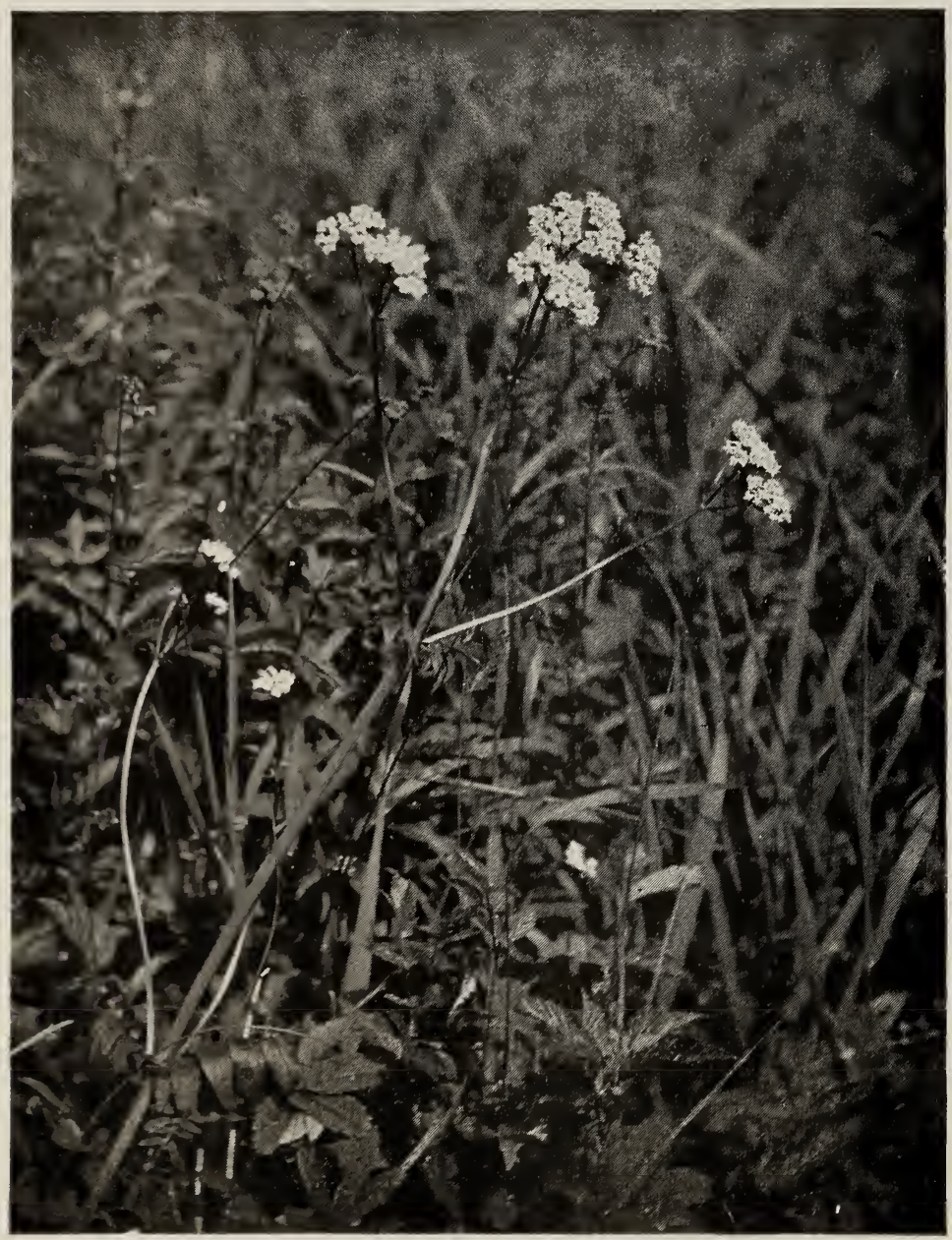

Great Wild, or Cat's Valerian (Flower pale purple)

(Valeriana officinalis) Ord. Valerianea 


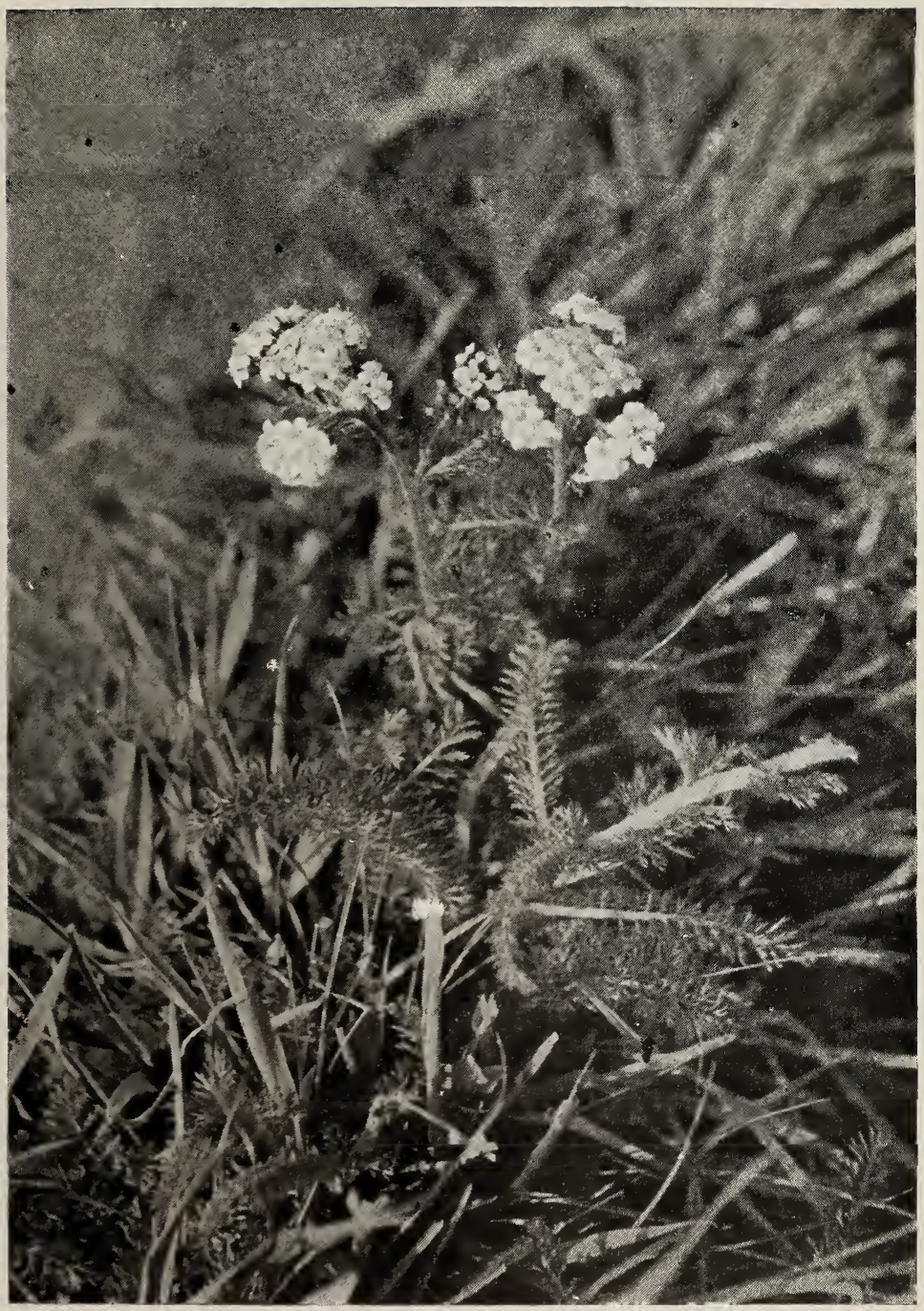

COMMON YARROW OR MILFOIL

(Flowers white, sometimes pink)

(Achillea Millefolium)

Ord. Composita 


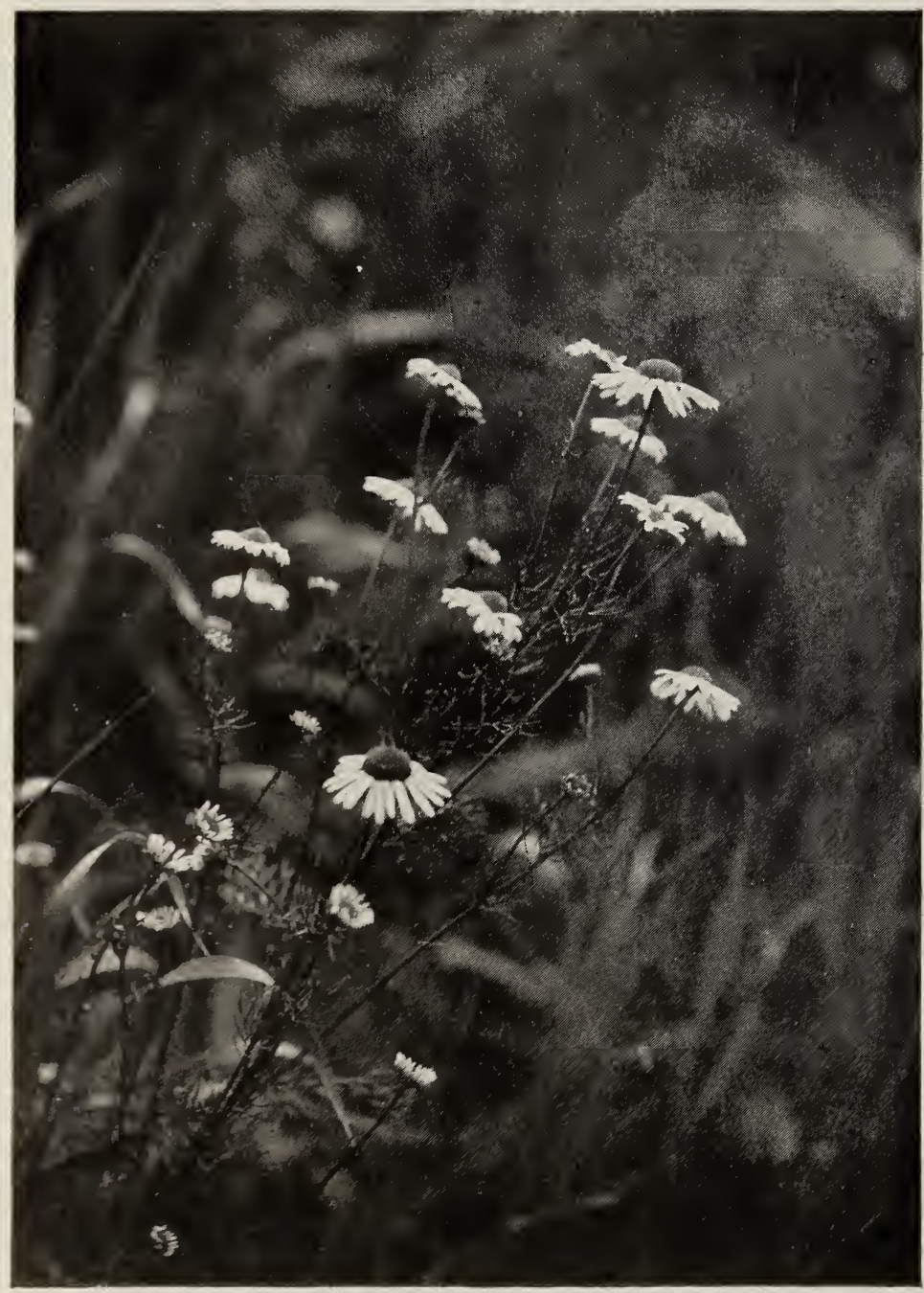

Scentless Mayweed

(Flower white, with yellow disc)

(Matricaria inodora)

Ord. Composita 


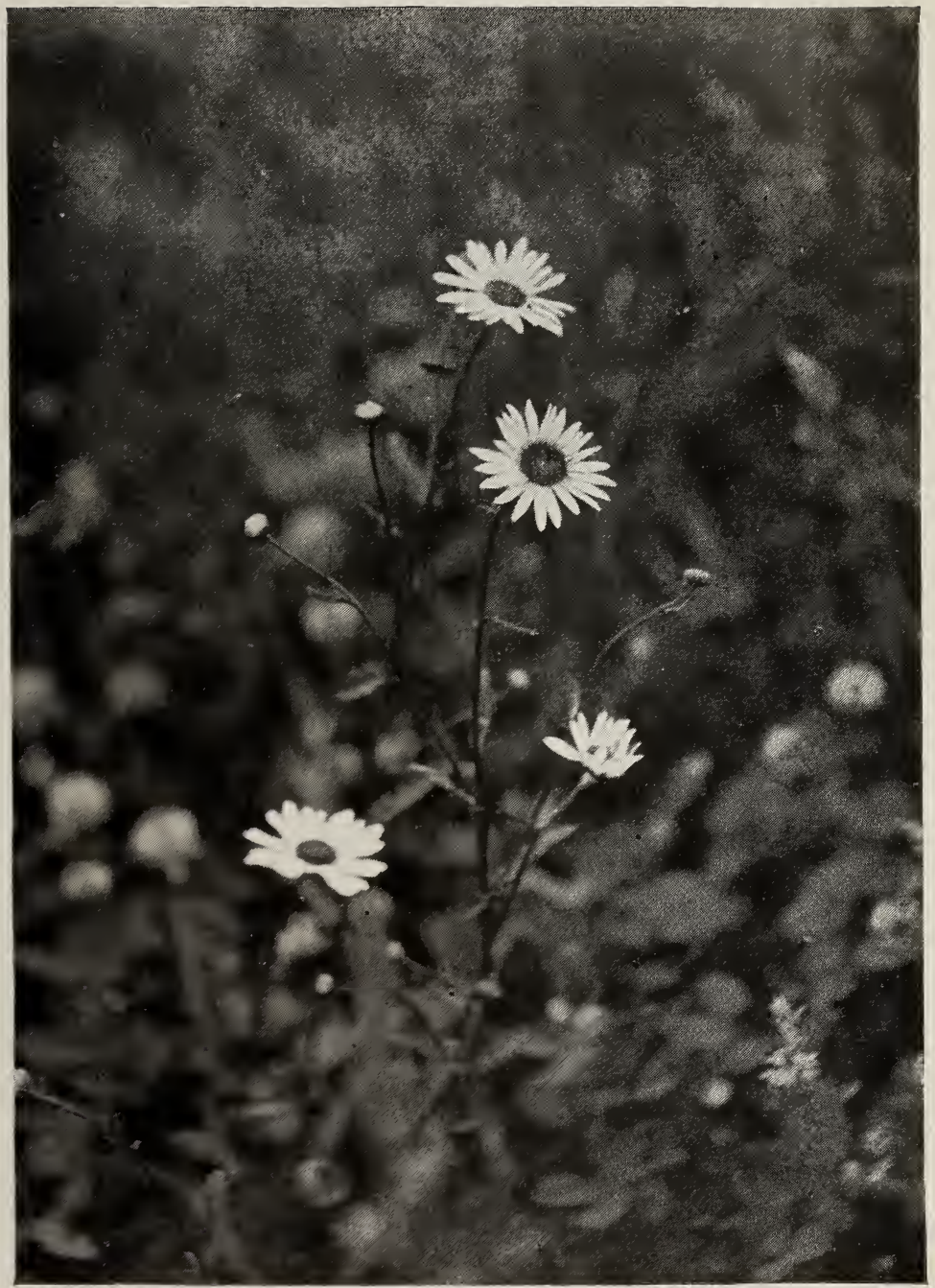

Great White Ox-eye

(Chrysanthemum Leucanthenum) (Flower white, with yellow disc) Ord. Compositce 


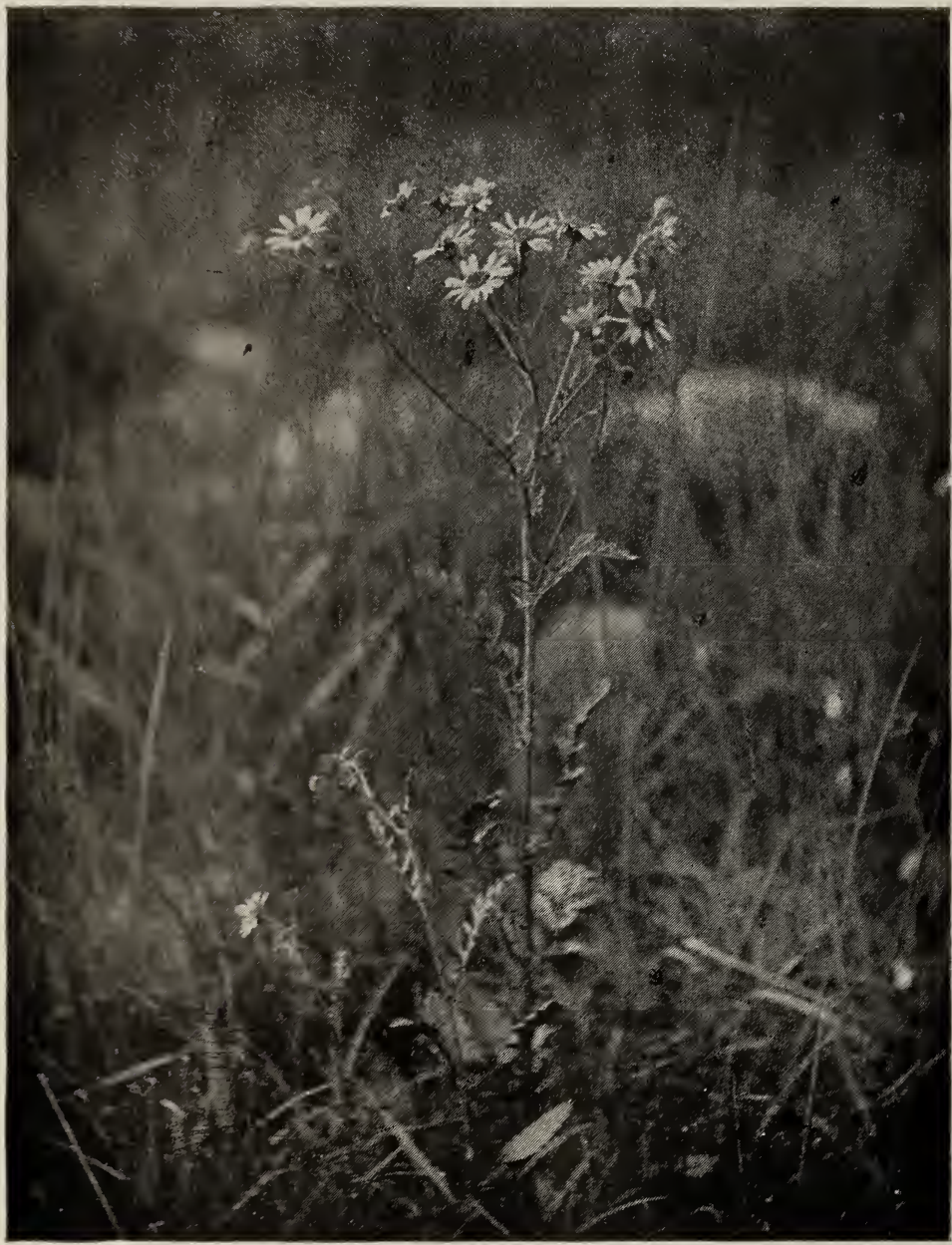

COMMON RAGWORT (Flower yellow)

(Senecio Jacobaea) Ord. Composite 


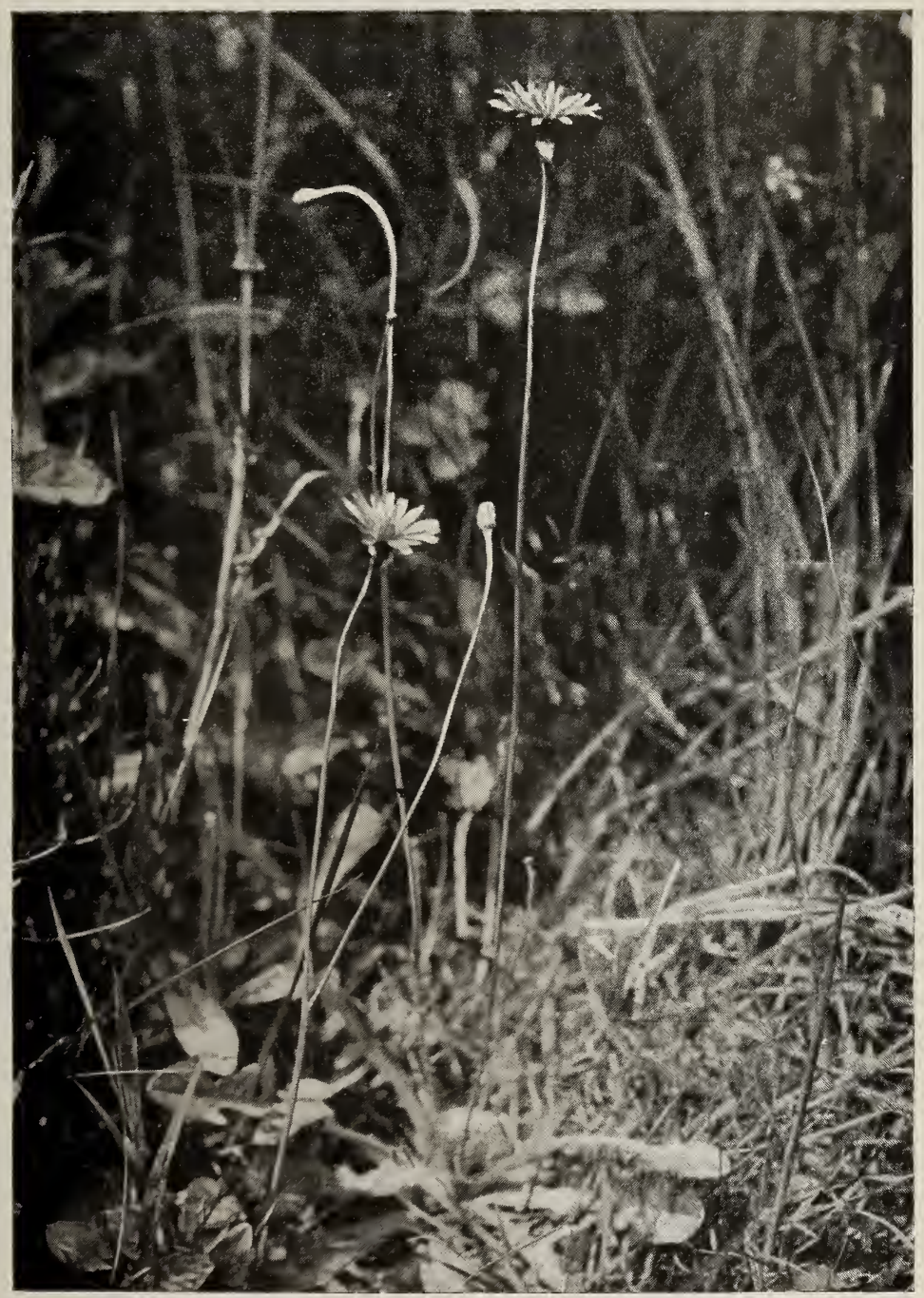




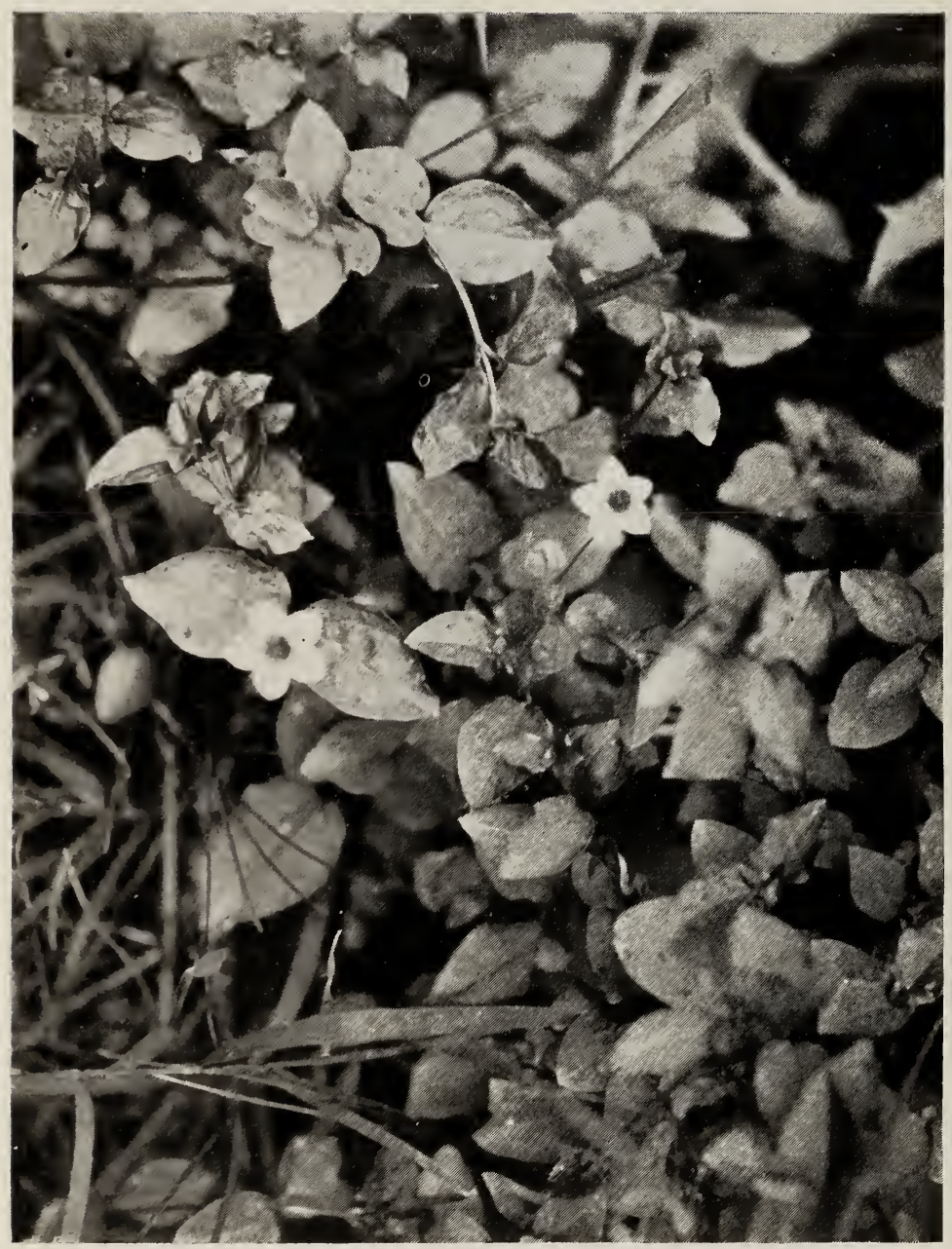




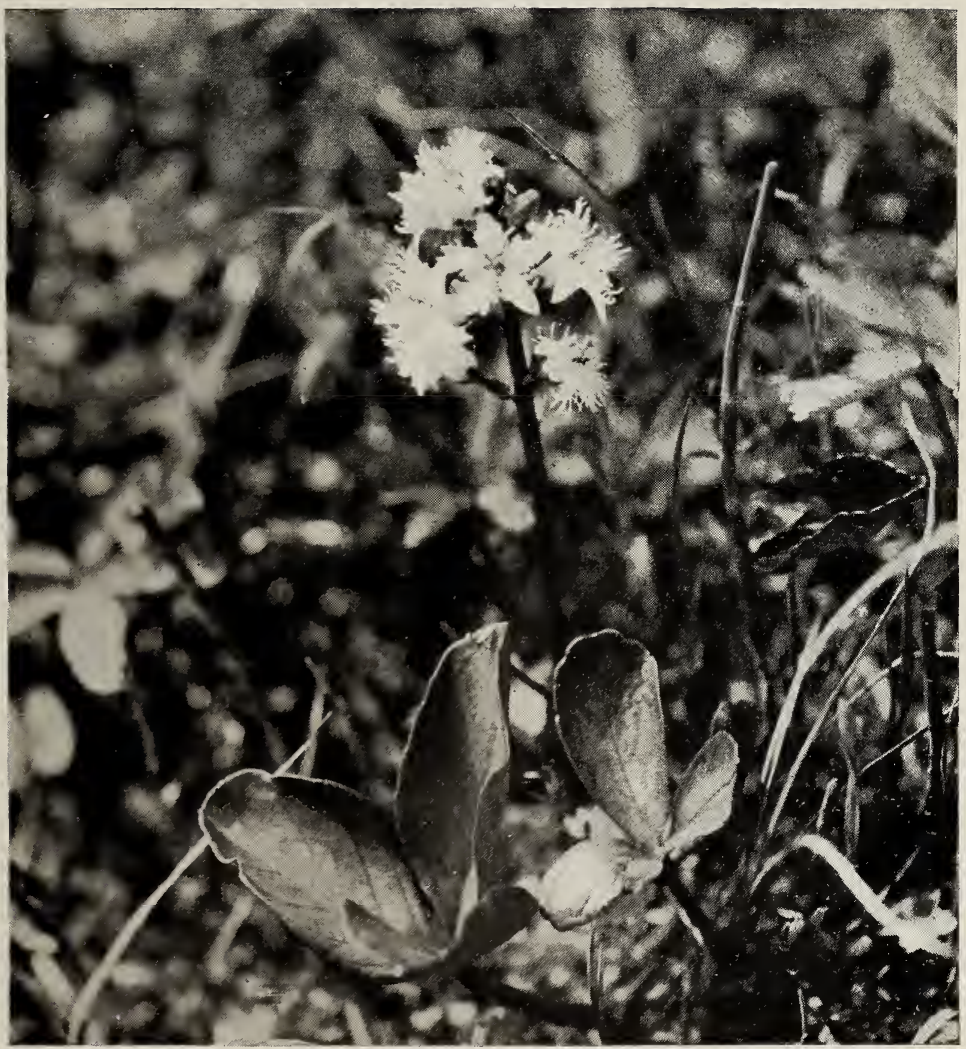

Buckbean or Marsh-TrefoIL

(Flower white, tinged with pink)

(Menyanthes trifoliata) Ord. Gentianea 


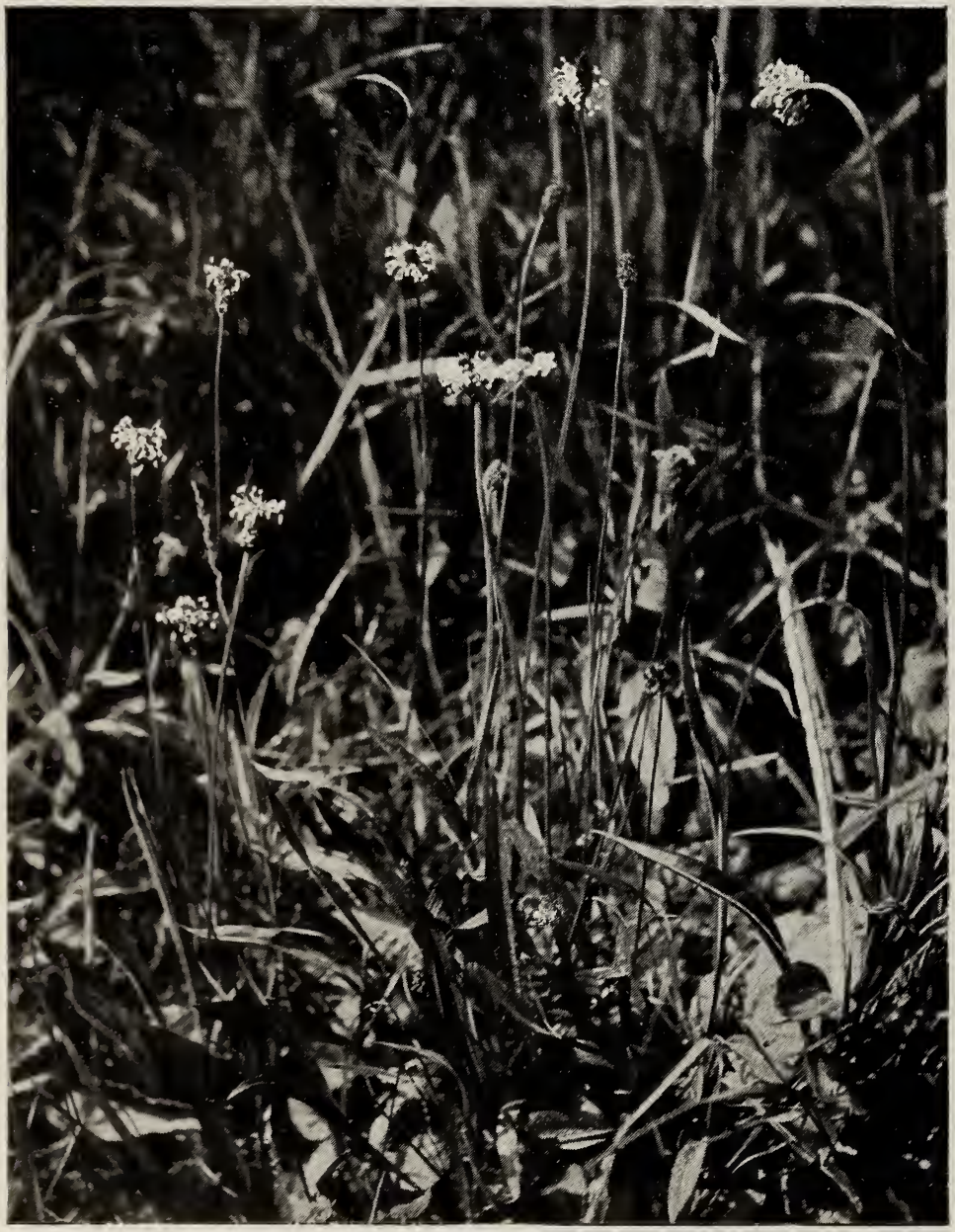

Ribwort Plantain

(Plantago lanceolata) Ord. Plantaginea 


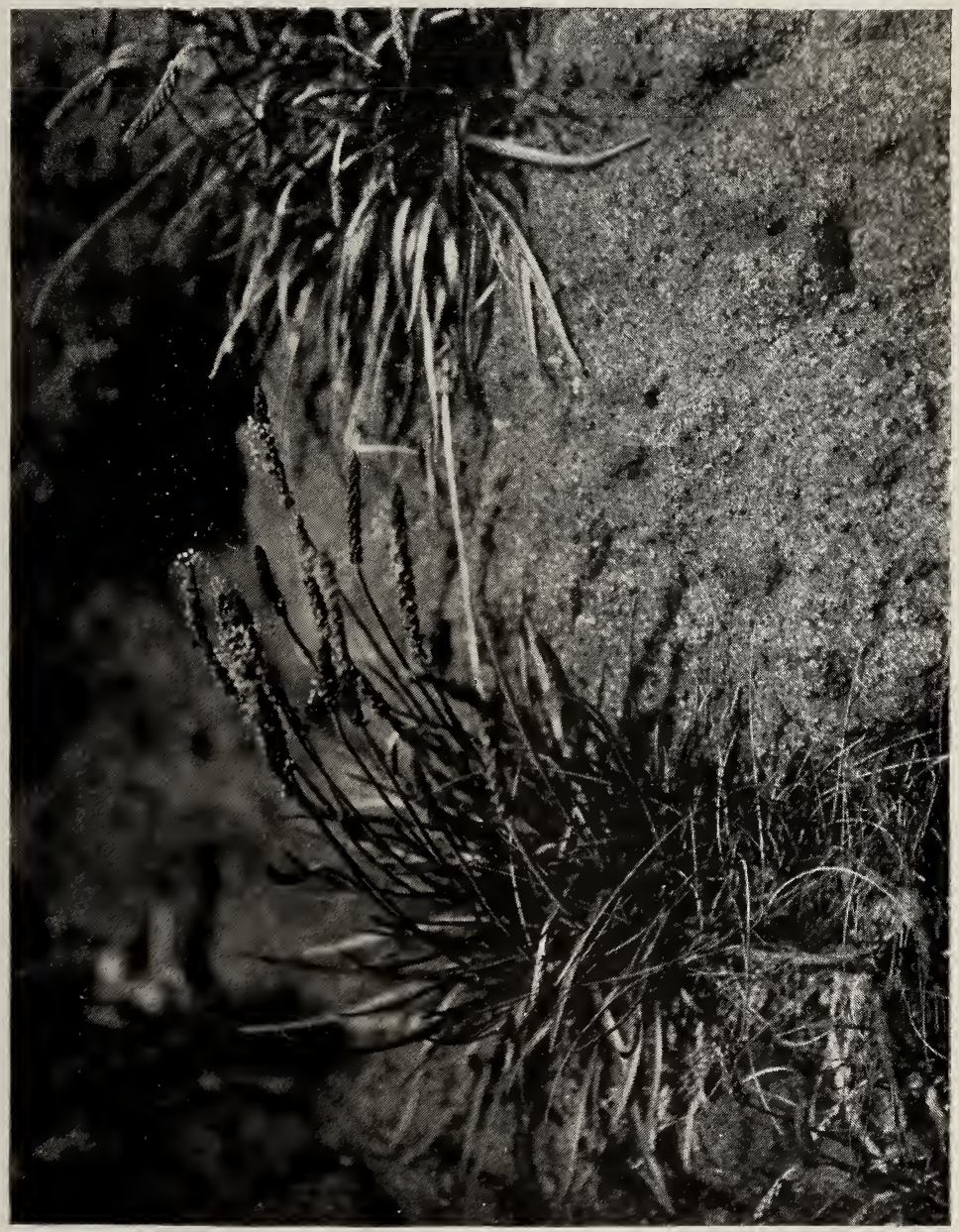

Seaside Plantain

(Planiago maritima)

Ord. Plantaginea 


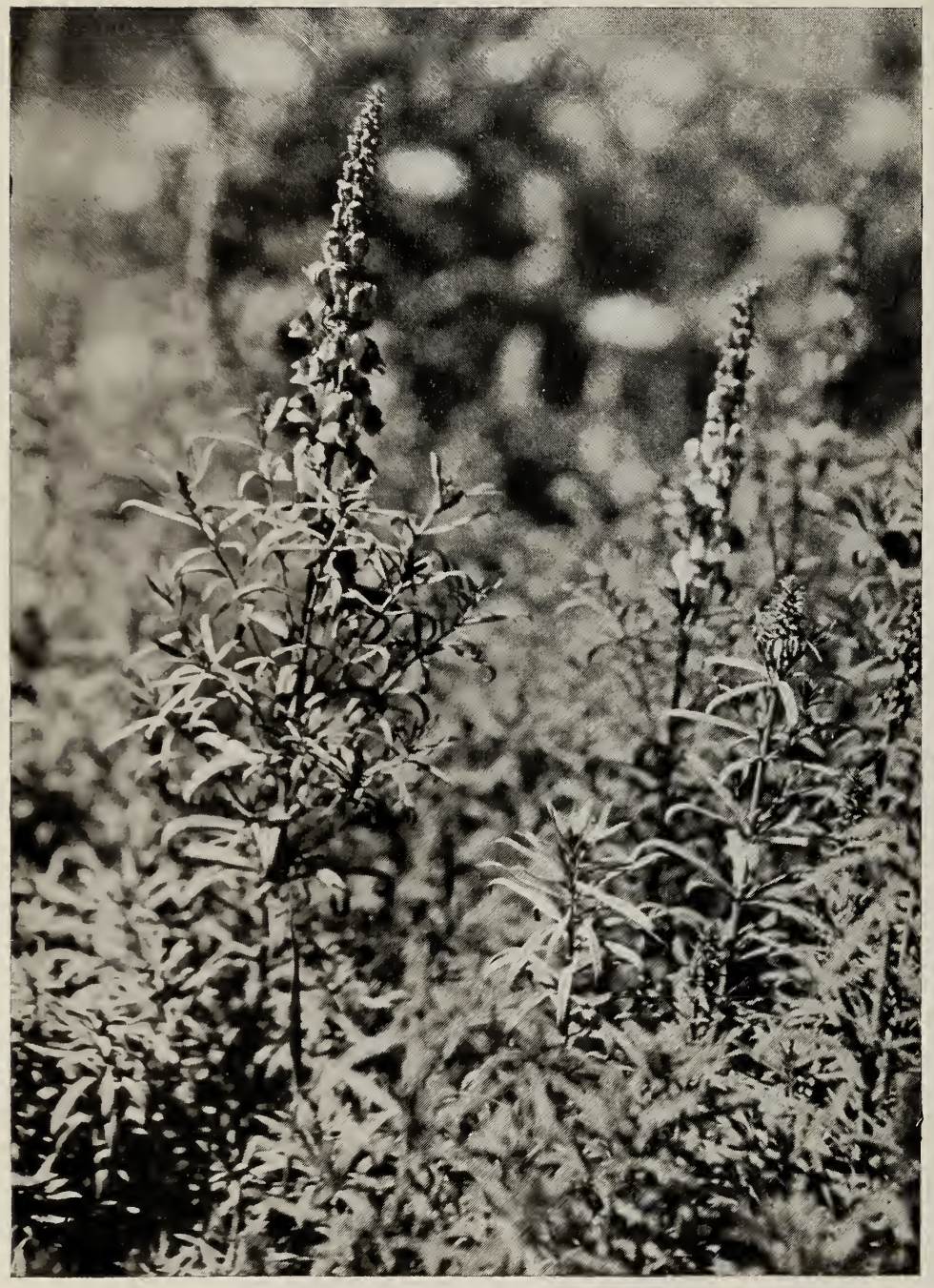

Yellow Toadflax

(Flower yellow, with orange lower lip)
(Linaria vulgaris)

Ord. Scrophularinea 


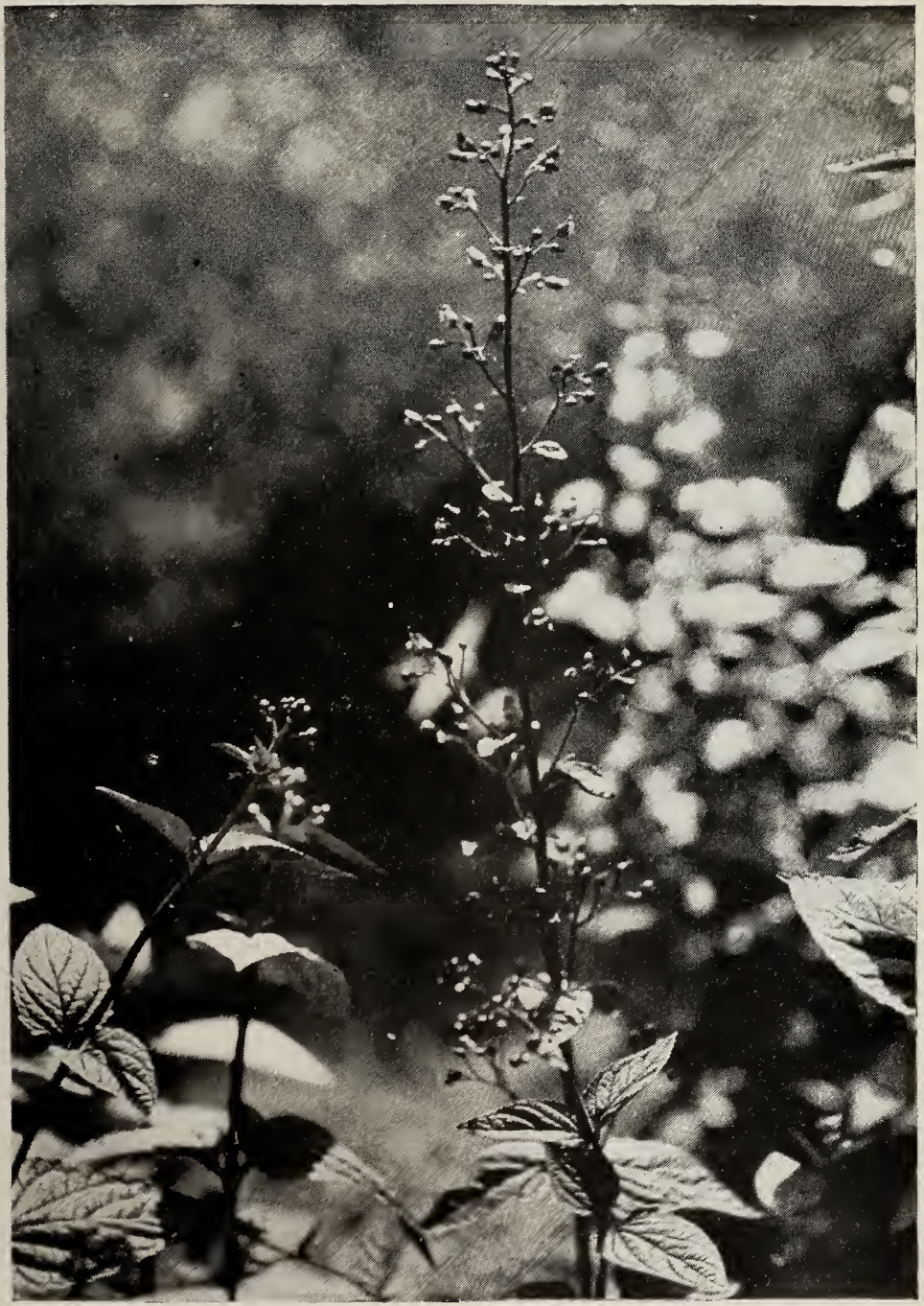

KNOTTED FigwORT

(Flower purple, mixed with greenish-yellow)
(Scrophularia nodosa) Ord. Scrophularinea 


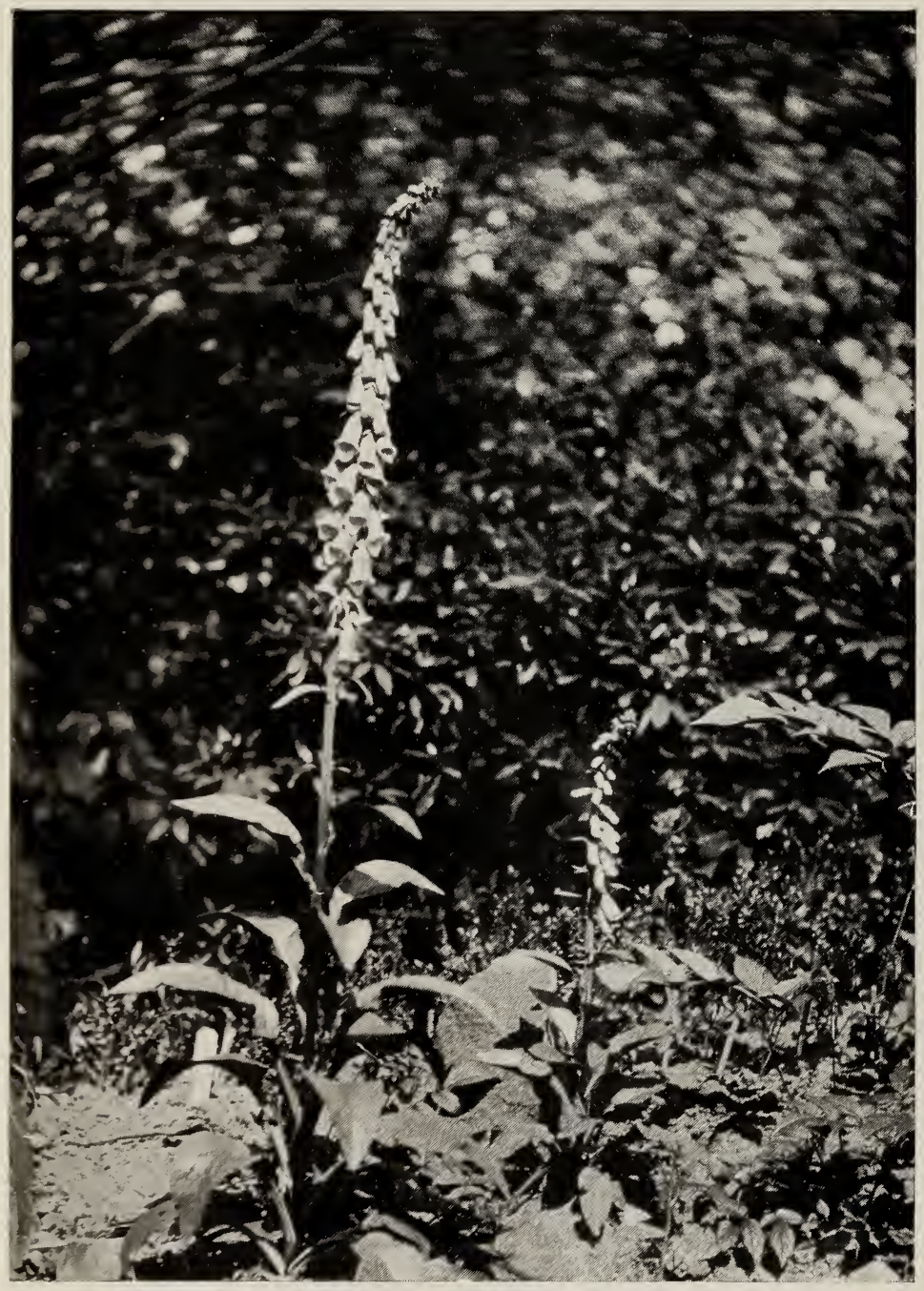

Purple Foxglove 


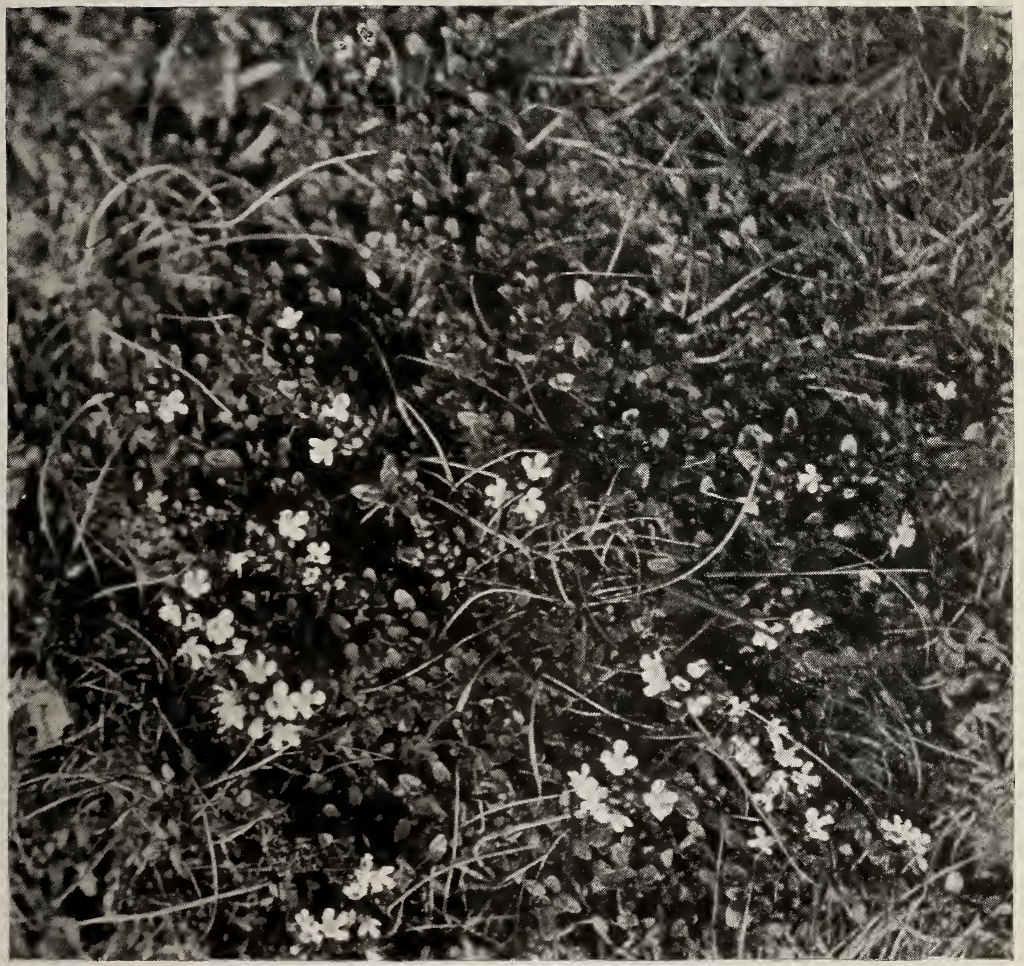

Wild Thyme

(Thymus Serpyllum)

(Flower light purple)

Ord. Labiate 


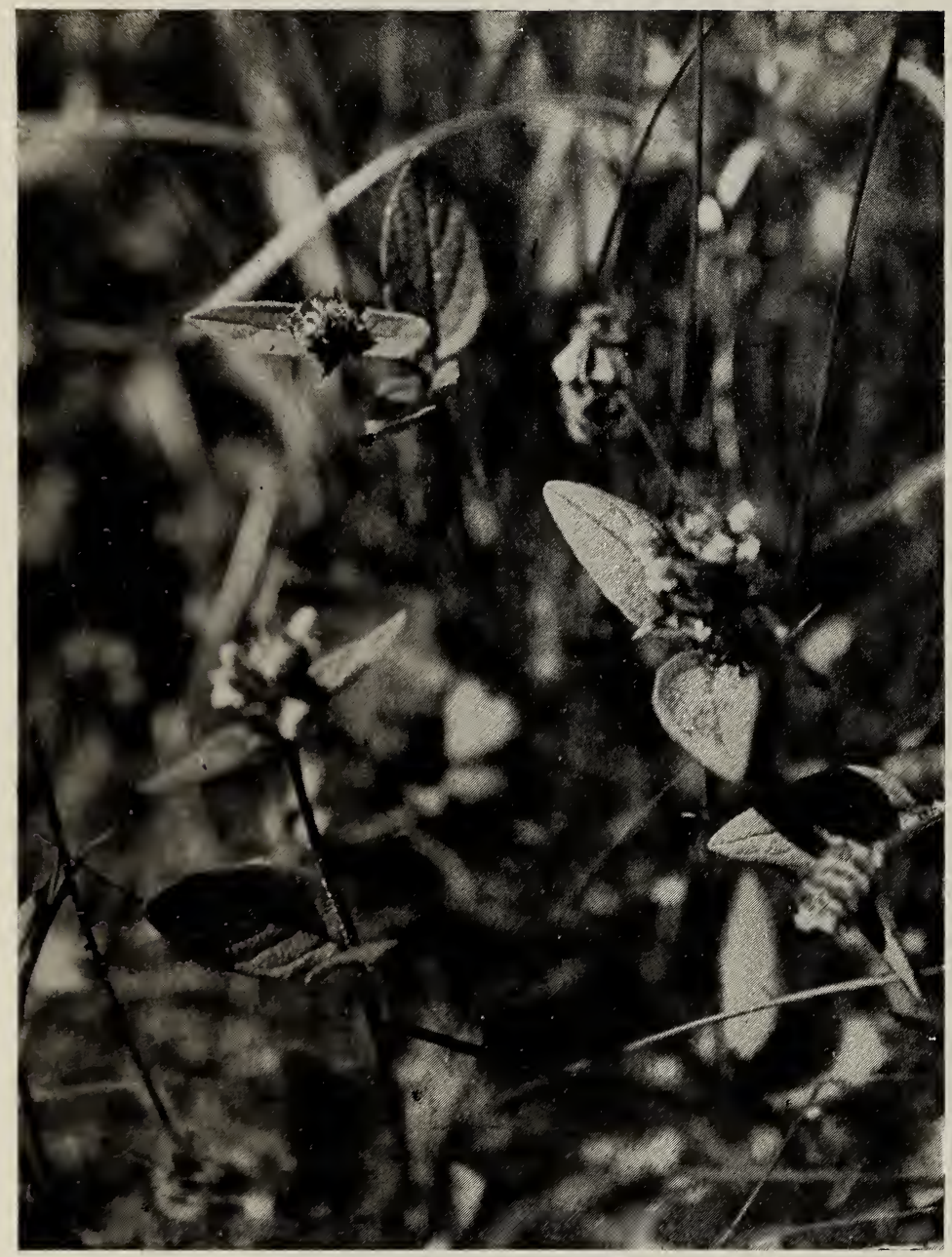

SELF-HEAL

(Flower blue, rarely white)
(Brunella vulgaris) Ord. Labiate 


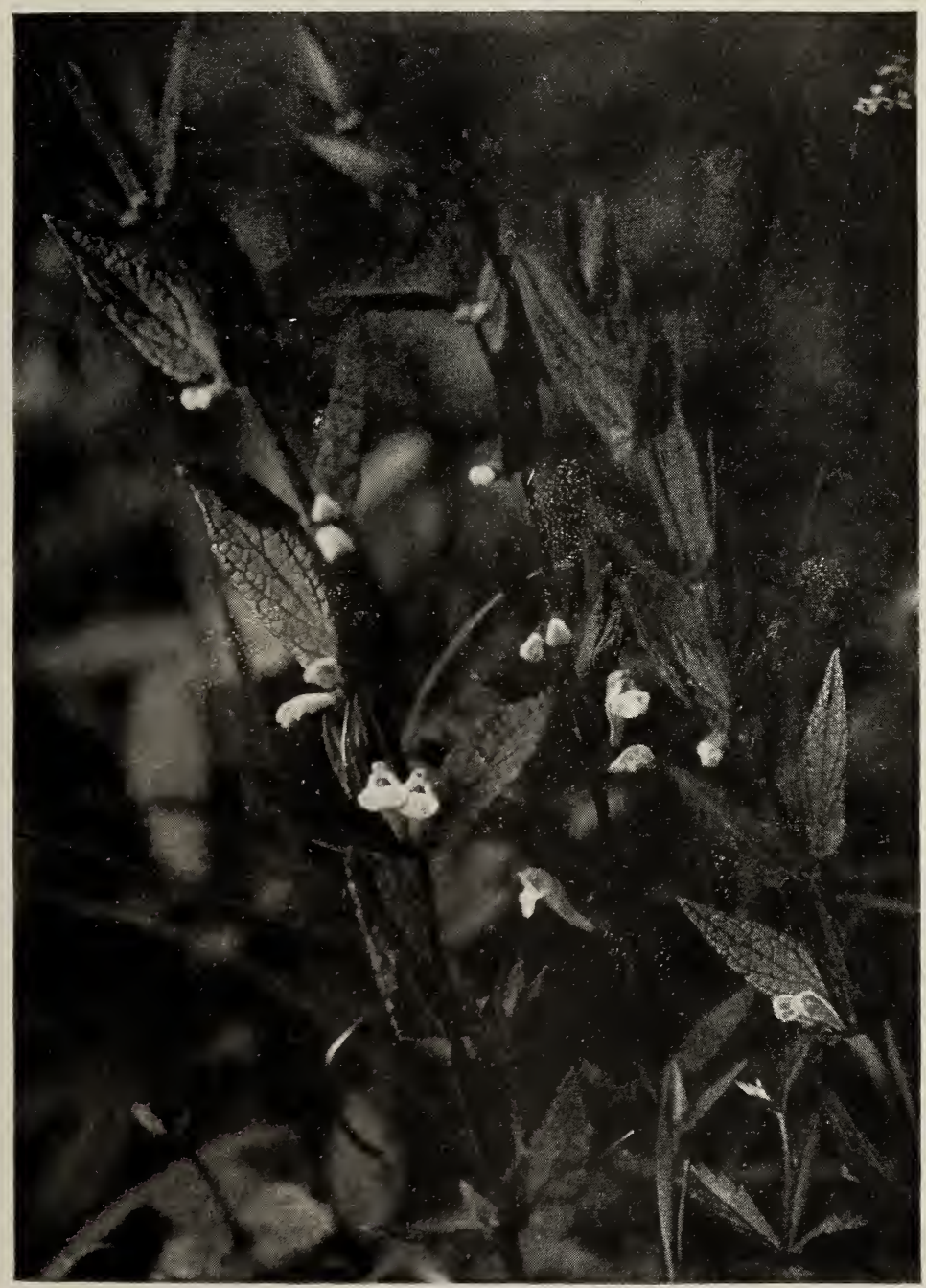

Common Skull-cap

(Flower blue)
(Scutellaria galericulata)

Ord. Labiate 


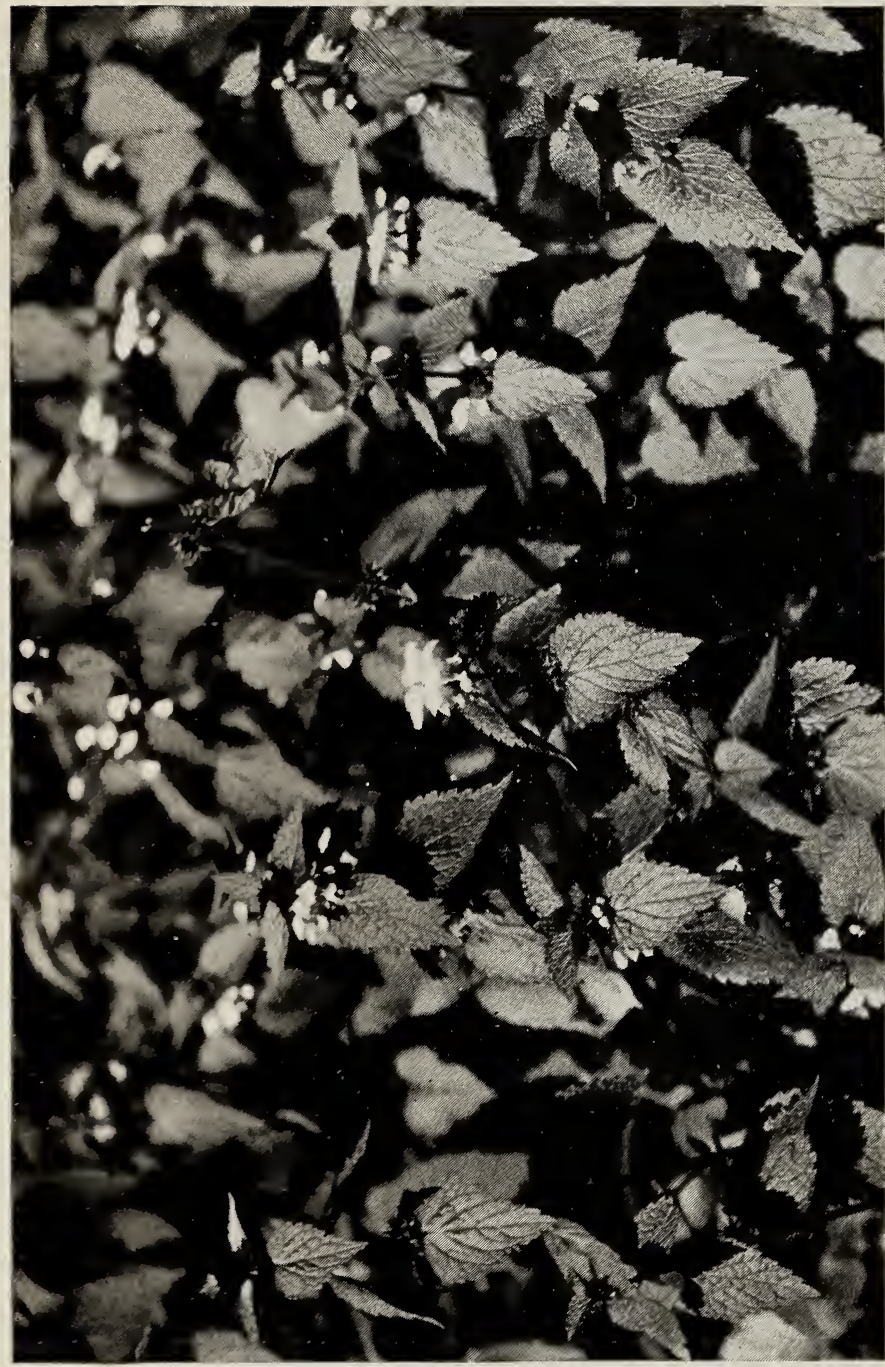

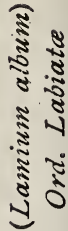

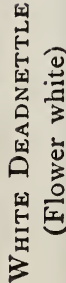




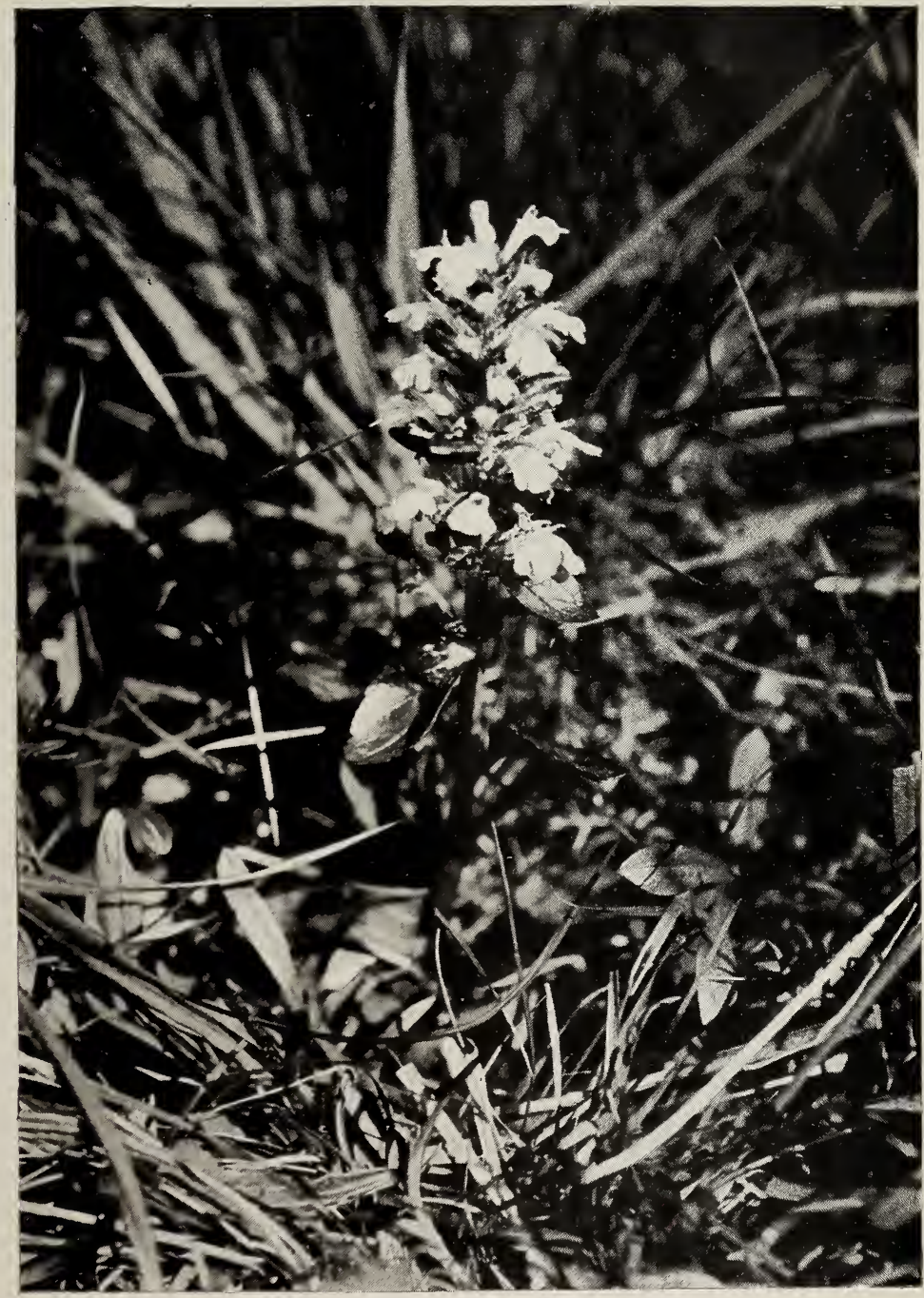

Common Bugle

(Ajuga reptars)

(Colour blue, rarely white) 


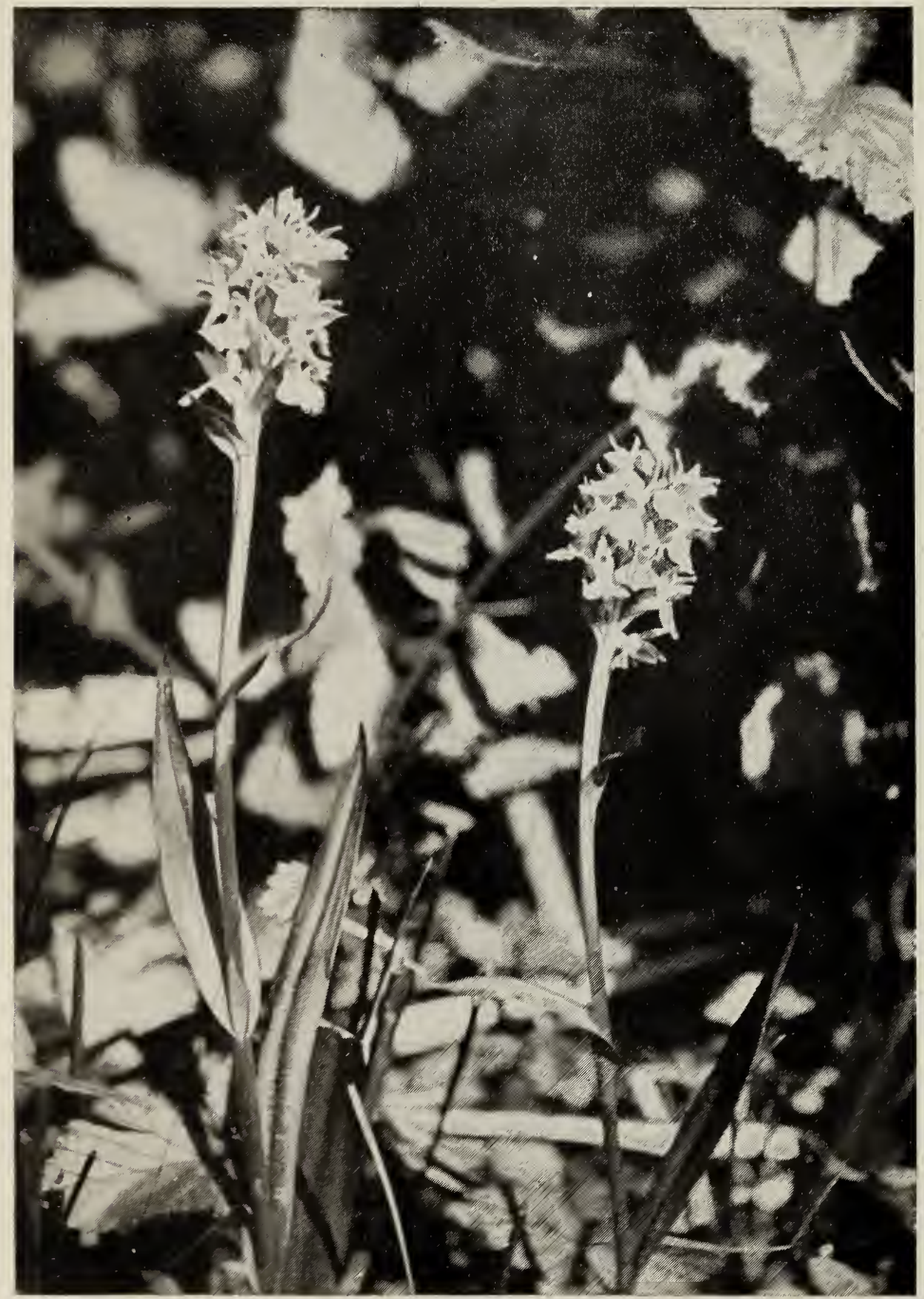

MAKSH ORCHIS

(Flower usually deep lilac or dull purple)
(Orchis latifolia)

Ord. Orchidea 


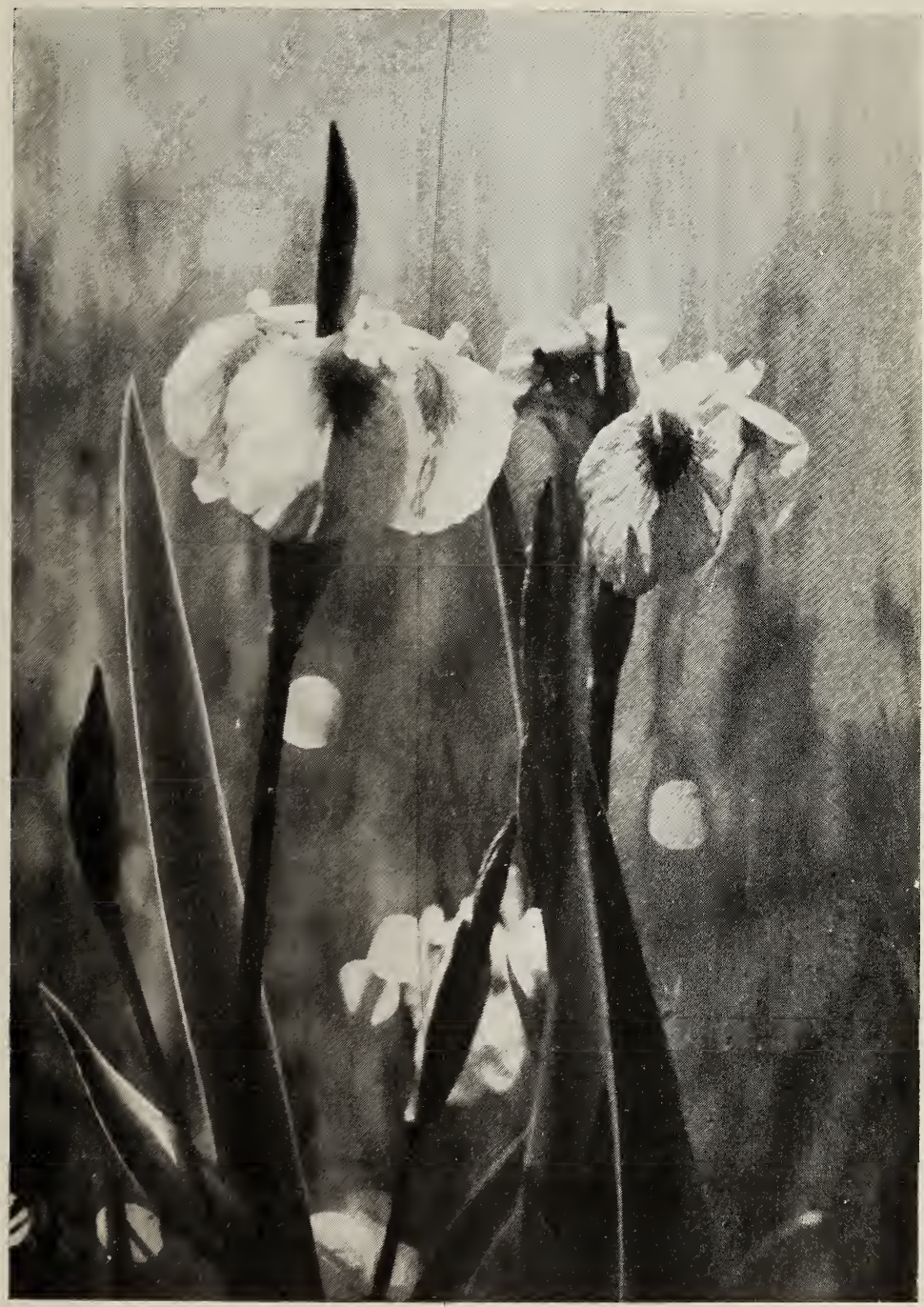

YelLOW IRIS

(Flower yellow)
(Iris Pseud-acorus)

Ord. Iridea 


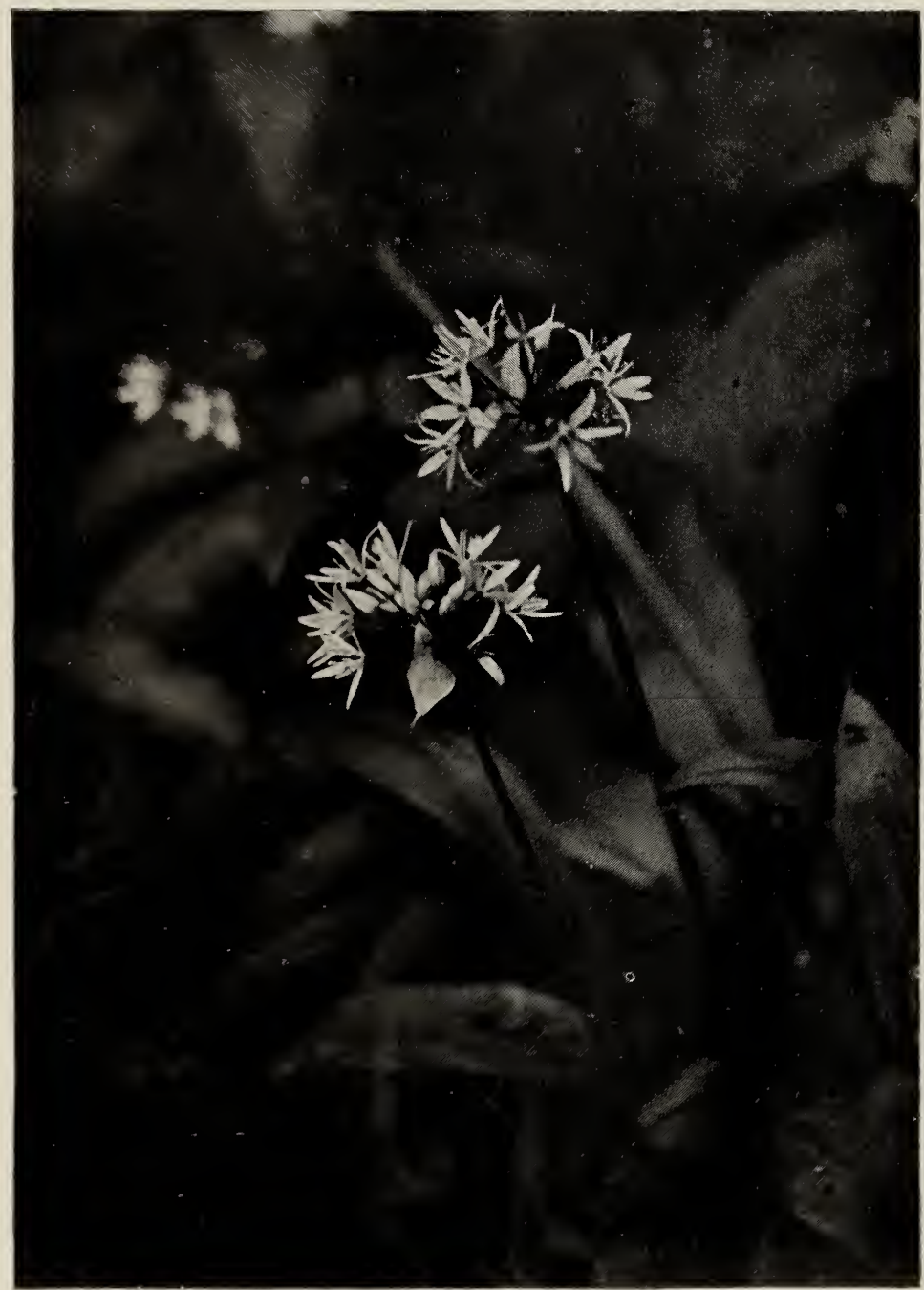

Broad-leaved Garlic or Ramsons (Flower white)
(Allium ursinum) Ord. Liliacece 


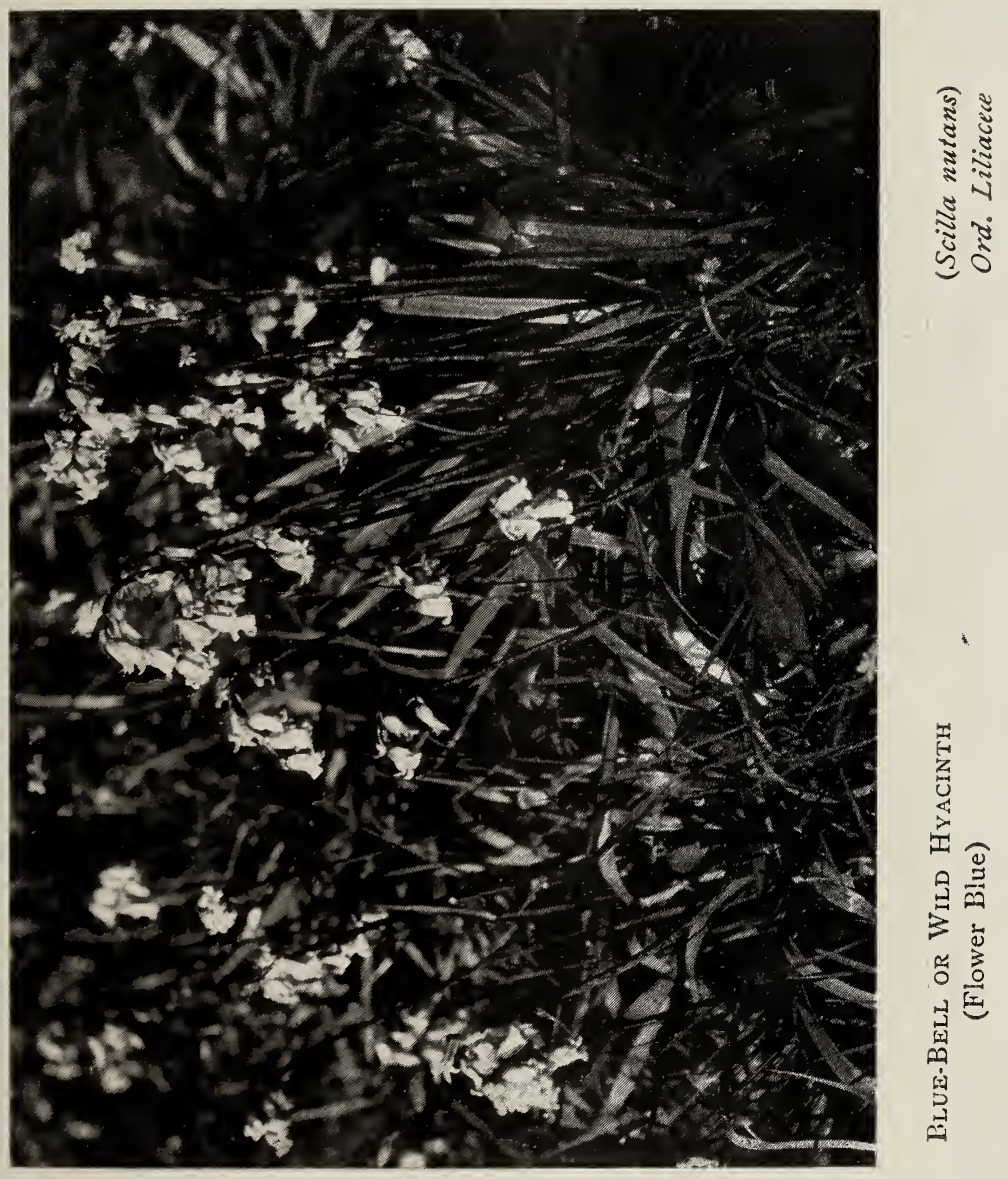




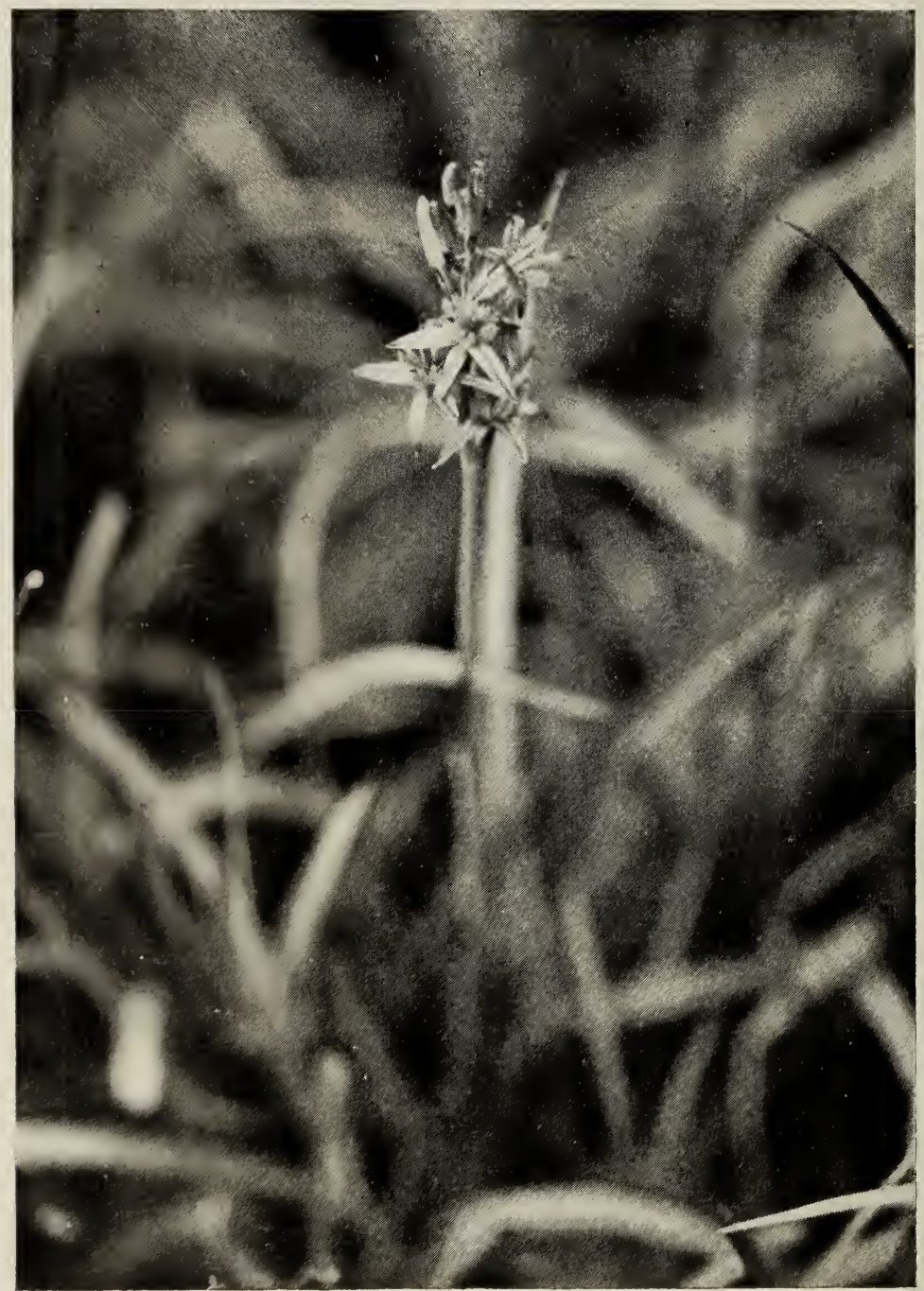

LANCASHiRe Bog Asphodel (Flower yellow)
(Narthecium ossifragum)

Ord. Liliacea 


\title{
Some Short Notes
}

\section{DESIGNED TO ASSIST THE READER IN IDENTIFYING THE FLOWERS}

\author{
ILLUSTRATED IN THIS VOLUME,
}

By ADAM L. GOWANS, M.A.

Warer Crowfoot (Frontispiece)-In our photograph the beholder looks down upon one of the ponds in which this easily distinguishable and beautiful flower with its floating leaves is found.

Great Spear-wort (Page 6)-Another aquatic plant. Its spearlike leaf, tall, hollow stem, and large, bright, yellow flower, two inches in diameter, resembling a gigantic buttercup, cannot be mistaken. The flower of the much smaller and commoner Lesser Spear-wort is about the size of a buttercup, from which its undivided leaf easily distinguishes it.

Upright Meadow Crowfoot or Buttercup, and Creeping Crowfoot (Pages 7 and 8)-There are several common species of crowfoot, all popularly known as 'buttercups.' The Creeping Buttercup may be distinguished by its long runners, Goldielocks by its bent.back calyx, and the Bulbous Crowfoot by its bulblike root.

The Marsh Marigold (Page q) is found only in wet places and is easily identified by its large golden-yellow flowers and roundish leaves shown in the photograph.

The Yellow Water-lily and White Water-lily (Pages ro and II) cannot be mistaken. A pond or lake where these immense flowers can be seen in all their glory is worth going miles to look at.

Water-cress (Page 12)-Found in water-courses. Should be identified without difficulty from the illustration. See the leaf (c.g., the good specimen in the very centre of the photograph) and the long wire-like pod.

The Lady's Smock (Page 13), Scurvy-grass (Page 15), and Heartsease (Page I6) are unmistakable.

The Charlock or Wild Mustard (Page r4), with its yellow flower, is so common in corn.fields that it is well-known to every one.

The rose-coloured Ragged Robin (Page 17 ) and Red Campion (Page I8) are often confused, but the tattered appearance of the former makes it easily distinguished on the slightest comparison of the two.

The fine photograph of the Greater Stitchwort (Page 19) should leave no doubt as to the flower it represents. The Lesser Stitchwort is very like it, but the petals are much more deeply cleft, and it is, therefore, more star-like in appearance. 
Meadow Crane's-bill (Page 20)-There are always two flowers on each peduncle of this handsome plant (see the buds in pairs). Here the companion-blossom has faded. This plant is very like the Wood Crane's-bill, but the diameter of the flower of the latter is about $3 / 4$ inch as compared with $11 / 4$ inch in the case of the former ; the pedicels of the latter are erect, of the former deflexed.

Herb-Robert (Page 2I)-The photograph of this pretty little plant (flower $1 / 2$ inch diameter, two on each peduncle) is a very clear one, and with careful study of the shape of the leaf, etc., it may be distinguished with certainty from other plants which resemble it, and which will be illustrated in later volumes.

Black Medick (Page 22)-This tiny little plant, with its small heads of yellow pea-shaped flowers, each only $1 / 8$ inch in diameter, is extremely like another very common flower, the Lesser Yellow Trefoil. The fruit is a certain means of identification; in the Niedick the pod is kidney-shaped, and ripens quite outside the c.alyx, which envelops the pod of the Lesser Trefoil as it ripens. Both plants are like the Hop Trefoil (Page 23) which has paler flowers in larger heads; the three may sometimes be found growing together, and if they are carefully compared, little points of difference will be found which make them easily distinguishable thereafter.

The pea-shaped yellow fiowers of the Bird's-foot Trefoil (Page 24), Greater Bird's-foot Trefoil (Page 25), and Meadow Vetchling (Page 27) are very familiar objects in the country. The greater trefoil is generally a larger plant, and more erect than the lesser. The two species can be distinguished by the two upper teeth of the calyx; in the greater trefoil they diverge, in the lesser they converge. The vetchling, so like the former to a careless observer, is easily distinguished by its leaves and tendrils, and by the different arrangement of the flowers in the heads (see the left hand corners of plates on pages 25 and 27 ).

The beautiful photographs of the Tufted Vetch (Page 26), clinging by its tendrils to a rose-bush, the Meadow-sweet (Page 28), the Common Avens (page 29), the Wild Strawberry (Page 30 ), the Marsh Cinquefoil (Page 3I), and the Silverweed (Page 33), are so clear that no further description is necessary.

The Tormentil (Page 32 (with its yellow flower of four (sometimes five) petals and pretty leaf is very common on dry pasture land. The Common Lady's Mantle (Page 34) is distinguished with certainty by its leaf from the other two species of Lady's Mantle.

The varieties of the Wild Rose are so numerous that they require special study to distinguish them. Of the Dog Rose (Page 35) alone, Hooker names 29 varieties.

The Wood Sanicle (Page 36 ) has so characteristic an appearance that it is easily recognised: most of the umbelliferæ, however, are difficult. The Cow-Parsnip (Page $3^{8}$ ) should be distinguished by its great size and rankness. Other plants resemble the Hemlock Water Dropwort (Page 37) to a greater or less extent, and careful note of the leaves, etc., is necessary. This plant is poisonous.

The flowers of the different kinds of Bedstraw give them a characteristic stamp. The common Smooth Heath Bedstraw (Page 40) 
does not exceed 6 inches in height, and is consequently unmistakable. The White Water Bedstraw (Page 39) has four to six leaves in a whorl. It is common in water-courses, while the Goose Grass (Page 4I) may be seen in every bedge. Most children know how the hispid stems and leaves cling to the clothes of the unsuspecting passer-by. Other species of Bedstraws will be illustrated in future volumes.

With careful attention to the leaves and colours of the flowers, there should be no difficulty whatever in recognising the Valerian (Page 42), Yarrow (Page 43), Mayweed (Page 44), Ox-Eye (Page 45), and Cat's-Ear (page 47).

The photograph of the Common Ragwort (Page ${ }_{4} 6$ ) is not so distinctive as is neçessary to show the difference between that plant and the Marsh Ragwort (Senecio Aquaticus), and might serve equally well for the latter. The Common Ragwort may be found everywhere, the Marsh Ragwort only in places beside water. The two plants may easily be found growing near one another, and the decided differences are evident on comparison and quite unmistakable. The flower-heads of the common variety are much denser, the petals narrower and the leaves much more indented.

I cannot pass the Marsh-Trefoil (Page 49)-though it cannot be mistaken for any other plant-without a word. This is one of the most beautiful of our native flowers, and a mass of its white blossoms in a pond or marsh is a sight to be remembered.

How many of us know the proper name of the familiar Ribwort Plantain (Page ${ }_{5}$ O), or of the Seaside Plantain (Page ${ }_{5} \mathrm{r}$ )?

The gorgeous colouring of the Yellow Toadilax (Page 52). and the peculiar appearance of the Knotted Figwort (Page 53), are sufficient for their identification.

The tall Foxglove (Page 54), the diminutive heliotrope-coloured Wild Thyme (Page 55), which is so common everywhere, as is the little Self-Heal (Page 56), present no difficulty, nor do the Skull-Cap (Page 57), the White Deadnettle (Page 58), the Bugle (Page 59), the appearance of each being quite characteristic.

The long slender pedicels of the Wood Loosestrife (Page 48) are sufficient to distinguish this plant.

There are several kinds of Orchis, which have a strong superficial resemblance to one another. Special study of text-books is necessary to distinguish them with absolute certainty. The Marsh Orchis (Page 6o) is only found in marshy places, and is usually richer in colour than the Early Purple Orchis and Spotted Palmate Orchis, which are also very common plants.

The illustrations leave no doubt of the identity of the Yellow Iris (Page 6I). Blue Bell (Page 63), Garlic (Page ' 62 ), and Bog Asphodel (Page 64). The strong odour of the Garlic alone would suffice to determine it at least. 


\section{Gowans's Nature Books.}

THE object of these little volumes ts to stimulate

a love of Nature and a desire to study it.

The first book of the series has been extremely successful, and the Publishers hope to make the others equally interesting and beautiful.

READY.

NO. 1.-WILD BIRDS AT HOME. SIXTY PHOTOGRAPHS FROM LIFE, BY CHAB. KIRK, OF BRITISH BIRDS AND THEIR NESTS.

NO. 2.-WILD FLOWERS AT MOME. FIRST SERIES. SIXTY PHOTOGRAPHE FROM NATURE, BY CAMERON TODD.

NO. 3.-WILD FLOWERS AT HOME. SECOND SERIES.

No. 4.-BUTTERFLIES AND MOTHS AT HOME. EIXTY PHOTOGRAPHS FROM LIFE, BY A. FORRESTER.

In Preparation.

NO. 5.-WILD BIRDS AT HOME. BECOND SERIES.

PRICE:

Parchment Cover, 6D. Net. Postage, 1D.

GOWANS \& GRAY, Ltd.,

35 Leicester Square, London, W.C.

58 Cadogan Street, Glasgow. 

-

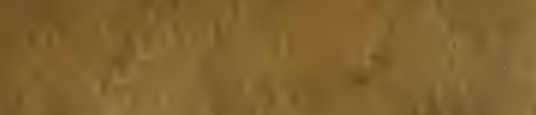

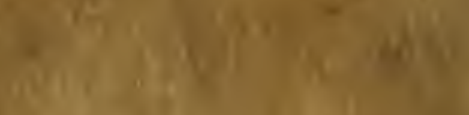

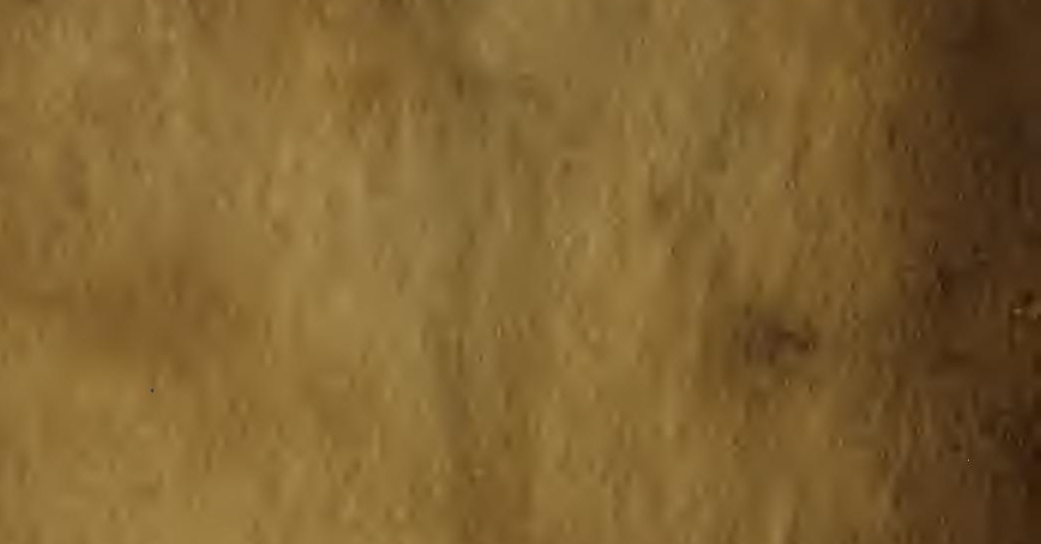

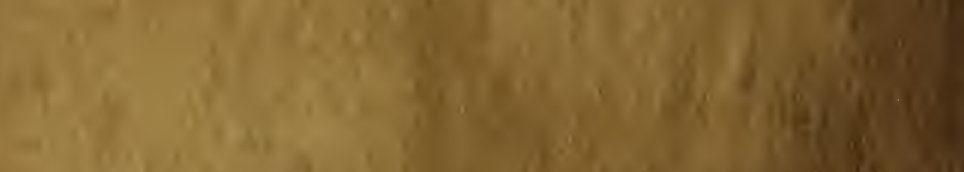

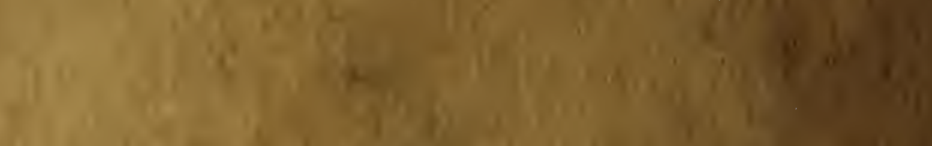

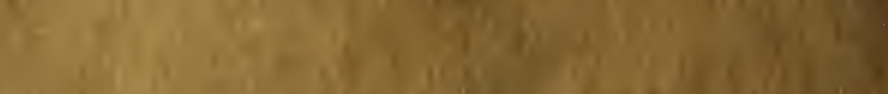

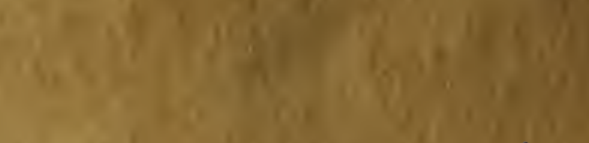

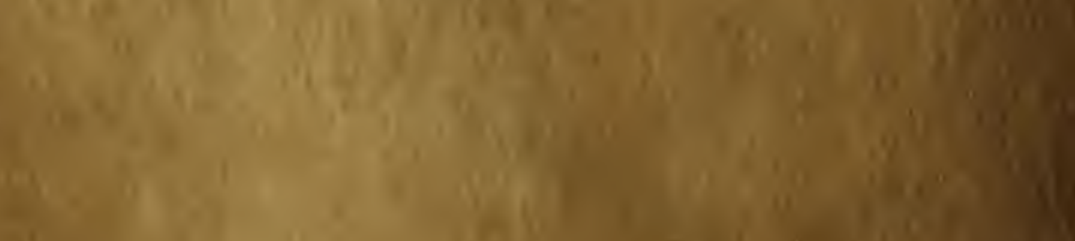
(1) 12 